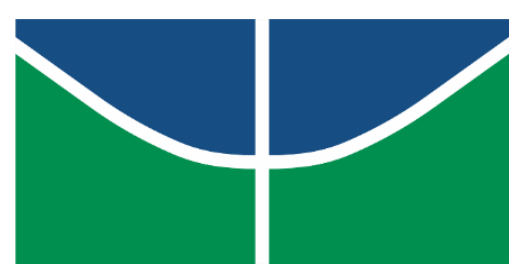

Universidade de Brasília

Instituto de Psicologia

Programa de Pós-graduação em Processos de Desenvolvimento Humano e Saúde

INDICADORES DO PERFIL PROFISSIONAL DO PSICÓLOGO ESCOLAR DAS EQUIPES ESPECIALIZADAS DE APOIO À APRENDIZAGEM DA SECRETARIA DE EDUCAÇÃO DO DF

Leonardo Vieira Nunes

Brasília, março de 2016 
Ficha catalográfica elaborada automaticamente, com os dados fornecidos pelo(a) autor(a)

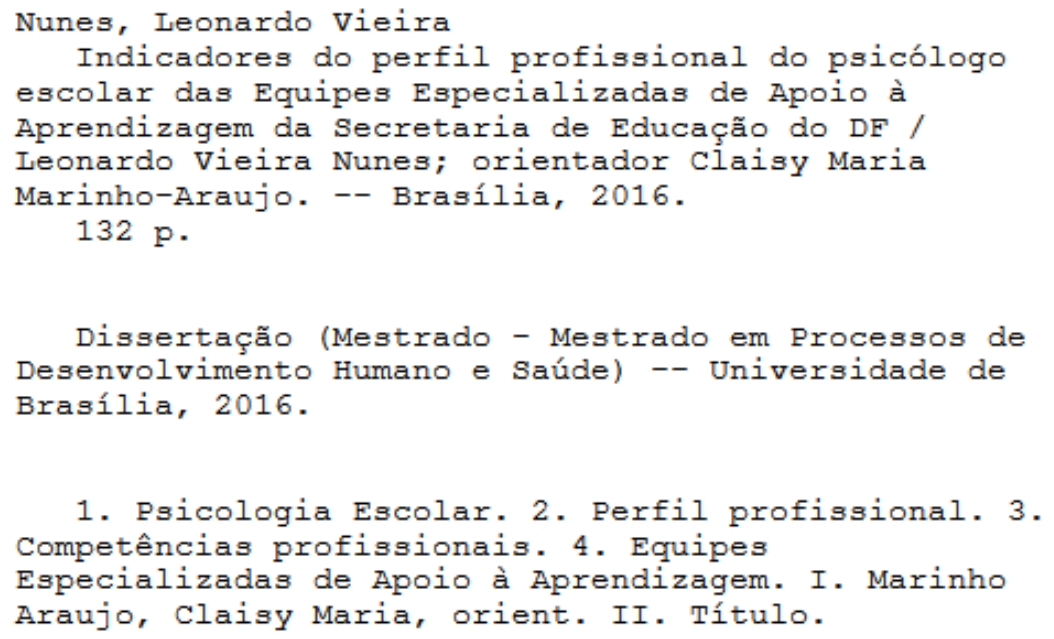



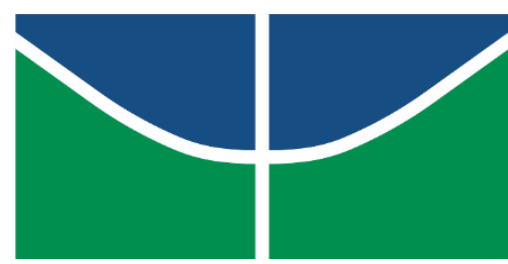

Universidade de Brasília

Instituto de Psicologia

Programa de Pós-graduação em Processos de Desenvolvimento Humano e Saúde

\title{
INDICADORES DO PERFIL PROFISSIONAL DO PSICÓLOGO ESCOLAR DAS EQUIPES ESPECIALIZADAS DE APOIO À APRENDIZAGEM DA SECRETARIA DE EDUCAÇÃO DO DF
}

\author{
Leonardo Vieira Nunes
}

Dissertação apresentada ao Instituto de Psicologia da Universidade de Brasília, como requisito parcial à obtenção do título de Mestre em Processos de Desenvolvimento Humano e Saúde, área de concentração Desenvolvimento Humano e Educação.

Orientação: Profa. Dra. Claisy Maria Marinho-Araujo 
Universidade de Brasília

Instituto de Psicologia

Programa de Pós-Graduação em Processos de Desenvolvimento Humano e Saúde

DISSERTAÇÃO APROVADA PELA SEGUINTE BANCA EXAMINADORA:

Profa. Dra. Claisy Maria Marinho-Araujo
Universidade de Brasília - Instituto de Psicologia
Presidente

Profa. Dra. Marisa Maria Brito da Justa Neves

Secretaria de Educação do DF

Membro Externo

Profa. Dra. Luciana de Oliveira Campolina

Centro Universitário de Brasília - UniCEUB

Membro Externo

Profa. Dra. Denise de Souza Fleith

Universidade de Brasília - Instituto de Psicologia

Suplente

Brasília, março de 2016 


\section{Agradecimentos}

A Deus, acima de tudo, por preencher a minha vida de bênçãos e de oportunidades de crescimento espiritual, moral, material e profissional. É a luz que me alimenta, o sol que aquece e impregna o meu coração de fé, otimismo e esperança na força do Bem.

A meus pais, pelo permanente incentivo ao meu desenvolvimento como ser humano. Cada um, da sua forma, colaborou profundamente para o meu o êxito nesse momento, especialmente pelos exemplos de honestidade e simplicidade que cultivam em suas ações. Vocês são partícipes dessa conquista e expresso meu reconhecimento por tudo o que representam em minha vida.

À professora Claisy, minha orientadora, por tudo! Por acreditar nas minhas potencialidades, mesmo quando eu próprio duvidava delas. Agradeço por sua generosidade em compartilhar os conhecimentos, afetos e experiências que me auxiliaram nessa trajetória acadêmica. Por ser uma referência e inspiração para o exercício da Psicologia Escolar, de forma compromissada, consciente e convicta. Não saberia, como de fato ainda não sei, agradecer o seu apoio em todos os momentos dessa caminhada. Muito obrigado!

Aos psicólogos escolares que participaram dessa pesquisa e contribuíram, de forma amistosa e interessada, com as reflexões e opiniões acerca dos temas propostos. Que possamos construir mais espaços de interlocução e desenvolvimento profissional.

À professora Marisa Brito, por participar desse momento tão importante na minha vida acadêmica. Agradeço por ter sido uma incentivadora do meu percurso na Psicologia Escolar desde o período da graduação e colaborado diretamente na minha formação profissional.

À professora Denise Fleith, por sua disponibilidade em ensinar, mesmo sem palavras. Seu exemplo de dedicação e cordialidade muito acrescentaram ao meu desenvolvimento pessoal e acadêmico. Obrigado por compartilhar seus conhecimentos nas atividades do Laboratório de Psicologia Escolar.

À professora Luciana Campolina, por aceitar prontamente o convite para participar da banca e colaborar com suas sugestões, críticas e provocações. Agradeço a parceria desse e de outros momentos em prol do desenvolvimento da Psicologia Escolar.

À Paula, minha esposa amada, pelo apoio incondicional e pelo incentivo constante ao longo desses dois anos. Obrigado por acreditar na minha capacidade e ser o sustentáculo afetivo e espiritual na minha vida.

À Patrícia, minha irmã amada, por me apoiar em todos os instantes dessa trajetória, especialmente nos momentos finais, renovando minhas energias e trabalhando, junto comigo, para o melhor desfecho desse trabalho. Obrigado por sua preocupação, pelas transcrições, pelas revisões, enfim, por estar próxima a mim. 
Ao Sérgio, meu cunhado, por sempre se colocar à disposição em colaborar. Agradeço o auxílio na transcrição das entrevistas.

Às minhas colegas do Laboratório de Psicologia Escolar, Lígia Libâneo, Rosana, Lígia Cavalcante, Liliene, Rosi, Marina e Rejane, por todos os momentos de aprendizado, de trabalho, de sorrisos e trocas afetivas que vocês compartilharam comigo. Sou grato por ter realizado essa etapa da minha vida com vocês.

Aos professores do PGPDS, por socializarem seus conhecimentos e experiências em prol da formação de tantos estudantes e da minha, em particular.

À Secretaria de Educação do DF, por possibilitar o afastamento para a realização deste estudo e por oferecer um campo fértil de pesquisa e crescimento profissional.

Aos psicólogos escolares do Gama e da Secretaria de Educação do DF, que cientes da minha escolha e do meu percurso no mestrado, foram incentivadores e parceiros na construção de espaços de interlocução e reflexão acerca das práticas profissionais.

Aos colegas de trabalho da EAPE, por se mostrarem tão engajados na formação continuada dos profissionais da SEDF e acreditarem ser possível, de forma intencional, promover transformações sociais e educacionais nos cenários em que vivemos. Agradeço o incentivo para a conclusão da dissertação e o apoio de cada um.

À Maria e Cláudia, secretárias do PED e do PGPDS, pela solicitude e disponibilidade permanentes.

À Universidade de Brasília, por ser pública, gratuita e de muita qualidade. Tenho orgulho de ter cursado a graduação e o mestrado nesta instituição. 


\section{Resumo}

A atuação do psicólogo escolar na rede pública de ensino do Distrito Federal (DF) tem requerido o desenvolvimento de competências para a construção de um perfil profissional que considere a complexidade do fenômeno educativo e a dinamicidade do contexto escolar. Ao psicólogo é exigido o desenvolvimento de competências teóricas, técnicas, éticas, interpessoais, pessoais e estéticas que privilegiem uma atuação mais ampla na instituição escolar, considerando a diversidade de ações que podem ser realizadas por esse profissional. $\mathrm{O}$ interesse em conhecer, de forma aprofundada, esse perfil levou à realização dessa pesquisa que teve por objetivo investigar os indicadores do perfil profissional de psicólogos escolares que trabalham nas Equipes Especializadas de Apoio à Aprendizagem (EEAA) da Secretaria de Educação do DF (SEDF). Foram realizadas entrevistas individuais com 25 psicólogos escolares que atuavam na EEAA, em 13 cidades do DF, visando a investigação do perfil e das competências profissionais necessárias à atuação no serviço. As informações recolhidas foram organizadas e analisadas a partir dos fundamentos da perspectiva histórico-cultural do desenvolvimento humano e da Psicologia Escolar contemporânea. As questões formuladas na entrevista originaram resultados que foram analisados a partir da circulação de sentidos e significados produzidos pelos participantes acerca das competências profissionais do psicólogo escolar da EEAA. Os indicadores resultantes dessa análise mostraram que os psicólogos possuem clareza acerca do perfil esperado para atuar na EEAA e da necessidade de desenvolver e consolidar competências profissionais sugeridas pela Orientação Pedagógica (OP/2010). Os participantes relataram que, para ser psicólogo na EEAA, é importante, entre outros aspectos, ter: conhecimento de psicologia do desenvolvimento, apropriação da abordagem histórico-cultural, compromisso com o estudo e a formação continuada, apropriação da atuação institucional e coletiva, desenvolvimento da escuta psicológica, domínio da avaliação psicológica, capacidade para construir relacionamentos interpessoais favoráveis à atuação profissional, empatia, clareza na comunicação, respeito aos atores educacionais, responsabilidade com o uso do sigilo e criatividade. Esses e outros indicadores favoreceram a elaboração de uma proposta de perfil profissional apresentada como conclusão da pesquisa. Como desdobramento dessa investigação, espera-se que os conhecimentos construídos colaborem com o aprimoramento das práticas dos psicólogos escolares integrantes da Equipe Especializada de Apoio à Aprendizagem da SEDF. Esperase, ainda, que os indicadores apresentados orientem a formação inicial e continuada do psicólogo por meio da formulação e implementação de desenhos formativos que contemplem o perfil e as competências profissionais esperadas do psicólogo escolar, seja em nível público ou privado.

Palavras-chave: Psicologia Escolar; perfil profissional; competências profissionais. 


\begin{abstract}
The role of the school psychologist in the public schools of the Distrito Federal (DF) has required the development of skills to build a professional profile that considers the complexity of the educational phenomenon and the dynamicity of the school context. It requires the psychologist to develop theoretical technical, ethical, interpersonal, personal and aesthetic competencies that favor a wider role in schools, considering the diversity of actions that can be performed by this professional. The interest in knowing in depth this profile led to this research, which aims to investigate the professional profile of indicators of school psychologists who work in Equipes Especializadas de Apoio à Aprendizagem (EEAA) from the Secretaria de Educação do DF (SEDF). Individual interviews were held with twentyfive school psychologists who worked in EEAA, in 13 cities of the Distrito Federal, in order to research the necessary profile and professional skills to perform their roles. The information gathered was organized and analyzed from the foundations of cultural-historical perspective of human development and the Contemporary Educational Psychology. The questions asked in the interview gave results that were analyzed from the circulation of senses and meanings produced by the participants about the professional competencies of the school psychologist of EEAA. Indicators resulting from this analysis showed that psychologists have clarity about the expected profile to act in the EEAA as well as the need to develop and consolidate professional competencies suggested by the educational guidelines Orientação Pedagógica (OP/2010). Participants reported that to be a psychologist in EEAA, it is important to have the knowledge about developmental psychology, appropriation of historical-cultural approach, commitment for the study and continuing education, appropriation of institutional and collective performance, development of psychological listening, control of psychological evaluation, ability to build interpersonal relationships conducive to professional practice, empathy, clear communication, respect for educational actors, creativity and responsibility related to the use of secrecy. These and other indicators favor the development of a proposal of professional profile presented as a conclusion of the research. As an outcome of this research it is hoped that the built knowledge collaborates for the improvement of the practices of school psychologists members of Equipes Especializadas de Apoio à Aprendizagem (EEAA) from SEDF. It is also hoped that the indicators presented guide the initial and continuing training of psychologists through the formulation and implementation of training designs that include the profile and professional competencies expected for the school psychologist, both in public and private levels.
\end{abstract}

Keywords: School psychology; professional profile; professional competencies. 


\section{Sumário}

Agradecimentos $\quad$ V

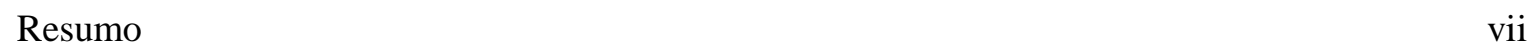

Abstract viii

\begin{tabular}{lc} 
Lista de Tabelas & X \\
\hline
\end{tabular}

$\begin{array}{lc}\text { Lista de Figuras } & \text { xi }\end{array}$

Capítulo 1 - Introdução 11

Capítulo 2 - A Psicologia Escolar no Brasil: As Contribuições do Grupo de Trabalho de Psicologia Escolar e Educacional da ANPEPP 4

A Psicologia Escolar e o papel do psicólogo: Contribuições nacionais e internacionais $\quad 45$

Capítulo 3 - Desenvolvimento Humano e Perfil Profissional 56

$\begin{array}{lr}\text { Capítulo 4- Metodologia } & 65\end{array}$

$\begin{array}{ll}\text { Objetivos } & 65\end{array}$

$\begin{array}{ll}\text { Objetivo geral } & 65\end{array}$

$\begin{array}{ll}\text { Objetivos específicos } & 65\end{array}$

Pressupostos teórico-metodológicos $\quad 65$

$\begin{array}{ll}\text { Contexto de pesquisa } & 69\end{array}$

Aspectos históricos da Psicologia Escolar na SEDF $\quad 71$

A Psicologia Escolar na SEDF nos dias de hoje $\quad 74$

$\begin{array}{ll}\text { Participantes } & 76\end{array}$

Procedimentos de construção e recolha das informações $\quad 79$

$\begin{array}{ll}\text { Entrevistas com os psicólogos escolares } & 79\end{array}$

Procedimento de análise das informações $\quad 80$

Capítulo 5 - Discussão e Resultados 82

Capítulo 6-Considerações Finais 105

$\begin{array}{ll}\text { Referências } & 115\end{array}$

$\begin{array}{lr}\text { Anexos } & 126\end{array}$ 


\section{Lista de Tabelas}

Tabela 1 Psicologia Escolar: Pesquisa, Formação e Prática 6

Tabela 2 Psicologia Escolar: LDB e Educação Hoje 10

Tabela $3 \quad$ Psicologia Escolar e Educacional: Saúde e Qualidade de Vida 13

Tabela 4 Psicologia Escolar: Ética e Competências na Formação e Atuação $\begin{array}{ll}\text { Profissional } & 17\end{array}$

Tabela $5 \quad$ Psicologia Escolar e Compromisso Social 23

Tabela $6 \quad$ Formação em Psicologia Escolar: Realidades e Perspectivas 28

Tabela 7 Psicologia Escolar: Novos Cenários e Contextos de Pesquisa, Formação e Prática 32

Tabela $8 \quad$ Psicologia Escolar: Identificando e Superando Barreiras 36

Tabela 9 Psicologia Escolar: Desafios e Bastidores na Educação Pública 41

Tabela 10 Psicologia Escolar: Pesquisa e Intervenção 46

Tabela 11 Quantitativo de Psicólogos Escolares por Coordenação Regional de $\begin{array}{ll}\text { Ensino } & 75\end{array}$

$\begin{array}{lll}\text { Tabela } 12 \text { Caracterização dos Participantes } & 78\end{array}$

Tabela 13 Indicadores de Competências Teóricas, Científicas e Metodológicas

82

Tabela $14 \quad$ Indicadores de Competências Técnicas e Práticas 86

Tabela 15 Indicadores de Competências Sociais, Pessoais e Interpessoais 95

Tabela 16 Indicadores de Competências Éticas e Estéticas 98

Tabela 17 Principais Indicadores de Perfil Profissional dos Psicólogos Escolares das EEAA 106 


\section{Lista de figuras}

Figura 1 Linha Histórica da Psicologia Escolar na SEDF 



\section{Capítulo 1 \\ Introdução}

A atuação do psicólogo escolar e suas práticas profissionais têm sido objeto de estudo de diversos pesquisadores da área (Barbosa, 2008; Bisinoto \& Marinho-Araujo, 2014; Cavalcante \& Aquino, 2013; Chagas \& Pedroza, 2013; Cruces, 2005; Facci \& Souza, 2011; Fleith, 2009, 2011; Guzzo, 2005, 2006; Lara, 2014; Lessa \& Facci, 2009; Libâneo, 2015; Marinho-Araujo, 2003, 2010a, 2010b, 2014; Marinho-Araujo \& Almeida, 2005; Mitjáns Martínez, 2009, 2010; Moreira \& Guzzo, 2014; Neves, 2011; Oliveira, 2011; Oliveira \& Marinho-Araujo, 2009; Petroni, 2013; Petroni \& Souza, 2014; Sampaio, 2009; Silva, 2015; Souza, 2009). As discussões nesses e em outros trabalhos têm abordado as ações que podem ser desenvolvidas pelo psicólogo que ocupa os espaços educativos; porém, poucos relacionam, de forma explícita, as intervenções desse profissional à construção de um perfil profissional que considere as diversas competências a serem desenvolvidas.

Ao se compreender a diversidade e a constante transformação dos contextos em que atua o psicólogo escolar, entende-se que o perfil profissional não deve ser visto de forma estática, cumulativa e estritamente relacionada à realização das tarefas. Diversos processos de mediações são vivenciados no cotidiano da profissão e a própria profissão reconfigura-se, na medida em que os atores envolvidos reconstroem as relações e as produções materiais associadas a esses saberes e práticas. Nesse processo dinâmico e histórico, no qual desenvolvimento pessoal e profissional se constituem dialeticamente, o perfil profissional está em constante transformação e atualização.

A construção desse perfil exige a produção de novos conhecimentos e a ressignificação daqueles já compreendidos, provocando o desenvolvimento de competências mais eficazes para lidar com as situações desafiadoras enfrentadas pelo psicólogo escolar (Marinho-Araujo, 2007). Estudar o perfil profissional do psicólogo escolar e as competências necessárias à atuação se mostram relevantes para, no campo teórico, produzir conhecimentos na área da Psicologia Escolar e colaborar para o desenvolvimento da ciência psicológica; e, no campo prático, impactar a atuação dos profissionais da área, propondo atualizações das práticas instituídas, além de possibilitar o debate e reflexão acerca do desenvolvimento das competências profissionais.

Especificamente no Distrito Federal, a Psicologia Escolar na rede pública atravessou diversas mudanças desde o surgimento do serviço na década de 1970, passando por transformações teóricopráticas relacionadas à formação, atuação e perfil do psicólogo escolar. Ao longo desses anos, esse perfil foi se alterando, na medida em que novas concepções acerca do que fazer e como fazer foram construídas pelos psicólogos escolares, que modificaram suas práticas e a forma como entendiam a atuação em Psicologia Escolar. 
Após a publicação da Orientação Pedagógica ${ }^{1}$ do Serviço Especializado de Apoio à Aprendizagem, em 2010 (GDF, 2010), novas diretrizes de atuação foram implementadas no sentido de nortear as práticas profissionais dos psicólogos escolares, pautadas em uma Psicologia Escolar comprometida com a realidade social e com a instituição escolar. Surgiu, desde então, a necessidade de se (re)conhecer e atualizar o perfil profissional dos psicólogos das Equipes Especializadas de Apoio à Aprendizagem (EEAA) da Secretaria de Educação do DF (SEDF), diante das mudanças paradigmáticas, conceituais e institucionais promovidas com a publicação da diretriz, bem como pelas contribuições teóricas encontradas na literatura científica (Barbosa, 2008; GDF, 2010; Guzzo, 2005, 2006; Libâneo, 2015; Marinho-Araujo, 2003, 2010b, 2014; Marinho-Araujo \& Neves, 2007; Marinho-Araujo, Neves, Penna-Moreira \& Barbosa, 2011; Medeiros \& Aquino, 2011; Neves, 2001; Penna-Moreira, 2007; Silva, 2015).

O contexto de atuação dos psicólogos escolares no sistema público de ensino do DF é bastante favorável ao exercício profissional, uma vez que há o reconhecimento, a legalização e a institucionalização desse profissional na Secretaria de Educação do Distrito Federal (SEDF). As demandas direcionadas ao psicólogo escolar consideram a complexidade do fenômeno educativo e das relações estabelecidas no cotidiano escolar, o que exige o desenvolvimento de competências e a construção do perfil profissional que contemplem essas questões.

Como psicólogo escolar nesse contexto, lidando com os desafios da prática profissional, da realidade de cada instituição de ensino em que eu trabalhava e dos meus estudos, que acompanhavam a própria construção de conhecimento em Psicologia Escolar, considerei a realização do mestrado acadêmico como uma oportunidade para aprofundar estudos e refletir acerca do perfil profissional dos psicólogos da EEAA. Fui aprovado na seleção do Programa de Pós-graduação em Processos de Desenvolvimento Humano e Saúde, da UnB, para cursar o mestrado acadêmico a partir de 2014.

Estudei Psicologia na Universidade de Brasília, concluí o curso no ano de 2003 e ingressei na Secretaria de Educação do DF em 2007. Desde a admissão no curso de graduação tinha a certeza de que a escolha de atuação profissional seria o campo da Psicologia Escolar; assim, meus estudos e estágios foram direcionados para esse campo de conhecimentos. Em uma área de atuação predominantemente feminina, causava estranhamento a outros estudantes de Psicologia o fato de um provável psicólogo ter tanta convicção de sua escolha profissional. E é essa convicção que me move até esse momento!

$\mathrm{O}$ interesse em pesquisar o perfil profissional dos psicólogos escolares das Equipes Especializadas de Apoio à Aprendizagem surgiu da aproximação com o campo e da experiência que tive como psicólogo escolar durante oito anos, atuando nessas equipes multiprofissionais. No ano de

\footnotetext{
${ }^{1}$ A Orientação Pedagógica do Serviço Especializado de Apoio à Aprendizagem é o documento normatizador que apresenta as diretrizes técnicas e pedagógicas para a atuação dos profissionais que compõem as Equipes Especializadas de Apoio à Aprendizagem, no âmbito da Secretaria de Estado de Educação do Distrito Federal. Nesse trabalho, esse documento será designado como OP/2010.
} 
2014, após ingressar no mestrado, recebi convite para integrar a equipe da EAPE (Escola de Aperfeiçoamento dos Profissionais da Educação da SEDF), tornando-me responsável pela articulação, elaboração e implementação de propostas formativas para os psicólogos escolares e pedagogos do Serviço Especializado de Apoio à Aprendizagem. Esse percurso profissional e acadêmico, além de justificar o interesse temático desta pesquisa, atesta a relevância profissional em se empreender uma investigação que objetive apresentar contribuições à construção identitária do psicólogo escolar da EEAA.

A respeito da relevância científica e social desta pesquisa, espera-se que a produção de conhecimento acerca do perfil e das competências profissionais do psicólogo escolar amplie o escopo teórico e conceitual do tema e influenciem a construção e implementação de políticas públicas nas áreas de Educação e da Psicologia. A inserção e o reconhecimento profissional do psicólogo na rede pública de ensino, a formulação e a reformulação da legislação brasileira e regional acerca do perfil e dos papéis desse profissional nas instituições e a elaboração de propostas de formação inicial e continuada dos psicólogos são exemplos de como esse trabalho pode impactar o desenvolvimento de pesquisas futuras e de ações políticas e legais com base no perfil profissional.

Esta dissertação foi organizada em cinco capítulos. O primeiro capítulo apresenta a produção da literatura científica brasileira na área de Psicologia Escolar, utilizando as contribuições da produção do Grupo de Trabalho de Psicologia Escolar e Educacional da Associação Nacional de Pesquisa e Pósgraduação em Psicologia (ANPEPP). São evidenciados os livros desse GT e os capítulos relacionados ao tema dessa pesquisa.

O segundo capítulo discorre acerca dos pressupostos teóricos-epistemológicos que subsidiam a compreensão do desenvolvimento humano e do perfil profissional do psicólogo escolar. Enfocam-se as bases conceituais da perspectiva histórico-cultural do desenvolvimento humano e da Psicologia Escolar contemporânea.

O terceiro capítulo elucida a metodologia e os referenciais teórico-metodológicos que orientaram a investigação. São apresentados o contexto e os participantes do estudo, explicando os procedimentos de construção, interpretação e análise das informações recolhidas no campo de pesquisa.

O quarto capítulo é dedicado à apresentação e à discussão dos resultados. São analisados os indicadores de perfil profissional referidos nas entrevistas com os psicólogos escolares.

O quinto e último capítulo apresenta as considerações finais, evidenciando as sínteses alcançadas, os desdobramentos da pesquisa e as sugestões de investigações futuras. Ao final do trabalho, são relacionadas as referências bibliográficas e os anexos. 


\section{Capítulo 2}

\section{A Psicologia Escolar no Brasil: As Contribuições do Grupo de Trabalho de Psicologia Escolar e Educacional da ANPEPP}

A Psicologia Escolar, caracterizada como campo de pesquisa, atuação e produção de conhecimento, tem sido objeto de estudos que focam alguns papéis e intervenções que podem ser desenvolvidas pelo psicólogo escolar (Anache, 2009; Cruces, 2005; Fleith, 2009, 2011; Guzzo, 2005; Guzzo, Moreira \& Mezzalira, 2011; Marinho-Araujo, 2003, 2014; Marinho-Araujo \& Almeida, 2005; Marinho-Araujo \& Neves, 2007; Mitjáns Martínez, 2009, 2010; Neves, 2009; Neves \& Almeida, 2003; Sant'Ana \& Guzzo, 2014, Souza, Petroni, Dugnani, Barbosa \& Andrada, 2014). Essas contribuições têm sido divulgadas por meio de artigos científicos, livros, teses, dissertações, relatos de experiências e outras produções de conhecimento que favorecem o desenvolvimento e consolidação da área de Psicologia Escolar.

No Brasil, dentre as produções acadêmicas relacionadas à área, destacam-se aquelas realizadas pelo Grupo de Trabalho (GT) de Psicologia Escolar e Educacional da Associação Nacional de Pesquisa e Pós-graduação em Psicologia (ANPEPP), que, desde 1994, vem fomentando discussões sobre pesquisa, política e formação na área de Psicologia Escolar. As reuniões do GT acontecem bianualmente e o último encontro ocorreu em 2014, na cidade de Bento Gonçalves/RS. Naquela ocasião, foi realizado o XV Simpósio de Pesquisa e Intercâmbio Científico da ANPEPP que contou com 68 GTs, representando diversas áreas da ciência psicológica, cujo objetivo foi o de desenvolver o mais elevado fórum de discussão da produção em Psicologia no Brasil.

As ações do GT de Psicologia Escolar e Educacional envolvem publicações conjuntas, intercâmbios institucionais, participação em eventos científicos, projetos, parcerias na formação de novos pesquisadores e outras iniciativas. O GT, na sua composição em 2016, tem como membros 18 professores, que atuam em 11 diferentes Instituições de Ensino Superior, localizadas em sete estados brasileiros e no Distrito Federal, o que demonstra a diversidade e a representatividade de pesquisadores que compõem o Grupo de Trabalho. Além disso, participam do GT de Psicologia Escolar/Educacional doutorandos vinculados aos programas de pós-graduação nos quais atuam os membros efetivos, possibilitando a integração com os demais pesquisadores da área. Essa vinculação estimula a continuidade nas pesquisas e a inserção desses doutorandos nos diversos estudos interinstitucionais, organizados pelos professores pesquisadores do GT.

Uma das principais produções do GT são as publicações conjuntas, organizadas em coletânea de livros, que têm favorecido a visibilidade, os avanços e as contribuições da Psicologia Escolar aos contextos de atuação, de pesquisa e de formação profissional. A publicação e divulgação dessas obras, junto a outras iniciativas do GT (ANPEPP, 2012), tem por finalidade: (a) impactar processos de formação inicial e continuada de profissionais da área; (b) influenciar a produção de conhecimento e de pesquisas na área e na prática profissional dos psicólogos escolares; (c) discutir desdobramentos e 
implicações da expansão da área, por meio de novos desenhos na formação ou de diversificadas perspectivas de atuação profissional; (e) avaliar quais as novas demandas de produção de conhecimento para a Psicologia Escolar; (f) examinar as perspectivas de inserção da Psicologia Escolar em políticas públicas, como articulação de ações conjuntas de pesquisa e de formação profissional; (g) debater sobre os processos de avaliação institucional da área; (h) refletir sobre a produção científica dos participantes e suas contribuições ao aprimoramento da formação e do compromisso social dos psicólogos que trabalham nos contextos educativos; e (i) avaliar a implantação das Diretrizes Curriculares Nacionais para Psicologia Escolar e Educacional (ANPEPP, 2012).

Considerando a abrangência, historicidade e representatividade das produções do GT de Psicologia Escolar e Educacional da ANPEPP, bem como as temáticas dessas produções, bastante correlatas aos objetivos desta pesquisa, foram adotadas essas referências como suporte principal à revisão de literatura da presente pesquisa. Assim, o objetivo deste capítulo é apresentar as produções coletivas do Grupo de Trabalho de Psicologia Escolar da ANPEPP, com destaque para os capítulos que se relacionam com a atuação do psicólogo escolar e a caracterização do seu perfil profissional. Dada a diversidade de temas explorados pelos autores, buscou-se evidenciar aqueles que abordam aspectos ligados às atribuições, funções, papéis e responsabilidades do psicólogo escolar, a fim de compreender os elementos ou características que influenciam a construção do seu perfil profissional.

Serão apresentados os livros publicados pelo GT de Psicologia Escolar e Educacional da ANPEPP e, em seguida, realizadas reflexões teóricas acerca dos temas citados. Na sequência cronológica e histórica, as publicações do GT, até o presente momento, são as seguintes:

1. Weschler, S. (Ed.). (1996). Psicologia Escolar: Pesquisa, formação e prática. Campinas: Alínea.

2. Guzzo, R. S. L. (Ed.). (1999). Psicologia Escolar: LDB e educação hoje. Campinas: Alínea.

3. Del Prette, Z.A P. (Ed.). (2001). Psicologia Escolar e Educacional: Saúde e qualidade de vida. Campinas: Alínea.

4. Almeida, S.F.C. (Ed.). (2003). Psicologia Escolar: Ética e competências na formação profissional. Campinas: Alínea.

5. Mitjáns Martínez, A. (Ed.). (2005). Psicologia Escolar e compromisso social: Novos discursos, novas práticas. Campinas: Alínea.

6. Campos, H. R. (Ed.). (2007). Formação em Psicologia Escolar: Realidades e perspectivas. Campinas: Alínea.

7. Marinho-Araujo, C. M. (Ed.). (2009). Psicologia Escolar: Novos cenários e contextos de pesquisa, formação e prática. Campinas: Alínea.

8. Guzzo, R. S. L., \& Marinho-Araujo, C. M. (2011). Psicologia Escolar: Identificando e superando barreiras. Campinas: Alínea. 
9. Guzzo, R. S. L. (Ed.). (2014). Psicologia Escolar: Desafios e bastidores na Educação Pública. Campinas: Alínea.

A seguir, serão apresentadas as informações referentes ao livro Psicologia Escolar: Pesquisa, Formação e Prática (1996), organizado por Solange Múglia Wechsler, que se encontra na $4^{\text {a }}$ edição. Destacar-se-ão alguns capítulos para análise acerca do perfil e das competências profissionais do psicólogo escolar.

Tabela 1

Psicologia Escolar: Pesquisa, Formação e Prática

\begin{tabular}{|c|c|c|c|}
\hline \multicolumn{2}{|r|}{ CAPÍTULO } & \multirow{2}{*}{$\operatorname{AUTOR}(\mathrm{ES})$} & \multirow{2}{*}{ SÍNTESE } \\
\hline $\mathbf{N}^{\mathbf{o}}$ & TÍTULO & & \\
\hline 1 & $\begin{array}{l}\text { As origens e o } \\
\text { desenvolvimento da } \\
\text { Psicologia Escolar }\end{array}$ & $\begin{array}{l}\text { Samuel Pfromm } \\
\text { Netto }\end{array}$ & $\begin{array}{l}\text { Apresenta as origens e o desenvolvimento da } \\
\text { Psicologia Escolar, por meio de relato histórico } \\
\text { de seu nascimento e crescimento em países } \\
\text { como Estados Unidos, Grã-Bretanha, Suíça, } \\
\text { Bélgica, Alemanha, Itália, França e destaca seu } \\
\text { surgimento no Brasil, refletindo sobre as } \\
\text { influências recebidas pela área. }\end{array}$ \\
\hline 2 & $\begin{array}{l}\text { Pesquisa em } \\
\text { Psicologia Escolar }\end{array}$ & $\begin{array}{l}\text { Geraldina Porto } \\
\text { Witter }\end{array}$ & $\begin{array}{l}\text { Apresenta uma revisão bibliográfica de } \\
\text { pesquisas realizadas nos últimos dez anos, com } \\
\text { análise de dissertações e teses da USP, } \\
\text { PUCCAMP e UNICAMP. Destaca a realidade } \\
\text { da Psicologia Escolar em nosso país e salienta a } \\
\text { necessidade de os psicólogos terem uma boa } \\
\text { formação em pesquisa, aproveitando a vida } \\
\text { cotidiana e o uso da criatividade para essa } \\
\text { realização. }\end{array}$ \\
\hline
\end{tabular}

3 Perspectivas para o Maria Helena futuro da Psicologia Novaes Escolar
Analisa o papel do psicólogo e os desafios colocados ao desenvolvimento da área, destacando a importância da autonomia do psicólogo e do reconhecimento social da profissão. Em meio a um mundo em transformações e desenvolvimento tecnológico, ressalta o compromisso social da Psicologia Escolar frente a essas mudanças.
4 Formando psicólogos Raquel Souza escolares no Brasil: $\quad$ Lobo Guzzo Dificuldades e perspectivas
Discute as expectativas e dificuldades da formação de psicólogos escolares no Brasil, relacionado esse debate ao currículo, à ausência de modelos de ação profissional específicos do Brasil e de padrões éticos e profissionais conhecidos pela comunidade. Destaca o papel das Universidades, Conselhos de Psicologia e Associações Profissionais no desenvolvimento da profissão do país. 
5 Padrões e práticas das Solange Múglia associações internacionais em Psicologia Escolar

Wechsler
Apresenta informações sobre uma pesquisa realizada junto às Associações Internacionais de Psicologia Escolar/Educacional, visando comparar as experiências e delinear estratégias de atuação úteis à realidade brasileira. Destaca a importância de se recuperar a história da Psicologia Escolar no país e a busca de caminhos para uma melhor qualificação profissional dos psicólogos.

Maria Helena Novaes

Destaca a transdisciplinaridade na formação do psicólogo escolar e a multiplicidade de linguagens descritivas, interpretativas e simbólicas relacionadas aos fenômenos sociais. Aponta lacunas na formação, desafios e perspectivas a serem pensados para a atuação do psicólogo.

\section{Habilidades} envolvidas na atuação do psicólogo escolar/educacional
Zilda Aparecida

Pereira Del Prette

\& Almir Del Prette

Discute a profissionalização do psicólogo escolar no contexto escolar brasileiro, situando o desenvolvimento de determinadas habilidades como uma das dimensões de requisitos necessárias ao atendimento das demandas educacionais e à consolidação da identidade profissional na área.

8 Avaliação das dificuldades de aprendizagem: Novas perspectivas para a avaliação psicoeducacional

\section{Eda Marconi} Custódio

Propõe uma reflexão acerca de como se processa a avaliação psicológica de crianças com dificuldades de aprendizagem no meio escolar, confrontando com as experiências de outros países, além de identificar novas perspectivas para a avaliação psicoeducacional no Brasil.

9 Processamento humano de informação e avaliação de leitura e de escrita de crianças
Ângela Maria Vieira Pinheiro
Discute a definição da dificuldade específica da leitura e os requisitos para a avaliação da leitura e da escrita baseada na Teoria de Processamento de Informação, assim como o diagnóstico baseado nesse modelo.
10 Problemas psicossociais e influências na prática da Psicologia Escolar: Investigações sobre o vandalismo no contexto da escola pública
Antônio Roazzi, Claudia Loureiro

\& Circe Maria Gama Monteiro
Apresenta investigações sobre vandalismo no contexto da escola pública, relacionando esse tema à percepção dos alunos sobre a escola onde estudam, à análise da estrutura físicas das instituições escolares e à forma como as pessoas reagem a situações de vandalismo. Destaca a importância da realização de pesquisas acerca dos fenômenos psicossociais para a compreensão dos problemas educacionais.

No primeiro livro da coletânea, Psicologia Escolar: Pesquisa, Formação e Prática, Weschler (1996), ao organizar a referida obra, propôs a articulação dessas temáticas na constituição das práticas 
profissionais em Psicologia Escolar. À época, ao organizar o livro em partes que sintetizassem produções acerca da pesquisa, da formação e da prática, a autora buscou apresentar a ampliação da Psicologia Escolar como área de pesquisa e de produção de conhecimento, além de atuação profissional.

Del Prette e Del Prette (1996), autores de um dos capítulos do referido livro, ao abordarem a prática dos psicólogos escolares, mencionaram as habilidades e conhecimentos necessários à atuação profissional, além de apontarem para as dificuldades encontradas na formação inicial desses psicólogos. Como características profissionais do psicólogo escolar foram apresentadas as capacidades analítica e instrumental: a primeira relacionando-se à avaliação das necessidades e possibilidades de mudança, planejamento de intervenções, identificação dos processos educacionais e sua relação com o contexto sociopolítico; a segunda capacidade, a instrumental, refere-se às habilidades técnicas, tais como observações, realização de entrevistas, aplicação de testes etc., e às habilidades interpessoais, que envolvem a participação no trabalho coletivo, a cooperação, a liderança, a comunicação, dentre outros aspectos relacionais. Esses autores afirmaram que a articulação desenvolvida entre as habilidades analíticas e instrumentais, associadas com as dimensões do conhecimento psicológico e da ética, deve orientar a prática do psicólogo escolar.

Os autores compreendem que a prática do psicólogo escolar deveria ter por objetivo a transformação dos sujeitos, suscitando a elaboração dos conhecimentos que lhe são repassados. Essa ação transformadora teria a função de impulsionar o desenvolvimento das pessoas, inclusive daquele que a realiza. Del Prette e Del Prette (1996) reconheceram que os saberes técnicos sempre foram muito enfatizados na formação acadêmica do psicólogo, entretanto, alegaram ser necessário o "desenvolvimento de habilidades analíticas e interpessoais" (p. 142) e que essas competências deveriam compor o rol de pesquisas e estar presentes no currículo dos psicólogos.

Em outro capítulo do referido livro, Guzzo (1996) discute a formação do psicólogo escolar, fazendo menção às dificuldades encontradas nesse processo. A autora aponta a necessidade do profissional estar comprometido com a realidade em que vive e engajado na construção de uma profissão em sintonia com questões sociais, a fim de transformar as práticas cotidianas da sala de aula. Guzzo (1996) destaca o papel que as associações profissionais, Universidades e Conselhos de Psicologia têm no envolvimento dos psicólogos em projetos e debates éticos, de modo a despertá-los para a função da ciência psicológica frente à sociedade, assim como para a disseminação do conhecimento e das lutas da profissão no país, especialmente aquelas que visem transformações educacionais.

Dentre os empecilhos encontrados na formação do psicólogo escolar no Brasil, que impactam sua identidade e atuação profissional, a autora apresenta três grandes fatores: a) problemas no currículo de formação geral e específica; b) ausência de modelos de atuação profissional específicos do contexto brasileiro; e c) desconhecimento e pouca exigência crítica por parte dos usuários dos serviços prestados pela Psicologia Escolar (Guzzo, 1996, p. 67). Segundo a autora, o currículo de formação inicial deve priorizar a relação entre teoria e prática, garantindo o desenvolvimento profissional mais pleno e 
pautado nas dimensões sociais e práticas, a partir da imersão do psicólogo nos contextos de atuação. A ausência dessa relação deforma a capacitação e o exercício profissional comprometido com a realidade, impactando na forma como o psicólogo escolar chega às instituições educacionais, sem ter experenciado, por vezes, sequer estágios na área de interesse ou de profissionalização.

Guzzo (1996) afirmou que as lacunas na formação repercutem diretamente na prática do psicólogo escolar e apontam para a necessidade de se pensar modelos de atuação profissional discutidos e difundidos para a realidade brasileira, especialmente focados na rede pública de ensino. Nessa dimensão de análise, a autora destaca a necessidade de o psicólogo conhecer e caracterizar as instituições educacionais, identificando suas peculiaridades e necessidades. Como parte desse perfil profissional, ainda, caberia ao psicólogo atuar conjuntamente com os profissionais da Educação e desenvolver uma compreensão social e política do contexto escolar, além de uma ação comprometida, competente e consciente, capaz de transformar a realidade em que está inserido.

No capítulo intitulado Visão transdisciplinar na formação do psicólogo escolar, Novaes (1996) abordou a transdisciplinaridade como condição fundamental para a atuação do psicólogo escolar, ao defender que, aliada aos conhecimentos técnicos e científicos, essa visão favoreceria uma melhor interação do profissional com diversos saberes, em articulação com os conhecimentos da área de educação. Por trabalhar com situações sociais complexas e contextos educacionais singulares, caberia ao psicólogo desenvolver competências de análise, exercitando a "heterogeneidade dos olhares sobre os objetos, sejam fenômenos, processos, situações ou práticas" (p. 115), buscando compreender e explicá-los.

Novaes (1996), ao considerar aspectos do perfil profissional, destacou a importância dos processos criativos serem introduzidos na formação do psicólogo escolar, por promoverem a independência de ação e pensamento, o que colaboraria para um novo entendimento acerca do erro, dos problemas e questões mobilizadoras na atuação, dos imprevistos e da tomada de decisões frente às situações desafiadoras. A autora afirmou, ainda, que o aparecimento e a utilização de novas tecnologias impuseram mudanças no perfil dos profissionais e das instituições, sendo necessário o desenvolvimento da capacidade cognitiva, emocional, linguística e motivacional para lidar com esses recursos inovadores, principalmente nos processos interacionais.

Para finalizar, Novaes (1996) ressaltou o papel da universidade na produção e circulação do conhecimento, preparando psicólogos competentes para o desempenho de seu papel social e profissional. Dentre as funções possíveis de serem desenvolvidas pelo psicólogo escolar, a autora destacou a compreensão da dinâmica escolar e a elucidação do significado psicológico do ato pedagógico, assim como das relações educativas que acontecem em um contexto marcado por sua singularidade e pluralidade.

A seguir, serão apresentadas as informações referentes ao livro Psicologia Escolar: LDB e educação hoje (1999), organizado por Raquel Souza Lobo Guzzo, que se encontra na $4^{a}$ edição. 
Destacar-se-ão alguns capítulos para análise acerca do perfil e das competências profissionais do psicólogo escolar.

Tabela 2

Psicologia Escolar: LDB e educação hoje

\begin{tabular}{|c|c|c|c|}
\hline \multicolumn{2}{|r|}{ CAPÍTULO } & \multirow{2}{*}{ AUTOR(ES) } & \multirow{2}{*}{ SÍNTESE } \\
\hline $\mathbf{N}^{\mathbf{o}}$ & TÍTULO & & \\
\hline 1 & $\begin{array}{l}\text { Psicologia, Educação } \\
\text { e LDB: Novos } \\
\text { desafios para velhas } \\
\text { questões? }\end{array}$ & $\begin{array}{l}\text { Zilda Aparecida } \\
\text { Pereira Del Prette }\end{array}$ & $\begin{array}{l}\text { Enfoca a importância do conhecimento do } \\
\text { conteúdo da LDB por educadores e por } \\
\text { profissionais que atuam na interface da } \\
\text { Psicologia com a Educação. Analisa alguns } \\
\text { artigos da LDB e mostra contradições } \\
\text { relacionadas à atuação do psicólogo em termos } \\
\text { educacionais. }\end{array}$ \\
\hline
\end{tabular}

2 Psicologia escolar e a Ana Maria nova conjuntura Torezan educacional brasileira
Analisa a LDB e o Plano Nacional de Educação, ressaltando a necessidade urgente de transformar o discurso oficial e as práticas sociais previstas na legislação em ações que reflitam uma Educação como direito de todos. Para a Psicologia, o desafio colocado é a revisão da relação com a escola em termos de produção de conhecimento, alijando de seu olhar o processo diagnóstico centrado no aluno e no fracasso escolar.
3 A formação do Psicólogo Escolar e os impasses entre a teoria e a prática
Vera Lúcia

Trindade Gomes
Caracteriza a atuação do psicólogo escolar na área de educação, bem como sua formação acadêmica, o reconhecimento de suas funções e atividades, visando contribuir para a construção do perfil desse profissional. Analisa questões de ordem política, ética e social para a legitimação do psicólogo nos contextos educativos.
4 O psicólogo no cotidiano da escola: Ressignificando a atuação profissional
Sandra Francesca Conte de Almeida

Discute a legitimidade da identidade do psicólogo escolar no cotidiano da instituição educacional, mostrando a necessidade da ressignificação da atuação profissional a partir das especificidades teórico-metodológicas da ciência psicológica. Defende que o psicólogo escolar desenvolva e aperfeiçoe suas competências e responsabilidades técnicas, pessoais e éticas, estabelecendo uma cooperação recíproca entre Psicologia e a Pedagogia.

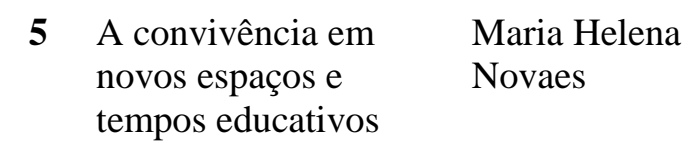

Enfoca o tema inovação trazida pela tecnologia dos meios de comunicação, informação e difusão do conhecimento que apontam para necessidades socioeducativas emergentes. O desafio para o psicólogo escolar deve ser o de ampliar os projetos integrados com as demandas sociais a fim de garantir a continuidade de sua atuação e 
da pesquisa, em todos os níveis de desenvolvimento e escolaridade, a partir de práticas mais inovadoras.

6 Psicólogo Escolar no Geraldina Porto Ensino Superior e a Witter

Lei de Diretrizes e

Bases
Analisa as possibilidades de atuação do psicólogo escolar no seio das Universidades, como profissional e docente, diante do que a LDB define em relação ao Ensino Superior. Discute o tipo de formação que a universidade deve oferecer a este profissional para que ele possa assumir o papel de agente de transformação da realidade educacional brasileira no nível superior.
$7 \quad$ Novo paradigma para a formação e atuação do Psicólogo Escolar no cenário educacional brasileiro
Raquel Souza

Lobo Guzzo
Discute os modelos de atuação do psicólogo no cenário educacional do Brasil, questionando os impasses e dificuldades apresentados nessa realidade. Por outro lado, aponta que investimentos em diferentes áreas de atuação e formação profissional em Psicologia Escolar têm sido feitos com o intuito de buscar um modelo de atuação para este profissional que corresponda às necessidades do sistema educacional brasileiro.

No segundo livro da coleção, intitulado Psicologia Escolar: LDB e Educação Hoje, que teve Guzzo (1999a) como organizadora, as diversas pesquisadoras do GT enfocaram temas que têm direta ou indireta relação com a Lei de Diretrizes e Bases da Educação, implementada em 1996. Diante das lacunas, contradições, omissões e avanços na legislação que regulamenta a educação nas diversas modalidades de ensino, o livro se propôs a discutir as possibilidades de formação e atuação dos psicólogos escolares, bem como as contribuições da Psicologia à Educação com base na nova estrutura e conjuntura educacional formulada.

Torezan (1999) fez uma análise da LDB e do Plano Nacional de Educação - PNE (Brasil, 1998), ressaltando a necessidade urgente de transformar o discurso oficial e as práticas sociais previstas na legislação em ações que reflitam uma Educação como direito de todos. Essa discussão é retratada ao se abordar o tema da inclusão da pessoa com deficiências, que aparecia nas leis e regulamentações da época, mas que era uma questão facultativa. A autora argumentava que o panorama político-social estava em transformação e que a luta pelo direito à educação se fortaleceria com as concepções teóricas que assinalariam novas formas de compreender e analisar a chamada "deficiência", focalizando a atenção para o processo de ensino-aprendizagem do sujeito e não apenas como uma expressão particular de sua individualidade. Para a Psicologia, o desafio colocado foi a revisão da relação com a escola em termos de produção de conhecimento, alijando de seu olhar o processo diagnóstico como centrado no aluno e no fracasso escolar, cabendo ao psicólogo escolar redirecionar seu foco para as múltiplas e complexas questões referentes ao processo de ensino e de aprendizagem. 
Como parte das competências a serem desenvolvidas da formação inicial à atuação profissional, a autora ressalta a capacidade de refletir criticamente sobre as teorias psicológicas utilizadas no cotidiano escolar, principalmente sobre os fundamentos ideológicos que as sustentam. Outro aspecto importante é o conhecimento das legislações educacionais e institucionais e a habilidade em analisar as conjunturas histórica e política do país e os contextos sociais nos quais se faz presente a Psicologia Escolar. Esse conhecimento e capacidade de análise devem conduzir o psicólogo a uma atuação mais crítica, principalmente junto aos professores de cada instituição escolar, para que tomem as próprias ações como objetos de reflexão e ressignificação da prática pedagógica.

Ao analisar a formação do psicólogo escolar, Gomes (1999) evidenciou que esse profissional necessitaria desenvolver uma ação contextualizada e crítica acerca da realidade escolar e de seu papel na sociedade. Para isso, a autora destacou que o psicólogo deveria dialogar com a instituição e com os atores que dela fazem parte, questionando a dinâmica e a ideologia presentes no cotidiano escolar, utilizando os conhecimentos científicos para tais abordagens.

Ao apresentar, no capítulo, o cenário da educação brasileira e os desafios impostos à atuação do psicólogo escolar, Gomes (1999) afirmou que o sistema educacional não viabilizou o desenvolvimento de competências teórico-críticas de seus profissionais, dificultando a compreensão de que teoria e prática deveriam caminhar juntas. Caberia ao psicólogo, dessa forma, intervir nessa realidade e enfrentar as dificuldades, indagando, por meio de sua especificidade profissional, as possibilidades de mudança e desenvolvimento social.

Gomes (1999), ao discutir o perfil do psicólogo que atua no contexto escolar, considerou alguns elementos que influenciam a definição desse perfil, tais como as funções, atividades, saberes teóricos que interferem na atuação; a relação entre a teoria e prática do psicólogo; e, questões de ordem política, social e ética, que legitimam ou não a ação do profissional na educação. A autora afirmou, à época em que elaborou esse estudo, que, apesar de haver produção científica na área de Psicologia, a utilização dos conhecimentos teóricos e técnicos por parte do psicólogo escolar ainda era precário e sugeriu a implementação de políticas e estratégias que melhorassem essa situação.

Ao analisar a formação do psicólogo escolar no futuro, Gomes (1999) indicou a necessidade de reformulação curricular dos cursos de Psicologia, enfocando as demandas éticas e uma maior vinculação dos conhecimentos psicológicos à realidade social brasileira. A autora recomendou, ainda, a construção de um projeto de desenvolvimento que considere as particularidades do povo brasileiro, suas necessidades e possibilidades, a fim de se investir no cidadão, como principal agente de transformação social.

A revisão e a reatualização do campo teórico-conceitual da área foi discutido por Almeida (1999), ao afirmar que a teoria psicológica, a partir de seus argumentos, reflexões e explicações, precisa se traduzir em ações, atitudes e habilidades por parte do psicólogo escolar, com o objetivo de transformar a realidade e as relações sociais vivenciadas na escola. A identidade profissional foi um tema resgatado pela autora, evidenciando a importância do respeito às diferenças e especificidades do 
psicólogo. O desenvolvimento das competências teóricas e metodológicas da Psicologia, aliadas à prática da interdisciplinaridade com os diversos saberes e campos profissionais, permitiria a ampliação das formas de comunicação e de atuação, legitimando e integrando seus saberes e práticas à área educacional. Esse processo de identificação profissional, segundo a autora, exige a ressignificação da atuação e a disseminação dos conhecimentos psicológicos no campo da Educação.

Analisando a prática e a formação profissional do psicólogo escolar, Guzzo (1999b) relata que se buscava um modelo de atuação para o psicólogo escolar que correspondesse às necessidades do sistema educacional brasileiro. Esse modelo deveria ser discutido como política pública desde os anos iniciais, pois a presença e ação dos profissionais no sistema educacional ainda aconteceram, em grande parte, incipientes, indiretas e pouco mobilizadoras. Por ser a escola um espaço de desenvolvimento pessoal e social, a autora defendeu a importância de o psicólogo participar desse contexto, desde que preparado para

entender o sistema educacional em todas as suas dimensões, principalmente a social e política; para estudar o sucesso acadêmico e as formas de implementá-lo nas salas de aula; para desenvolver e avaliar os efeitos de programas de prevenção com o envolvimento de pais e professores, ao invés de atender a casos desviantes em estratégia de atendimento individualizado. (Guzzo, 1999b, p.113)

Guzzo (1999b) ressaltou que essa é uma mudança de paradigma que deveria impactar tanto a legislação educacional brasileira, quanto as diretrizes de formação inicial e continuada dos profissionais da educação, em especial do psicólogo escolar. Desenvolver o olhar para esse amplo contexto, seus atores e formas de intervenção deveria ser competência do psicólogo que atua na escola, que se diferencia e se constitui em suas singularidades, seja pública ou privada, da educação infantil ao ensino superior, enfim, contextos educativos que possuem características distintas dentro de cada realidade. Para a autora, o psicólogo tem um importante papel a ser desenvolvido na escola, por este ser um espaço de desenvolvimento social.

A seguir, serão apresentadas as informações referentes ao livro Psicologia Escolar e Educacional: Saúde e qualidade de vida (2001), organizado por Zilda Aparecida Pereira Del Prette, que se encontra na $4^{\text {a }}$ edição. Destacar-se-ão alguns capítulos para análise acerca do perfil e das competências profissionais do psicólogo escolar.

Tabela 3

Psicologia Escolar e Educacional: Saúde e Qualidade de Vida

\begin{tabular}{|c|c|c|c|}
\hline \multicolumn{2}{|r|}{ CAPÍTULO } & \multirow{2}{*}{$\operatorname{AUTOR}(\mathrm{ES})$} & \multirow{2}{*}{ SÍNTESE } \\
\hline $\mathbf{N}^{\mathbf{o}}$ & TÍTULO & & \\
\hline 1 & $\begin{array}{l}\text { Saúde psicológica, } \\
\text { sucesso escolar e } \\
\text { eficácia da escola: } \\
\text { Desafios do novo }\end{array}$ & $\begin{array}{l}\text { Raquel Souza } \\
\text { Lobo Guzzo }\end{array}$ & $\begin{array}{l}\text { A partir de relatórios e recomendações da } \\
\text { UNESCO, identifica novos desafios para a } \\
\text { escolarização e propõe alterações nos objetivos } \\
\text { e nas práticas dos profissionais da Educação, }\end{array}$ \\
\hline
\end{tabular}


milênio para a

psicologia escolar

particularmente dos psicólogos, destacando a importância da interdisciplinaridade na investigação e nas práticas sobre fatores de proteção e risco no desenvolvimento de crianças em idade escolar, visando à promoção da saúde, cidadania e qualidade de vida.

Sandra Francesca

Conte de Almeida os impasses da educação: Implicações $\mathrm{da}(\mathrm{s})$ teoria(s) na atuação profissional
Examina a atuação, inserção e identidade do psicólogo escolar no campo educacional, discutindo possibilidades e impasses nesse processo, propondo uma articulação entre as teorias psicológicas do desenvolvimento e da aprendizagem e a constituição do sujeito (subjetividade), a partir do aporte teórico da teoria psicanalítica.
3 O psicólogo escolar e a educação: Uma prática em questão
Maria Regina

Maluf

Discute a questão da formação do psicólogo e, em particular, do psicólogo que pesquisa e atua profissionalmente no campo da Educação, à luz dos esforços e reestruturação curricular orientados pela LDB. Destaca a pesquisa em pós-graduação como uma instância que deveria contribuir mais efetivamente para os avanços do conhecimento e da prática em Psicologia Escolar.

4 Modelos interpretativos da criatividade e alternativas de atuação psicossocioeducativa

5 La interrelación entre investigación psicológica y práctica educativa: Un análisis crítico a partir del campo de la creatividad
Maria Helena

Novaes

Analisa os modelos, paradigmas e nova questões de pesquisa no âmbito da educação escolar, relacionado essas questões aos conhecimentos produzidos sobre os temas criatividade e habilidades sociais.

Apresenta uma revisão de pesquisa na área de criatividade e suas aplicações na Educação, analisando criticamente a utilização de resultados de pesquisas no delineamento de estratégias educativas, apontando para limitações que impedem os avanços mais significativos na área.

6 Habilidades sociais e educação: Pesquisa e atuação em psicologia escolar/educacional
Zilda Aparecida Pereira Del Prette \& Almir Del Prette

Discute a função social ampliada da escola com vistas à promoção do desenvolvimento e da qualidade de vida de educadores e educandos. Faz uma síntese de investigações e serviços relacionados ao tema das habilidades sociais, sugerindo direções de pesquisa e atuação que poderiam nortear a prática do psicólogo comprometido com tal tema.

7 Trabalho infantojuvenil: Impacto sobre a educação através de índices de evasão e repetência escolares
Herculano Campos

\& Magda

Dimenstein e

Rosângela

Francischini
Analisa a questão da exploração do trabalho infanto-juvenil no Nordeste (mais especificamente em uma região do Rio Grande do Norte), relacionando esse problema à evasão e à repetência escolar. Reflete sobre as dificuldades da instituição escolar em adequar- 
se às demandas sociais e sobre as articulações entre o sistema sociopolítico e o educacional, que afetam a qualidade de vida e o direito à educação de uma ampla parcela da população brasileira.

\begin{tabular}{|c|c|}
\hline $\begin{array}{l}\text { A escola, a rua e a } \\
\text { criança em }\end{array}$ & $\begin{array}{l}\text { Sílvia Helena } \\
\text { Koller }\end{array}$ \\
\hline
\end{tabular}

Apresenta resultados de vários estudos sobre experiências de crianças em situação de rua, enfatizando aspectos familiares e escolares que deveriam subsidiar programas de prevenção ao fracasso escolar e manutenção da criança na escola. Discute questões da educação relacionadas às populações em risco social, destacando o papel do psicólogo e dos educadores com desenvolvimento humano em contexto formal e informal.

\section{Significações de} professores sobre a escola: O caso de uma escola pública em um assentamento habitacional no Distrito Federal

\section{Tânia Maria de} Freitas Rossi

Apresenta estudo sobre representações com professores de um assentamento habitacional no Distrito Federal, mostrando um contexto limitador para as práticas educacionais e um desafio ao desenvolvimento da escolarização dos alunos. Destaca a necessidade de o psicólogo escolar considerar os fatores escolares e extraescolares para a ampliação do papel educativo em sua prática profissional.
10 Análise de uma experiência de parceria interinstitucional em saúde do adolescente: Possibilidades, limites e implicações para a pesquisa
Ana Cecília de

Sousa Bastos,

Darci Neves

Santos, Mirela

Santos Figueiredo

e Miriã Ramos

Alcântara
Aborda o trabalho realizado pela Fundação Cidade Mãe, em Salvador, e as estratégias desenvolvidas no amparo à infância e à adolescência pelo projeto Educação para a Cidadania, Saúde e Qualidade de Vida. Discute a articulação entre o fazer pedagógico e a promoção de qualidade de vida e desenvolvimento para a comunidade em risco social, bem como o papel da universidade na formação e oferta dos recursos teóricometodológicos para esse fim.

As discussões da Psicologia Escolar relacionadas ao sistema educacional formal e informal, bem como aos desafios que perpassavam e perpassam a escola ainda hoje, foram levantados no livro Psicologia Escolar e Educacional: Saúde e Qualidade de Vida, organizado por Del Prette (2001). Nessa obra, os temas abordados destacaram a concepção da Psicologia Escolar comprometida com a escola e seu papel social, de forma a garantir saúde e qualidade de vida aos sujeitos que compõem essa instituição, apesar dos impasses, contradições e desafios encontrados no cotidiano escolar.

No primeiro capítulo, Guzzo (2001) propôs-se a discutir a situação do ensino fundamental dentro do sistema educacional brasileiro, e as possibilidades interventivas do psicólogo escolar nesse contexto, com ênfase nos processos de sucesso escolar e eficácia na escola. Caberia à Psicologia Escolar, segundo a autora, a criação de uma nova proposta de formação, que habilitasse o profissional 
e entender e trabalhar com as políticas públicas e na conscientização da comunidade escolar acerca das necessidades dos estudantes.

Guzzo (2001) defendeu o princípio de que a escola do futuro deveria privilegiar o tema da multiplicidade, no qual as diferenças e as singularidades seriam respeitadas e conhecidas. No entanto, esse novo desenho da escola brasileira estaria ainda distante de ser implementando, conforme salientou a autora, pois a instituição escolar estaria impregnada pelo autoritarismo, por processos que alimentam violências, sendo um espaço alienante e pouco motivador para os atores educacionais.

Como características do perfil profissional do psicólogo escolar, diante da situação escolar que enfrenta, Guzzo (2001) salientou que caberia a esse profissional o dever de impactar a realidade, entendendo os atores educacionais como sujeitos de sua história. Outro aspecto destacado pela autora seria contribuir para transformar a escola em um espaço democrático de desenvolvimento humano, a partir da humanização das relações sociais e a construção da identidade e participação social dos membros da comunidade escolar. O psicólogo poderia, na atuação profissional, desenvolver ações para a promoção da saúde e bem-estar subjetivo dos sujeitos, minimizando situações de risco social, estabelecendo um trabalho integrado a outros setores que influenciam a vida dos estudantes.

Almeida (2001) destacou, em um dos capítulos do livro, a necessidade de o psicólogo escolar realizar escolhas teóricas e tomar decisões implicadas na relação teoria-prática, ressignificando sua práxis e sua identidade profissional, respaldados por valores éticos e político-sociais. Uma das práticas do psicólogo defendida pela autora foi a da escuta dos discursos dos sujeitos e da instituição, por meio do desenvolvimento de uma sensibilidade para 'olhar' as relações, olhar o outro enquanto sujeito de aprendizagem e sujeito de ensino. Outra ação a ser desenvolvida pelo psicólogo em instituições educacionais é a criação de espaços de discussão, de análise entre os atores, permitindo a circulação de significados e sentidos acerca dos fatos e fenômenos escolares. Em resumo, Almeida (2001) indicou a necessidade de compreender a subjetividade individual e social (institucional), já que essa é uma temática própria do estudo da ciência psicológica e, portanto, relacionada à atuação do psicólogo escolar.

O capítulo apresentado por Maluf (2001), destacou que uma das condições necessárias para o psicólogo escolar é a compreensão da complexidade do fenômeno educacional, sendo necessária uma formação teórica aprofundada em bases filosóficas e epistemológicas que entendam a dinamicidade do campo escolar. Para a autora, a capacidade de entender as relações no contexto educacional e nas situações de aprendizagem, para além do atendimento aos alunos com dificuldade no aprender, caracterizam o perfil profissional a ser desenvolvido pelo psicólogo escolar.

Foi evidenciada, ainda, a questão da nomenclatura que define o campo de atuação do psicólogo em instituições escolares: Psicologia Escolar, Psicologia Educacional, Psicologia na Instituição Escolar ou Psicologia nos Meios Educacionais, este último nome preferido pela autora. Maluf (2001) defendeu a ideia de que, independente do nome utilizado para designar o psicólogo que atua na escola, o perfil do psicólogo escolar deverá estar pautado em uma prática que considere as interações próprias do 
processo educacional e das situações de aprendizagem, envolvendo indivíduos, famílias e a comunidade escolar como um todo. Outro aspecto a ser considerado na atuação do psicólogo escolar, segundo Maluf (2001), são as particularidades dos contextos sociais e culturais em que se desenvolvem as práticas educativas, o que permitiria ao psicólogo a reflexão da prática profissional desde a formação inicial, capacitando-o para o reconhecimento da heterogeneidade presente nesses espaços.

A seguir, serão apresentadas as informações referentes ao livro Psicologia Escolar: Ética e Competências na Formação e Atuação Profissional (2003), organizado por Sandra Francesca Comte de Almeida, que se encontra na $3^{a}$ edição. Destacar-se-ão alguns capítulos para análise acerca do perfil e das competências profissionais do psicólogo escolar.

Tabela 4

Psicologia Escolar: Ética e Competências na Formação e Atuação Profissional

\begin{tabular}{|c|c|c|c|}
\hline \multicolumn{2}{|r|}{ CAPÍTULO } & \multirow{2}{*}{ AUTOR(ES) } & \multirow{2}{*}{ SÍNTESE } \\
\hline $\mathbf{N}^{\mathbf{o}}$ & TÍTULO & & \\
\hline 1 & $\begin{array}{l}\text { Psicologia e } \\
\text { educação: Nossa } \\
\text { história e nossa } \\
\text { realidade }\end{array}$ & $\begin{array}{l}\text { Alacir Villa Valle } \\
\text { Cruces }\end{array}$ & $\begin{array}{l}\text { Destaca o processo histórico da Psicologia no } \\
\text { Brasil, a regulamentação da profissão e dos } \\
\text { cursos em nível superior, informando sobre a } \\
\text { ampliação de números de profissionais após esse } \\
\text { processo. Discute a inserção do psicólogo nos } \\
\text { meios educacionais e reforça a importância de se } \\
\text { pensar a formação do psicólogo articulada às } \\
\text { discussões sobre as diretrizes curriculares. }\end{array}$ \\
\hline
\end{tabular}

2 O psicólogo na escola: Avaliação da formação à luz das demandas do mercado
Herculano R.

Campos \&

Margareth R. B. L. Jucá

Analisa o percurso da Psicologia na área escolar, criticando a aplicação do modelo médico de intervenção no interior das instituições educativas, a partir da patologização desse espaço e do uso de técnicas e instrumentos que alimentam a perspectiva da culpabilização do aluno. Por fim, destaca a necessidade, por parte do psicólogo, do desenvolvimento de uma postura crítica e criativa, a partir de uma base teórica consistente.

3 Psicologia Escolar Institucional: Desenvolvendo competências para uma atuação relacional
Claisy Maria Marinho-Araujo \& Sandra Francesca Conte de Almeida

Apresenta as ações do Projeto Permanente de Extensão Integração Universidade - Psicologia Escolar e discute os caminhos da institucionalização da Psicologia Escolar no Distrito Federal. Debate questões referentes ao desenvolvimento de competências para a construção do perfil profissional do psicólogo escolar da Secretaria de Educação do Distrito Federal (SEDF).

4 A atuação da Psicologia Escolar no atendimento aos alunos encaminhados
Marisa Maria Brito da Justa Neves \& Sandra Francesca Conte de Almeida
Analisa as queixas escolas e problematiza a atuação do psicólogo escolar no questionamento e proposição de alternativas para o atendimento aos alunos com dificuldades de aprendizagem. 
com queixas

escolares
Propõe um modelo de atendimento denominado Procedimentos de Avaliação e Intervenção das Queixas Escolares - PAIQUE, que prevê estratégias de intervenções com o professor, com a família e com o aluno.
5 O psicólogo na construção da proposta pedagógica da escola: Áreas de atuação e desafios para a formação
Albertina Mitjáns Martínez

Apresenta, a partir de estudo de caso, as possibilidades de atuação do psicólogo escolar na construção da proposta pedagógica da escola, destacando os desafios que essa ação representa para a formação profissional e pessoal.

6 Repensando a formação e o Maria Helena exercício profissional Novaes do Psicólogo Escolar na sociedade pósmoderna

7 Psicologia Escolar: Novos olhares e o desafio das práticas
Maria Regina Maluf
A partir do trabalho docente em nível superior, e pela realização de pesquisas e orientação de teses e dissertações, discute o tema da formação e atuação do psicólogo na educação. Defende o reconhecimento da natureza social do comportamento humano, a convivência com a pluralidade metodológica e o reconhecimento das bases culturais da aprendizagem e do desenvolvimento psicológico, como ações afirmativas que sustentam o surgimento de uma nova Psicologia Escolar.
8 Significações sobre a Tânia Maria de atuação do Psicólogo Freitas Rossi \& Escolar

\author{
Divaneide Lira \\ Lima Paixão
}

Apresenta a relação entre identidade profissional e a atuação do psicólogo escolar, tendo por parâmetro a análise das expectativas socais dos professores em relação à prática do psicólogo. Relata que há indícios de uma oposição entre o aspecto funcional $\mathrm{e} o$ aspecto imaginário do papel do psicólogo escolar, tendo em vista as representações dos dois grupos estudados.
9 Educação para a Liberdade, Psicologia da Libertação e Psicologia Escolar: Uma práxis para a liberdade
Raquel Souza Lobo Guzzo

Apresenta uma forma de pensar a formação do psicólogo escolar inserido em um contexto de trabalho, tendo como meta o desenvolvimento saudável de crianças tipicamente brasileiras e sulamericanas. Discute a importância de o psicólogo estar comprometido com a realidade em que vive e questiona a formação oferecida nas universidades, que não o prepara para esse compromisso profissional e social.
10 A ética do sujeito no campo educativo
Sandra Francesca Conte de Almeida
Questiona se tem existido na formação profissional do psicólogo escolar um lugar para a questão da ética do sujeito no campo educativo. 
Discute a ética em uma perspectiva crítica e reflexiva sobre a ação humana, não se reduzindo a um conjunto de normas e prescrições sociais. Aponta temas e metodologias para a compreensão de alguns dispositivos que podem colaborar com a proposta de formação de educadores e psicólogos escolares sustentada em uma ética das práxis educativa, considerando os sujeitos em suas singularidades.

Em mais um livro da coletânea, intitulado Psicologia Escolar: Ética e Competências na Formação Profissional, organizado por Almeida (2003), foram discutidos diversos temas em seus capítulos: a relação entre a Psicologia e Educação no Brasil, a identidade profissional e as competências necessárias para a atuação do psicólogo escolar; os desafios e demandas postos à Educação e ao que fazer do psicólogo escolar; o papel político e ético do psicólogo frente às exigências sociais.

A relação entre a Psicologia e a Educação é apresentada por Cruces (2003), na tentativa de situar historicamente a presença do psicólogo nas instituições escolares, bem como as concepções, metodologias e práticas que caracterizaram a atuação desse profissional nesse contexto. Após algumas considerações sobre a presença deste profissional na escola e diante do panorama educacional e social do país à época, a autora questionou qual deveria ser a formação do psicólogo para o atendimento às demandas apresentadas e, particularmente, como construir profissionais preparados e implicados no trabalho da Educação.

A autora apontava para uma mudança de concepção e atuação do psicólogo escolar a partir da construção de modelos de trabalho que contemplassem toda a instituição e não apenas o aluno, individualmente. Essa mudança requeria do psicólogo uma reflexão sobre sua formação continuada e sobre as demandas do contexto em que estava trabalhando, o que exigia deste profissional pensar criticamente e de forma inovadora as práticas e pesquisas no campo educacional, apesar de existirem ações que sustentavam uma visão individualizada e curativa que, em geral, culpabilizavam o indivíduo pelo problema.

O capítulo escrito por Campos e Jucá (2003) analisou a caminhada histórica da Psicologia no Brasil, das primeiras práticas ao surgimento dos cursos de graduação e o progressivo desenvolvimento da profissão no país. Em relação à formação e atuação do psicólogo escolar, Campos e Jucá (2003) realizaram uma pesquisa com psicólogos que atuavam em escolas públicas e privadas de ensino fundamental e médio, no Rio Grande do Norte, a fim de verificarem a inserção desses profissionais no campo educacional e as características de suas práticas. Os autores verificaram que existia um movimento de busca por novas possibilidades de atuação e de um novo perfil para a caracterização da psicologia na escola.

Dentre os novos indicadores observados pelos autores, estavam a realização de atividades e projetos voltados à equipe escolar e às famílias, fugindo do foco das queixas escolares relacionadas aos 
estudantes. Na ocasião, Campos e Jucá (2003) classificaram essas práticas como inovadoras, por voltarem-se a todos os atores educacionais. Entretanto, os relatos da pesquisa apontavam para diversas formas de atuação profissional que revelavam a tendência tradicional, como o atendimento aos alunos, a orientação vocacional e aconselhamento psicológico.

Ao analisarem os desafios enfrentados pelos cursos de Psicologia, os autores defenderam a ideia de que "o problema do psicólogo escolar não seria resolvido favorecendo uma formação específica da área, mas através da existência de uma formação realmente básica e generalista" (Campos \& Jucá, 2003, p. 53). Nessa visão, a formação inicial deveria fornecer subsídios para que o profissional atuasse nos diferentes contextos, a partir de uma base teórica consistente e uma postura crítica e criativa para a produção de práticas profissionais socialmente relevantes.

Marinho-Araujo e Almeida (2003) apresentaram, em seu capítulo, proposta de atuação relacional, na qual os psicólogos escolares deveriam voltar-se à compreensão dos processos intersubjetivos que caracterizam as relações sociais e, em particular, as relações vivenciadas dentro da escola. As autoras defenderam que o psicólogo poderia criar interlocuções com e entre professores, privilegiando, além dos aspectos e objetivos pedagógicos, o movimento de conscientização de papéis, funções e responsabilidades desses atores educacionais.

Para a realização das ações e intervenções nos contextos educacionais, as autoras propõem uma categorização de saberes e habilidades com base nas competências profissionais a serem desenvolvidas pelo psicólogo escolar:

- Saberes teóricos - fundamentação teórico conceitual e metodológica das diversas áreas da Psicologia e da Educação.

- Saberes técnicos - ações metodológicas, tecnológicas e operacionais, articuladas aos conhecimentos teórico-conceituais.

- Saberes práticos - conhecimentos prévios, intuitivos e advindos da história de vida e da experiência cotidiana, transformados a partir da articulação aos conhecimentos formais.

- Habilidades interpessoais - características de relacionamento social que se desdobram em ações coletivas e na constrição de espaços de interlocução.

- Habilidades pessoais - características e recursos pessoais disponibilizados como metas de desenvolvimento pessoal e profissional.

- Habilidades éticas - capacidade de buscar as várias verdades presentes na intersubjetividade das relações, em ações reflexivas e críticas.

- Habilidades estéticas - capacidade de potencializar a imaginação, a perspicácia, a fantasia e a criatividade como processos psicológicos favoráveis à atuação no contexto escolar.

Os saberes e as habilidades listados reúnem diversos comportamentos, ações, percepções e capacidades distintas por parte do psicólogo em seu campo de atuação, que tanto se desenvolvem nas relações e na sua história de vida, como também podem ser intencionalmente planejadas em proposições 
formativas e no desenvolvimento da prática profissional, nos mais variados contextos. Nessa perspectiva, competência não é sinônimo de habilidade, mas é entendida como a capacidade do sujeito para "agir reflexivamente e eficazmente em um determinado tipo de situação, apoiada em um conjunto articulado e dinâmico de conhecimentos, saberes, habilidades, esquemas mentais, atitudes e posturas" (Marinho-Araujo \& Almeida, 2003, p. 70).

O desenvolvimento de competências para uma atuação institucional, segundo Marinho-Araujo e Almeida (2003), evidencia a especificidade do trabalho realizado pelo psicólogo no contexto escolar, o que requer deste profissional a construção de um perfil que contemple: (a) conscientização de possibilidades e competências em desenvolvimento; (b) capacidade de iniciativa e autonomia; (c) capacidade de análise, aplicação e reelaboração do conhecimento psicológico; (d) clareza quanto aos conhecimentos teóricos da Psicologia e sua aplicação ao campo educacional; e) postura crítica e reflexiva acerca do mundo e das práticas pedagógicas; e (f) comprometimento com o exercício de uma função político-social transformadora. Para o desenvolvimento desse perfil profissional, as autoras destacaram a necessidade de o psicólogo ser e fazer parte da instituição, em seu cotidiano e em suas práticas diárias.

Ao discutir a inter-relação Psicologia-Educação, Mitjáns Martínez (2003) escreveu acerca da participação do psicólogo na elaboração do projeto político-pedagógico da escola, sendo esta uma possibilidade de atuação emergente que favoreceria e evidenciaria a contribuição que o saber psicológico poderia proporcionar ao campo da Educação, além de remeter o psicólogo a desafios profissionais e pessoais diante de um novo campo de ação. A autora, ao falar sobre as competências e características profissionais e pessoais que favoreceriam a atuação do psicólogo no contexto escolar, visando justamente uma maior participação, articulação e legitimação do espaço do psicólogo, destacava a necessidade do desenvolvimento de "habilidades comunicativas, capacidade de trabalhar em equipe, criatividade, comprometimento com os resultados do trabalho e capacidade de autocrítica" (p.122). A autora defendeu que, apesar dessas competências poderem e serem desenvolvidas no contexto de trabalho, deveriam ser contempladas e pensadas desde a formação inicial do psicólogo, antecedendo sua inserção no contexto escolar.

Relacionado ao papel da Psicologia Escolar na construção e implementação da proposta pedagógica na escola, Mitjáns Martínez (2003) apresentou possibilidades de atuação e desafios para a formação profissional do psicólogo: a) o trabalho como consultor ou assessor, requisitado pela gestão escolar; b) a coordenação, elaboração e execução de projetos junto à equipe de trabalho da escola; c) a participação na formação de professores; d) a participação na organização e execução na seleção de professores e coordenadores pedagógicos. Essas sugestões para a atuação do psicólogo não eram inovadoras, mas sugeriam práticas diversificadas para a consolidação da proposta pedagógica da escola, pois se relacionavam aos aspectos humanos, instrumentais/metodológicos ou institucionais, caracterizando o psicólogo como um profissional integrado à escola. 
Em relação ao perfil profissional, Mitjáns Martínez (2003) destacou que algumas características e competências são importantes para o trabalho do psicólogo escolar, entre as quais foram citadas a criatividade, a capacidade de trabalhar em equipe, as habilidades comunicativas, a capacidade de autocrítica e o comprometimento com os resultados do trabalho. A autora defendeu a ideia de que essas competências poderiam ser desenvolvidas diretamente no contexto de trabalho, mas que já existe fundamentação teórica e metodológica para investir-se na formação inicial dos psicólogos que atuarão nas escolas, antecedendo sua inserção no campo profissional.

No quarto capítulo do livro, Neves e Almeida (2003) analisaram as concepções e as práticas dos psicólogos em relação às queixas escolares e apresentaram um modelo de intervenção que colaborasse para a superação de visões reducionistas dentro da escola. Nesse modelo, foram levados em consideração os fatores sociais e culturais que permeiam o processo de ensino e aprendizagem, deixando de atribuir aos estudantes a causalidade do fracasso escolar.

A proposta interventiva, sugerida pelas autoras, foi denominada Procedimentos de Avaliação e Intervenção das Queixas Escolares - PAIQUE, e previa a utilização de estratégias com o professor, com a família e com os estudantes. Segundo as autoras, esse modelo diferenciou-se em sua concepção sobre a queixa, por considerar, além das dimensões social e cultural, os "aspectos subjetivos presentes na demanda, na expressão, no acolhimento e no encaminhamento dessa situação" (Neves \& Almeida, 2003, p. 98). Para o psicólogo escolar, a proposta de intervenção indicava, inicialmente, que o trabalho fosse desenvolvido junto ao professor e à escola, visando à compreensão da histórica escolar do estudante. Caso essas intervenções não se mostrassem suficientes, caberia ao psicólogo realizar outras ações e envolver, assim, a família e o aluno.

Neves e Almeida (2003) destacaram alguns pressupostos que poderiam nortear novas práticas interventivas dos psicólogos relacionadas às queixas escolares, quais sejam: a superação da dicotomia avaliação/intervenção; a compreensão da autonomia e competência profissional do professor; à escuta do docente e dos discursos institucionais, para melhor entender as dificuldades do aluno; a compreensão da história escolar do estudante; o entendimento do papel das famílias e de suas singularidades; e o conhecimento da "versão" do aluno sobre as próprias dificuldades e acerca de sua vida escolar. Esses pressupostos foram formalizados, então, na proposta do Procedimentos de Avaliação e Intervenção das Queixas Escolares (PAIQUE).

O nono capítulo da obra apresentou o trabalho de Guzzo (2003), que analisou a formação do psicólogo escolar inserido em um contexto de trabalho, tendo como meta o desenvolvimento saudável de crianças tipicamente brasileiras e sul-americanas. A autora discutiu a importância de o psicólogo estar comprometido com a realidade em que vivia e questionar a formação oferecida nas Universidades, que não o prepararia para esse compromisso profissional e social.

Guzzo (2003) apoiou suas considerações na perspectiva da Psicologia da Libertação (MartínBaró, 1983, 1986), e afirmou que a ciência psicológica ganha importância e sentido na medida que responde às demandas sociais da comunidade. Como competências profissionais do psicólogo, pautadas 
nesses pressupostos, estão o desenvolvimento do compromisso moral e crítico, um posicionamento político diante das desigualdades sociais e a recuperação da memória histórica da população, visando à conscientização das pessoas.

Ao analisar o currículo para uma ação libertadora, Guzzo (2003) considerou que todos os que dele participam deveriam "aprender a pensar e compreender o mundo pela história", "aprender a explorar o conhecimento exercitando na prática a discussão das contradições", necessitariam "aprender a tomar decisões e a avaliar as consequências" e precisariam "exercer, avaliar e construir políticas públicas e sociais com a psicologia", de forma a responder às demandas da realidade e superar as amarras da alienação, do fatalismo e dos saberes instituídos. Esses seriam os desafios do estudante de psicologia diante da atuação profissional e das possibilidades de transformação social que poderia implementar.

A seguir, serão apresentadas as informações referentes ao livro Psicologia Escolar e Compromisso Social (2005), organizado por Albertina Mitjáns Martínez, que se encontra na $3^{\mathrm{a}}$ edição. Destacar-se-ão alguns capítulos para análise acerca do perfil e das competências profissionais do psicólogo escolar.

Tabela 5

Psicologia Escolar e Compromisso Social

\begin{tabular}{|c|c|c|c|}
\hline \multicolumn{2}{|r|}{ CAPÍTULO } & \multirow{2}{*}{$\operatorname{AUTOR}(\mathbf{S})$} & \multirow{2}{*}{ SÍNTESE } \\
\hline $\mathbf{N}^{\mathbf{0}}$ & TÍTULO & & \\
\hline 1 & $\begin{array}{l}\text { A escola amordaçada } \\
\text { e o compromisso do } \\
\text { psicólogo com este } \\
\text { contexto }\end{array}$ & $\begin{array}{l}\text { Raquel Souza } \\
\text { Lobo Guzzo }\end{array}$ & $\begin{array}{l}\text { Problematiza a escola e o processo educativo } \\
\text { imersos em uma sociedade capitalista, } \\
\text { especialmente pelo olhar da Psicologia. Defende } \\
\text { que a Educação poderia assumir o papel de } \\
\text { promover condições para uma transformação } \\
\text { social, onde a igualdade entre as pessoas e a } \\
\text { convivência respeitosa contribuíssem para a } \\
\text { formação de um coletivo mais justo. Apoiada em } \\
\text { Martin-Baró, aponta que o processo de } \\
\text { conscientização dos indivíduos deve ser uma } \\
\text { meta e uma ação desenvolvida pelo psicólogo } \\
\text { escolar. }\end{array}$ \\
\hline
\end{tabular}

2 Violência na escola: o Psicólogo Escolar na fronteira da política educacional
Herculano Ricardo Campos, Ana Cristina G. Lopes, Marcus Henrique

L. Onofre, Leonardo B. G. Alexandre \& Fábio V. C. Silva
Discute a problemática da violência em articulação com as políticas públicas e busca identificar em que medida a comunidade envolvida em ações educativas de Natal/RN tem se apropriado da evolução do quadro de violência na escola, ampliando a visão sobre esse panorama. Defende que essa temática faz parte do campo de intervenção do psicólogo escolar e de outros profissionais da educação. 
3 Práticas emergentes em Psicologia

Escolar: Nova ética, novos compromissos
Alacir Villa Valle

Cruces

Analisa as práticas desenvolvidas na área escolar por profissionais recém-formados em Psicologia, com o objetivo de identificar novos paradigmas de ciência e novos padrões éticos. Destaca o papel da formação dos psicólogos na construção de profissionais com maior compromisso social, que propiciem e efetivem a inclusão de crianças no processo educacional.

Defende a ideia de que o psicólogo que trabalha com questões relacionadas à escolarização inicial necessita dispor de conhecimentos sobre os processos de aprendizagem e ensino da linguagem escrita. Argumenta que o psicólogo que atua no ensino fundamental deverá ser capaz de favorecer o acesso aos conhecimentos psicológicos para todos os envolvidos no processo educativo.

$\begin{array}{ll}\text { Inclusão Escolar: } & \text { Albertina Mitjáns } \\ \text { desafios para o } & \text { Martínez } \\ \text { psicólogo } & \end{array}$

Apresenta três desafios colocados ao trabalho do psicólogo escolar acerca da inclusão escolar: as mudanças de representações e concepções, o trabalho em relação à subjetividade social da escola e o compromisso social relacionado a essa temática. Reflete sobre possíveis estratégias de atuação perante o novo cenário gerado pelas políticas públicas de inclusão.

6 O psicólogo nas redes de serviços de Educação Especial: Desafios em face da inclusão
Alexandra Ayach Anache

Analisa a participação de psicólogos que atuam em equipes de atendimento a sujeitos que apresentam necessidades educacionais especiais, tanto em instituições governamentais, quanto em não-governamentais do estado de Mato Grosso do Sul. Sugere a ampliação do campo de atuação do psicólogo para além do diagnóstico e encaminhamento, desenvolvendo uma visão crítica sobre as práticas nos espaços educativos.
7 Psicologia Escolar e Educação Inclusiva: Novas práticas de atendimento às queixas escolares
Marisa Maria Brito da Justa Neves \& Ana Cláudia Almeida Machado
Discute as práticas de atuação em Psicologia Escolar que favoreçam a consolidação da escola brasileira como uma escola para todos, expressando o compromisso social do psicólogo com os pressupostos da Educação Inclusiva. Apresenta uma nova forma de atuação dos psicólogos escolares em relação às queixas escolares, propondo um modelo de avaliação e intervenção denominado Procedimentos de Avaliação e Intervenção das Queixas Escolares PAIQUE.

$\begin{array}{lll}8 & \text { Estratégias } & \text { Celia Vectore } \\ \text { mediacionais: } & \\ & \text { Possibilidades de } & \\ & \text { inserção do Psicólogo } & \end{array}$

Apresenta dois programas de intervenção mediacional, o MISC - Mediational Intervention for Sensitizing Caregivers e o APE - Processo de Avaliação e Melhoramento da Qualidade na 
Escolar/Educacional

em abrigos
Aprendizagem Pré-Escolar Efetiva, com o objetivo de traçar um panorama acerca desses programas, discutindo a pertinência da utilização dessas propostas por psicólogos escolares atuantes em instituições que atendem crianças e famílias em situação e risco.
9 Alternativas de atuação da Psicologia Escolar junto à terceira idade
Maria Helena N.

Mira, Rachel M.

M. Tardin \&

Elaine M. Pedroza

Analisa os aspectos biopsicossociais do envelhecimento e as contribuições da gerontologia educacional para a compreensão dos processos, necessidades, conteúdos e contextos de aprendizagem relacionados às pessoas de idades mais avançadas. Propõe a ação do psicólogo escolar no diagnóstico, prevenção, orientação e acompanhamento de idosos e dos programas educativos nos quais estão inseridos.

10 Formação e atuação do Psicólogo Escolar da Rede Pública de Ensino do Distrito Federal: Panorama atual e perspectivas futuras
Sylvia Regina C. Magalhães Senna \& Sandra Francesca C. de Almeida
Retrata o panorama da profissão, considera aspectos positivos e negativos que permeiam o desenvolvimento da Psicologia Escolar e a trajetória de formação do psicólogo escolar no DF, levantando aspectos pessoais, institucionais, sociais e culturais da sua atuação. Demonstra as importantes contribuições deste profissional de Psicologia nas questões relacionadas ao fracasso escolar, às relações interpessoais, aos processos cognitivos, à inclusão escolar, à superdotação, dentre outras temáticas que envolvem a prática do psicólogo na escola.
11 Da Competência teórica à implicação subjetiva: Uma experiência de formação em psicologia escolar/educacional
Cynthia Pereira de Medeiros

Defende a existência de três marcos fundamentais de trabalho em uma perspectiva crítica de formação e atuação em Psicologia Escolar: o papel da escola, as concepções de desenvolvimento, ensino e aprendizagem e uma determinada concepção de subjetividade.
12 Psicologia Escolar: Recriando identidades, desenvolvendo competências

\begin{abstract}
Claisy Maria
Marinho Araujo \&

Sandra Francesca

Ao discutir a dimensão histórica da construção da identidade profissional do psicólogo escolar, destaca a necessidade da criação de espaços formativos que contemplem o desenvolvimento de saberes e competências, em uma formação mais crítica, ética e socialmente comprometida. Destaca a formação continuada em serviço como uma alternativa teórico-metodológica de desenvolvimento profissional.
\end{abstract}

No quinto livro da série, foi proposto um olhar para novas formas de atuação e de compreensão da realidade social, apresentando desafios para a formação do psicólogo escolar, além da discussão sobre as implicações que o compromisso social do psicólogo tem para o ensino na pós-graduação. A partir de debates e levantamento de temas subjacentes a esses, Mitjáns Martínez (2005) organizou o 
livro Psicologia Escolar e Compromisso Social: Novos Discursos, Novas Práticas, enfatizando a interface desse tema com a atuação e a formação do psicólogo escolar.

Nessa obra, Cruces (2005), ao discutir as práticas emergentes em psicologia escolar, reforçou a importância da inclusão escolar para todas as crianças e não apenas para as portadoras de deficiências, em uma nova visão sobre o papel do psicólogo na escola e sobre suas potencialidades de ação. A construção dessa visão, segundo a autora, perpassava pela construção da identidade profissional e da formação coadunada a princípios éticos e de cidadania.

Foram apontados exemplos de atuação profissional mais comprometidos com os grupos e indivíduos, de forma crítica e transformadora, tais como realização de oficinas temáticas com pais e professores, palestras e formação com grupos de professores e observação de alunos em sala de aula. Cruces (2005) afirmou que os psicólogos têm assumido o papel na mediação e transformação das relações interpessoais, visando o desenvolvimento humano dentro da escola. Outras características assinaladas pela autora foram o desenvolvimento de uma postura mais crítica e um compromisso com a construção das práticas educacionais que considerassem as potencialidades dos sujeitos.

A partir de pesquisas, revisões bibliográficas e outros estudos, Marinho-Araujo e Almeida (2005) afirmaram, no referido livro, que um dos maiores problemas da área de Psicologia Escolar era a "falta de clareza e de consistência nas definições acerca da identidade profissional do psicólogo escolar" (p. 243), mas que, por outro lado, essa falta gerava uma busca por conhecimentos e aproximação à especificidade profissional em nível teórico e metodológico, diferenciando e caracterizando esse profissional de tantos outros que estão na escola. Neste trabalho, as autoras defenderam que o grande desafio não era apenas reconhecer a necessidade de revisão da desse processo, mas enfrentar as situações já detectadas e fomentar propostas de formação, atuação e construção da identidade profissional do psicólogo. Para tanto, foram apontadas como necessárias ações de maior engajamento social e uma prática intencional e lúcida, respaldadas pela compreensão da realidade histórico-social dos sujeitos envolvidos.

As autoras defenderam a ideia de que a identidade profissional é construída por características particulares da profissão, que são constituídas por meio de uma história, de traços e conhecimentos que a definem. Segundo Marinho-Araujo e Almeida (2005), a identidade

não existe como espaço independente dos campos de ação e prática social do sujeito, nem se delimita como categoria isolada nas configurações de sentidos subjetivos individuais; ela deve ser compreendida como um dos sistemas simbólicos do sujeito, cujos diferentes sentidos subjetivos não se constituem alheios ao contexto no qual o sujeito se desenvolve; a identidade não tem uma delimitação inflexível, enquanto configuração subjetiva, mas se organiza e funciona a partir de formas diferenciadas e históricas de produção de sentidos. (Marinho-Araujo \& Almeida, 2005, p. 248)

A partir do entendimento do conceito de identidade profissional, o capítulo sinalizou a urgente necessidade de criação de espaços formativos para o psicólogo, que evidenciassem possibilidades de 
ressignificação dos saberes e competências profissionais. Esses espaços deveriam ser renovados constantemente, pois o processo de construção da identidade profissional é dinâmico e histórico, sendo necessária a oxigenação de novas habilidades, saberes e reflexões por parte do psicólogo.

Seguindo a linha editorial do livro em questão, o tema do compromisso social também foi discutido por Guzzo (2005), centralizando no processo de conscientização um dos principais papéis do psicólogo escolar. Conscientização é entendida, pela autora, como um processo de mudança pessoal e social daquele que está alienado ou oprimido, impactando em como o sujeito se relaciona com o mundo, de forma mais crítica sobre si mesmo e sobre a sua realidade. Nessa perspectiva, caberia ao psicólogo desenvolver uma postura crítica frente às desigualdades e injustiças sociais, ao fracasso escolar, à produção dos diversos tipos de violências no cotidiano da escola, à culpabilização de famílias, professores e alunos pelas dificuldades existentes nas relações educativas, enfim, uma postura de conscientização de si mesmo e dos outros.

Uma competência e um compromisso político e ético do psicólogo escolar é o desenvolvimento do bem-estar de todos os envolvidos nos processos educativos e na comunidade escolar da qual esse profissional faz parte. Na visão da autora, a escola é, antes de tudo, um espaço comunitário, sendo necessário o trabalho em redes de apoio que garanta maior justiça social aos seus participantes. Ao psicólogo caberia, segundo a autora, o papel de intervir nos processos subjetivos que, de alguma forma, sustentam a injustiça social e a tornam possível. Para isso, esse profissional necessitaria repensar a própria função, assumindo a perspectiva do interesse coletivo, em detrimento da acomodação e da conformação diante dos problemas sociais (Guzzo, 2005, p. 28).

O capítulo de Anache (2005) analisou a participação de psicólogos que atuavam em equipes de atendimento a sujeitos que apresentavam necessidades educacionais especiais, tanto em instituições governamentais, quanto em não governamentais do estado de Mato Grosso do Sul. Foi discutida a validade do conhecimento da Psicologia em relação à área do ensino especial, em uma tentativa de compreender os processos de inclusão e exclusão do estudante com necessidades educacionais especiais.

Anache (2005) observou que as intervenções do psicólogo escolar, referentes ao trabalho desenvolvido na educação especial, caracterizavam-se por: avaliação e diagnóstico; encaminhamento dos alunos; orientação a professores, famílias e alunos; e acompanhamento para o mercado de trabalho. A autora, ao citar esses procedimentos, em análise às propostas de desenvolvimento de todos os estudantes, considerou que haviam contradições a esse respeito, pois as práticas continuavam a referendar laudos e psicodiagnósticos que focalizavam as dificuldades e desvios do aluno.

A autora realizou uma análise de conjuntura e problematizou a questão da inclusão, tão difundida nos discursos acerca do aluno com direito à educação especial, ao indagar que tipo de inclusão estava sendo praticada nos contextos educacionais e, com base nisso, que objetivos deveriam ser alcançados. Anache (2005) afirmou que a educação inclusiva de qualidade deveria permitir, 
indiscriminadamente, que os estudantes tivessem acesso à escola, além de terem condições adequadas para o desenvolvimento do processo de ensino e aprendizagem.

A seguir, serão apresentadas as informações referentes ao livro Formação em Psicologia Escolar: Realidades e Perspectivas (2007), organizado por Herculano Ricardo Campos, que se encontra na $1^{a}$ edição. Destacar-se-ão alguns capítulos para análise acerca do perfil e das competências profissionais do psicólogo escolar.

Tabela 6

Formação em Psicologia Escolar: Realidades e Perspectivas

\begin{tabular}{|c|c|c|c|}
\hline \multicolumn{2}{|r|}{ CAPÍTULO } & \multirow{2}{*}{$\operatorname{AUTOR}(\mathrm{ES})$} & \multirow{2}{*}{ SÍNTESE } \\
\hline $\mathbf{N}^{\mathbf{o}}$ & TÍTULO & & \\
\hline 1 & $\begin{array}{l}\text { A Psicologia Escolar } \\
\text { nas diretrizes } \\
\text { curriculares: Espaços } \\
\text { criados, desafios } \\
\text { instalados }\end{array}$ & $\begin{array}{l}\text { Claisy Maria } \\
\text { Marinho-Araujo }\end{array}$ & $\begin{array}{l}\text { Discute os desafios apresentados ao cenário da } \\
\text { graduação em Psicologia a partir da promulgação } \\
\text { das Diretrizes Curriculares Nacionais, enfocando } \\
\text { a especificidade da formação em Psicologia } \\
\text { Escolar. }\end{array}$ \\
\hline
\end{tabular}

2 Formação inicial em psicologia escolar: Questões apontadas por alunos de graduação
Marisa Maria Brito da Justa Neves

Discute questões da área de Psicologia Escolar apresentadas por alunos de graduação do curso de Psicologia da Universidade de Brasília. A partir dessas questões foi realizada uma reflexão sobre o quanto o ensino de graduação está traduzindo a produção teórica da área e a visão acerca do campo educativo.

3 Psicologia escolar: Perspectivas e compromissos na formação continuada
Claisy Maria Marinho-Araujo \& Marisa Maria Brito da Justa Neves
Apresenta ações de formação continuada para psicólogos escolares no DF, que têm por objetivos o reconhecimento de sua identidade profissional e das competências necessárias ao exercício dessa identidade. São delineadas as atividades de Extensão Universitária e de Especialização Lato Sensu do Laboratório de Psicogênese do Instituto de Psicologia da UnB.
4 A educação e a educação do psicólogo: Ideias e práticas de pesquisaação-formação
Sônia Maria Rocha Discute a pesquisa-ação-formação de psicólogos Sampaio e outros agentes educativos a partir do Projeto Mestre Pastinha: Uma Escola Integrando Educação Ambiental e Prevenção do Uso de Drogas e DST/AIDS. Na perspectiva de uma pesquisa etnográfica, propõe a utilização dos diários de campos como base para a produção teórica e analítica das práticas desenvolvidas no projeto.
5 O Psicólogo Escolar e os processos de implantação de políticas públicas: Atuação e formação
Albertina Mitjáns Martínez

Analisa o papel do psicólogo escolar no processo de implementação de políticas educacionais que implicam em algum tipo de inovação na instituição escolar. Discute a produção científica da área e a implantação de políticas públicas relacionadas à inclusão escolar. Defende o 
processo de autonomia do psicólogo, enquanto sujeito reflexivo, no desenvolvimento e responsabilização por sua formação profissional.

6 A formação do Psicólogo Escolar e a atuação em instituições infantis:

Da história às práticas atuais
Celia Vectore \&

Eulália $\mathrm{H}$.

Maimoni

Apresenta vários direcionamentos pelos quais atravessou a Psicologia Escolar, indicando as especificidades de contextos e a dinamicidade dos processos em cada lugar. Apresenta uma proposta de atuação de estágio e supervisão na Psicologia Escolar em contextos de educação infantil.

7 Reflexões a respeito da atuação do psicólogo no campo da psicologia escolar/educacional em uma perspectiva crítica

Marilene Proença Rebello de Souza

Propõe a identificação de trabalhos de pesquisa que sustentem a afirmação de que existe, no campo da Psicologia Escolar e Educacional do Brasil, um movimento de superação de modelos psicológicos tradicionais, para uma mudança que busque formas de aproximação com a instituição educacional, dentro de uma perspectiva crítica.

8 Psicólogos recémformados: Oportunidades de trabalho e atuação na área educacional
Alacir Villa Valle Cruces \& Maria Regina Maluf
Apresenta estudos que visavam contribuir para a caracterização da profissão por meio da investigação das preferências de um grupo de psicólogos recém-formados, mostrando as oportunidade de atuação que tiveram após a conclusão do curso de graduação. Discute, ainda, concepções sobre o fracasso escolar e laudos psicológicos de crianças com problemas de aprendizagem.
9 A pessoa com deficiência mental entre os muros da educação
Alexandra Ayach Anache
A partir de trabalhos de pesquisa realizadas junto às redes de serviço de Educação, busca identificar as concepções de aprendizagem e de desenvolvimento construídas tendo por base os relatórios de estudantes avaliados pelos serviços de educação especial, do qual o psicólogo participa.
10 Como estranhos no ninho: O diferente jeito de viver das pessoas com a Síndrome de Asperger
Eliana Rodrigues Araújo \& Herculano R. Campos

Apresenta uma pesquisa sobre como jovens acometidos da Síndrome de Asperger compreendem e percebem a própria doença, seus comportamentos e características. A partir de como procedem as demandas específicas desses sujeitos, propõe o desenvolvimento de programas de tratamento e acompanhamento das pessoas com a referida Síndrome.

O tema da formação em Psicologia Escolar sempre permeou, ao longo dos anos, diversas discussões, produções científicas e debates no meio acadêmico. No GT de Psicologia Escolar da ANPEPP esse assunto também foi contemplado na publicação do livro Formação em Psicologia Escolar: Realidades e Perspectivas, organizado por Campos (2007), que apresenta reflexões sobre: a 
articulação entre formação e atuação, as práticas inclusivas garantidas nas políticas públicas, a atuação profissional dos psicólogos recém-formados, o impacto da pesquisa científica na formação do profissional. Todos esses assuntos são tranversalizados pelo tema da formação inicial, tendo por objetivo, como destaca o organizador, refletir acerca da contribuição do psicólogo escolar para a construção de uma sociedade mais justa.

O capítulo inicial do livro discutiu a Psicologia Escolar nas Diretrizes Curriculares Nacionais para os Cursos de Psicologia, aprovadas em fevereiro de 2004, contribuindo para a apresentação de articulações entre as propostas formativas contempladas nas Diretrizes e as demandas de transformação da formação do psicólogo escolar. Em um dos principais tópicos discutidos no capítulo, que trata da questão do perfil profissional, Marinho-Araujo (2007) apontou que "o ponto de partida para se planejar a implantação das Diretrizes Curriculares deva ser o perfil profissional esperado ao egresso da graduação em Psicologia.” (p.19). Entende-se que a compreensão do perfil profissional deva contemplar um aperfeiçoamento constante e o desenvolvimento de competências diversas, tais como criatividade, tomada de decisão, iniciativa e aperfeiçoamento constante. Em relação às Diretrizes Curriculares, a autora destacou a importância da ampliação teórica do conceito de competências, visando à clarificação do perfil profissional a ser formado, contemplando o desenvolvimento da criticidade e do comprometimento com a transformação das condições sociais em que se situa o psicólogo escolar.

Em relação ao perfil profissional, Marinho-Araujo (2007) acredita que a formação em Psicologia Escolar deveria pautar-se na transformação das concepções cristalizadas acerca do processo de desenvolvimento e aprendizagem humano, com a mudança do foco do fracasso para o sucesso escolar e a construção de estratégias que visassem a promoção do bem-estar dos sujeitos. Para que essas concepções sejam efetivamente transformadas, a autora sugeriu a instalação de fóruns de discussão, de espaços de reflexões coletivas e trocas de experiências que permitiriam o desenvolvimento dos fundamentos das competências profissionais necessárias ao exercício do psicólogo escolar, considerando as Diretrizes Curriculares, mas, também, levando em conta outros fatores que contribuem para a formação do profissional, sejam políticos, econômicos e legais.

No capítulo apresentado por Marinho-Araujo e Neves (2007), foram discutidas ações de formação continuada de psicólogos escolares desenvolvidas pelas autoras, que enfocaram o tema da identidade profissional e as competências necessárias para o seu exercício. Essa formação, cujo desenho foi delineado no capítulo em questão, foi dirigida aos psicólogos que atuavam na rede pública de ensino do Distrito Federal.

As autoras defenderam a ideia de que a especificidade da atuação do psicólogo escolar exige a consolidação de um perfil profissional que considere competências diversas, dentre as quais, citadas por Marinho-Araujo e Neves (2007): iniciativa e autonomia frente a situações de conflitos ou decisões; capacidade de análise, reelaboração e aplicação do conhecimento psicológico; profunda clareza da relação entre concepções teóricas da Psicologia e a atuação profissional; postura crítica e reflexiva acerca das práticas sociais; intencionalidade nas ações comunicativas que legitimem a intervenção 
profissional; e o exercício de sua função político-social e ética. Essas competências atualizam-se nas práticas profissionais exercidas pelo psicólogo, que se encontra imerso no contexto escolar, mas, também, pelas discussões teórico-conceituais relacionadas à formação e atuação em Psicologia Escolar.

Marinho-Araujo e Neves (2007) enfatizaram o papel da Universidade não apenas com a formação inicial dos psicólogos, mas com contínuas intervenções na realidade profissional que objetivassem o atendimento às demandas sociais. Para as autoras, a maior demanda na formação continuada é a de uma eficaz articulação entre teoria e prática, pesquisa e desenvolvimento de competências na formação. O Projeto Permanente de Extensão Integração Universidade/Psicologia Escolar, que à época da publicação do livro funcionava há 11 anos, foi considerado um exemplo dessa possibilidade de ação junto aos psicólogos e a seus contextos de atuação, aproximando o conhecimento produzido na Universidade a práticas reais desenvolvidas nos contextos educacionais.

Por fim, Marinho-Araujo e Neves (2007) afirmaram que a formação continuada em serviço deveria "ser incorporada às funções formativas das instituições de ensino superior" (p. 85), e que contemplasse o desenvolvimento de competências na práxis. Assim, os psicólogos escolares poderiam perceber alternativas ao seu desenvolvimento profissional, desde que pautadas em "pesquisas, construções teóricas, práticas reflexivas, sugeridas sob a ética do compromisso" (p. 85).

O capítulo proposto por Mitjáns Martínez (2007) analisou o papel do psicólogo escolar no processo de implementação de políticas educacionais que implicavam em algum tipo de inovação na instituição escolar. A autora destacou o acompanhamento de uma proposta de política relacionadas com a inclusão escolar e assinalou os desafios colocados ao psicólogo escolar para o desenvolvimento de sua formação profissional e inserção nessa temática.

Ao questionar qual a formação necessária para que o psicólogo compreendesse a complexidade dos processos gerados pela necessidade de implantar as políticas públicas, Mitjáns Martínez (2007) propôs três teses que poderiam ser o suporte à sua preparação para assumir novas funções. A autora afirmou que o psicólogo necessita "ter como foco sua formação como sujeito" (p. 121), devendo ser considerada sua condição individual e os processos subjetivos que o caracteriza. A segunda tese considerou que a formação inicial deveria estar direcionada ao "desenvolvimento de representações abrangentes da complexidade do funcionamento psicológico humano" (p. 125), o que implicaria, para o psicólogo, a necessidade de compreender a complexidade dos sujeitos e de seu funcionamento nos diversos espaços em que atua. Como terceiro ponto, a "formação continuada é uma responsabilidade do próprio psicólogo" (p. 128), que deve ser assumida como um processo permanente de aprimoramento da prática profissional e de aceitação de novos desafios.

Mitjáns Martínez (2007) destacou que a capacidade autodidata seria essencial na prática do psicólogo escolar, além de outras competências profissionais importantes para a implementação de políticas públicas: o conhecimento acerca da legislação, o aprofundamento acerca dos processos de mudanças institucionais e o entendimento sobre as especificidades das barreiras que se contrapõem às 
inovações pedagógicas. Essas competências, apesar de serem discutidas como temas da formação do psicólogo, evidenciam-se nos contextos concretos e complexos, também formativos para o profissional.

A seguir, serão apresentadas as informações referentes ao livro Psicologia Escolar: Novos Cenários e Contextos de Pesquisa, Formação e Prática (2009), organizado por Claisy Maria MarinhoAraujo, que se encontra na $2^{\text {a }}$ edição. Destacar-se-ão alguns capítulos para análise acerca do perfil e das competências profissionais do psicólogo escolar.

Tabela 7

Psicologia Escolar: Novos Cenários e Contextos de Pesquisa, Formação e Prática

\begin{tabular}{|c|c|c|c|}
\hline \multicolumn{2}{|r|}{ CAPÍTULO } & \multirow{2}{*}{$\operatorname{AUTOR}(\mathbf{E S})$} & \multirow{2}{*}{ SÍNTESE } \\
\hline $\mathbf{N}^{\mathbf{o}}$ & TÍTULO & & \\
\hline 1 & $\begin{array}{l}\text { Desafios e } \\
\text { perspectivas para a } \\
\text { Psicologia Escolar } \\
\text { com a implantação } \\
\text { das Diretrizes } \\
\text { Curriculares }\end{array}$ & $\begin{array}{l}\text { Alacir Villa Valle } \\
\text { Cruces }\end{array}$ & $\begin{array}{l}\text { Analisa as propostas de formação de cursos de } \\
\text { graduação de Psicologia após a implementação das } \\
\text { Diretrizes Curriculares Nacionais, principalmente } \\
\text { quando se referem à preparação de psicólogos para } \\
\text { atuação no campo educacional. São verificadas as } \\
\text { ênfases escolhidas, as disciplinas que prepararão } \\
\text { os profissionais para essa atuação, os estágios e } \\
\text { atividades práticas a ela relacionadas. }\end{array}$ \\
\hline
\end{tabular}

2 Formando Psicólogos Raquel Souza Escolares: Problemas, Lobo Guzzo, vulnerabilidades, desafios e horizontes
Adinete Sousa da

Costa \& Izabella

Mendes Sant'Ana

Apresenta resultados preliminares de um estudo realizado entre 2003 e 2008 acerca da vivência no estágio de Psicologia Escolar no atual contexto de formação do psicólogo, avaliando o impacto dessa experiência curricular na delimitação dos problemas. Busca identificar as dificuldades na formação e suas repercussões para a vida dos estagiários.

3 A Atuação dos Psicólogos Escolares no Distrito Federal
Marisa Maria Brito da Justa Neves

Analisa e caracteriza a atuação de psicólogos escolares do Distrito Federal, a fim de conhecer as práticas desenvolvidas por esses profissionais no atendimento às demandas a eles dirigidas.

4 A Atuação do Psicólogo na rede pública de educação frente à demanda escolar: Concepções, práticas e inovações
Marilene Proença Rebello de Souza \& Silvia Maria Cintra da Silva
Realiza um mapeamento da atuação profissional do psicólogo escolar em estados brasileiros que possuem Instituições de Ensino Superior de formação em Psicologia, nas Regiões Norte, Sul, Nordeste e Sudeste. Analisa concepções e práticas desenvolvidas pelos psicólogos na rede pública diante das queixas escolares.
5 A intervenção do psicólogo na formação de professores: Contribuições da
Marilda Gonçalves Dias Facci

Analisa algumas contribuições da Psicologia Histórico-cultural para a atuação do psicólogo escolar junto a professores, destacando a necessidade do processo de humanização dos alunos e professores. 
Psicologia Histórico-

cultural

6 Educação, valores e Vera Lucia

formação de

Trevisan de Souza

Identifica alguns elementos que demandam professores:

atenção do psicólogo escolar em sua prática ou campos de pesquisa, quais sejam a educação e seu

Contribuições da papel na formação dos alunos, do professor e de si

Psicologia Escolar mesmo, colaborando para a constituição dos sujeitos em espaços educativos.

7 Psicologia Escolar na Claisy Maria Educação Superior: Marinho-Araujo Novos cenários de intervenção e pesquisa
Apresenta reflexões acerca de inovadoras perspectivas de trabalho para a Psicologia Escolar, defendendo a expansão dos objetos de ação e pesquisa para o contexto da Educação Superior.
8 Explorando possibilidades: $\mathrm{O}$ trabalho do psicólogo na educação superior
Sônia Maria Rocha A partir de duas narrativas recolhidas entre Sampaio estudantes ingressos por reserva de vagas na Universidade Federal da Bahia, busca compreender a natureza e qualidade das diferentes experiências relatadas. As narrativas contribuem para o entendimento de como as políticas públicas privilegiam o ingresso, a convivência e a permanência com sucesso dos estudantes.
9 O Psicólogo Escolar e o processo de escolarização de pessoas com deficiência intelectual
Alexandra Ayach Anache

Com base nas discussões realizadas por pesquisadores brasileiros e pelos achados da pesquisa em questão, bem como as ações de extensão e ensino relacionadas ao processo de escolarização de alunos que apresentam deficiência mental, discute o lugar do psicólogo escolar no contexto da educação especial.
10 A contribuição do Psicólogo Escolar para 0 desenvolvimento das altas habilidades
Denise de Souza Fleith

Discute as contribuições da Psicologia Escolar para o desenvolvimento das altas habilidades. Apresenta concepções e características relacionadas ao fenômeno das altas habilidades, analisando o papel do psicólogo escolar no desenvolvimento da superdotação nos contextos escolar e familiar. Aponta tendências atuais e os desafios da atuação desse profissional no desenvolvimento de sujeitos com altas habilidades no contexto da inclusão escolar.

Analisa a situação de abrigamento e defende que o

11 Abrigamento,

Celia Vectore \& narrativas infantis: A Cíntia Carvalho importância da Psicologia Escolar em contextos de abrigo

12 Consumo de álcool pelas adolescentes:
Herculano R. Campos \& Débora contar histórias pode ser um importante instrumento do psicólogo na atuação junto às crianças, assim como na formação dos educadores e mães sociais provenientes de abrigos 


$\begin{array}{ll}\text { Um (novo) desafio } & \text { Karla Sampaio } \\ \text { para o psicólogo na } & \text { Alves } \\ \text { escola } & \end{array}$

sentidos atribuídos a esse comportamento, bem como os motivos que levam as adolescentes a consumirem abusivamente o álcool. Questiona qual o papel do psicólogo ante essa nova demanda

Os desafios colocados com a implantação das Diretrizes Curriculares voltam ao debate com a publicação do livro Psicologia Escolar: Novos cenários e contextos de pesquisa, formação e prática, organizado por Marinho-Araujo (2009a). Além desse tema, a produção dos autores voltou-se também às concepções e fundamentos que embasam as práticas dos psicólogos escolares e às possibilidades de ampliação de pesquisa e de intervenção no campo da Psicologia Escolar.

Neves (2009) abordou a atuação do psicólogo escolar na rede pública de ensino, focalizando seu estudo no Distrito Federal, objetivando apresentar a forma como os psicólogos atendiam as demandas institucionais a eles dirigidas, apontando para variadas possibilidades de atuação no contexto educacional, além de destacar a necessidade da formação continuada e do estabelecimento de parcerias entre os diversos atores da escola. A autora relatou que a atuação do psicólogo não poderia estar dissociada do cotidiano escolar, cabendo a esse profissional desenvolver, junto aos professores, estratégias pedagógicas que favorecessem a aprendizagem de todos os estudantes.

Ao discutir a pesquisa realizada com psicólogos escolares, a autora enumera pontos de reflexão sobre as percepções desses profissionais acerca de suas próprias práticas, especialmente dificuldades na formação inicial e a necessidade de reconhecimento da profissão. Aparece nos relatos pouca articulação com os professores, o que remete a uma urgência no desenvolvimento de novas formas de ação junto aos outros profissionais da escola.

É apontada por Neves (2009), a necessidade de se conhecer a escola, sua complexidade e dinamismo, as práticas e concepções dos outros profissionais que constituem essa instituição social. A construção do trabalho coletivo deve ser uma meta do psicólogo, tanto para a reflexão dos atores educacionais, quanto para a consolidação de práticas inclusivas, permitindo o convívio com as diferenças, desconstruindo uma visão idealizada da escola e desses atores.

O capítulo de Marinho-Araujo (2009b) teve por objetivo apresentar reflexões acerca das novas perspectivas de trabalho para a Psicologia Escolar, defendendo a expansão dos objetos de ação e pesquisa para o contexto da Educação Superior. As possibilidades de atuação do psicólogo nesse nível de ensino relacionam-se, conforme apontado pela autora, às mediações na trajetória de desenvolvimento humano adulto, que são oportunizadas pelos processos de ensino e aprendizagem, bem como à intervenção psicológica junto à gestão da instituição, à implementação das diretrizes curriculares, formação continuada de docentes e técnicos, além da realização de ações e assessorias diversas.

Diante da análise produzida por Marinho-Araujo (2009b) acerca da Educação Superior, sua história, a legislação brasileira, os achados internacionais e o crescimento da oferta de vagas nas Universidades, a autora destacou a importância da presença do psicólogo escolar nesse contexto, como mediador do processo de mudança, contemplando ações de cidadania, competência e ética. Essa 
transformação passa, necessariamente, pela alteração do foco de atuação da prática psicológica, indo do individual para o coletivo, considerando as especificidades institucionais, mas se opondo "à lógica de padronização, homogeneização, normatização presente nas formas cada vez mais sutis de controle social" (p. 176).

Caracterizando a atuação do psicólogo escolar na Educação Superior, Marinho-Araujo (2009b) assinalou que poderiam ser desenvolvidas intervenções que oportunizassem processos de conscientização acerca das práticas acadêmicas, favorecendo mudanças na subjetividade dos atores da universidade. Outra característica do perfil profissional do psicólogo seria o compromisso com a própria formação, de forma constante e sistemática. Por último, foi sinalizada a necessidade de repensar a formação inicial e continuada do psicólogo, agregando informações e possiblidades de conhecimento relacionadas à atuação no ensino superior, ampliando intervenções e pesquisas nessa área.

O trabalho de Anache (2009), discutiu o lugar do psicólogo escolar no contexto da educação especial e analisou produções de pesquisadores brasileiros e ações de ensino relacionadas ao processo de escolarização de alunos que apresentavam deficiência mental. A autora considerou que o psicólogo escolar poderia promover processos reflexivos e colaborar na capacitação dos professores, assim como de outros profissionais, favorecendo a construção do pensamento crítico no interior da escola. Complementando as ações que caberiam ao psicólogo, Anache (2009) citou o estímulo às ações colaborativas nos espaços educacionais, pois favoreceria a promoção da investigação dos processos de escolarização dos estudantes com deficiência.

Um dos compromissos do psicólogo escolar, apontado pela autora, é o da transformação do insucesso escolar que os alunos vivenciam em sua história de escolarização, mostrando aos professores, familiares e ao próprio aluno que ele seria capaz de aprender, "desde que as atividades fossem situadas e significadas" (p. 238). Outro desafio foi o de problematizar as crenças e valores acerca do fracasso escolar, sendo necessárias, conforme explicita Anache (2009), de ferramentas teóricas e metodológicas que sustentassem a compreensão do processo de aprendizagem desses estudantes, por vezes limitados pela classificação de um diagnóstico.

Anache (2009), ao finalizar o capítulo, afirmou que a intervenção do psicólogo na escola poderia favorecer a construção de "espaços de interlocução entre outras vozes e dimensões do conhecimento" (p. 240), para que pudessem ser discutidos, aprendidos e conhecidos os discursos que gravitam em torno da aprendizagem do estudante com deficiência intelectual. O lugar do psicólogo, frente a esse campo de atuação, é o da reflexão acerca das práticas, a fim de que não se proceda a uma normalização da condição humana.

Em se tratando das diferenças vivenciadas na escola, o livro apresentou, a partir das elucidações de Fleith (2009), um estudo sobre as contribuições do psicólogo escolar para o desenvolvimento das altas habilidades e do potencial humano em geral. Inicialmente, a autora definiu o conceito de altas habilidades/superdotação, identificando as concepções e abordagens teóricas sobre o assunto e elencou diversas ações que poderiam ser desenvolvidas pelo psicólogo escolar nos contextos escolar e familiar 
relacionados a esse tema. Dentre essas ações discutidas pela autora, foram citadas a análise da dinâmica familiar, observação das interações desenvolvidas na escola, consideração das características subjetivas de cada sujeito, análise de valores e crenças socialmente compartilhados, bem como, por parte do psicólogo, a atualização de conhecimentos sobre a produção da área de Psicologia Escolar.

Dentro das competências profissionais do psicólogo escolar que trabalha com as altas habilidades no contexto escolar, a autora propõe ações/intervenções para essa atuação. Resumem-se, aqui, algumas dessas competências: (a) capacidade de desmistificar ideias enganosas sobre a superdotação, indicando características mais comumente encontradas; (b) pesquisar e disponibilizar informações sobre altas habilidades para a comunidade escolar; (c) orientar professores e demais profissionais acerca das características e atendimentos aos superdotados; (d) colaborar no processo de avaliação e identificação do aluno com altas habilidades, na perspectiva de uma avaliação que ultrapasse o uso de testes psicológicos; (e) participar na elaboração do projeto político pedagógico e sinalizar a necessidade de ações que contemplem aos alunos superdotados; e (f) capacidade de discutir e implementar, no contexto escolar, políticas públicas relacionadas ao alunos com altas habilidades.

Um desafio apresentado ao psicólogo que trabalha com a superdotação foi a questão da formação. Após adentrar ao campo de trabalho e inserido na temática das altas habilidades, como o psicólogo escolar poderia desenvolver os conhecimentos, práticas e reflexões em um processo formativo? É papel da universidade, da rede pública de ensino ou de outras instituições promoverem essa formação? Que modelo proposto poderia contemplar a teoria e a prática do psicólogo para a atuação na superdotação? A autora acredita que esse é um dos grandes desafios para a Psicologia Escolar em relação à compreensão do fenômeno das altas habilidades. Retomando às competências profissionais, Fleith (2009) sinalizou que o psicólogo deveria ser inovador, flexível e reflexivo em sua prática, compreendendo e interpretando o cotidiano escolar em atenção às demandas dessa área de atuação.

A seguir, serão apresentadas as informações referentes ao livro Psicologia Escolar: Identificando e Superando Barreiras, organizado por Raquel Souza Lobo Guzzo e Claisy Maria Marinho-Araujo, que se encontra na $1^{\text {a }}$ edição. Destacar-se-ão alguns capítulos para análise acerca do perfil e das competências profissionais do psicólogo escolar.

Tabela 8

Psicologia Escolar: Identificando e Superando Barreiras

\begin{tabular}{|c|c|c|c|}
\hline \multicolumn{2}{|r|}{ CAPÍTULO } & \multirow{2}{*}{ AUTOR(ES) } & \multirow{2}{*}{ SÍNTESE } \\
\hline $\mathbf{N}^{\mathbf{o}}$ & TÍTULO & & \\
\hline 1 & $\begin{array}{l}2008 \text { - Ano da } \\
\text { Educação para os } \\
\text { Psicólogos: } \\
\text { Encaminhamentos e } \\
\text { próximos passos }\end{array}$ & $\begin{array}{l}\text { Raquel Souza } \\
\text { Lobo Guzzo \& } \\
\text { Adinete Sousa da } \\
\text { Costa Mezzalira }\end{array}$ & $\begin{array}{l}\text { Apresenta os temas debatidos no ano da } \\
\text { Educação e revela a importância das discussões } \\
\text { sobre a aplicação da Psicologia ao campo } \\
\text { educacional, possibilitando a reflexão sobre o } \\
\text { desenvolvimento de esforços para legitimar o } \\
\text { lugar do psicólogo nesse espaço, garantindo sua } \\
\text { atuação profissional na rede pública. }\end{array}$ \\
\hline
\end{tabular}


2 A Política Nacional de Educação Especial na perspectiva da educação inclusiva: Desafios para o Psicólogo Escolar
Denise de Souza Fleith

Discute o papel e os desafios enfrentados pelo psicólogo escolar na implementação da Política Nacional de Educação especial na Perspectiva da Educação Inclusiva, além de propor alternativas de atuação desse profissional em favor da educação que supere a lógica da inclusão e da homogeneidade.
3 Psicologia Escolar no Distrito Federal: História e compromisso com políticas públicas
Claisy Maria

Marinho-Araujo, Marisa Maria Brito da Justa Neves, Paula Cristina Bastos PennaMoreira \& Rejane Maria Barbosa
Reflete sobre o percurso da Psicologia Escolar no Distrito Federal, evidenciando os espaços e avanços conquistados e defendendo uma intensa articulação entre as dimensões teóricas, práticas e políticas de atuação dos psicólogos escolares.
Marilda Gonçalves

Dias Facci \&

Marilene Proença

Rebello de Souza
Apresenta alguns pressupostos da Psicologia Histórico-Cultural, destacando o método instrumental de Vygotsky, com o objetivo de contribuir para o processo de avaliação psicológica das queixas escolares.

Vigotski para o processo de avaliação psicológica

5 Recursos mediacionais:

Possibilidades de uso em contextos infantis

Celia Vectore

Apresenta relatos de estudos que tiveram por objetivo resgatar a importância da ludicidade, agregando atividades como jogos e narrativas, por meio da construção de recursos mediacionais lúdicos, possibilitando intervenções junto às crianças e colaborando para a formação de mediadores.

Defende a adoção de uma concepção para análise

Izabella Mendes Sant'Ana \& Maria Teresa Antunes Albergaria da realidade educacional e superação de visões descontextualizadas e preconceituosas acerca do estudante e suas dificuldades escolares. Discute outras formas de atuação do psicólogo escolar pautadas em bases mais condizentes com a realidade brasileira, especialmente quando relacionadas ao fracasso escolar e às políticas educacionais de aceleração da aprendizagem.

7 A Teoria Históricocultural e o atendimento educacional especializado à pessoa com deficiência intelectual: contribuições à Psicologia Escolar
Sonia Mari Shima Barroco

Discute os aspectos legais que têm norteado o Atendimento Educacional Especializado no Brasil, apresentando elaborações teóricometodológicas de Vygotsky acerca das concepções de aprendizagem e desenvolvimento humano para a superação de intervenções meramente técnicas. Por fim, discute as contribuições e as implicações dessas elaborações para a formação e atuação dos psicólogos e demais profissionais da educação. 
8 Queixas escolares: Conceituação, discussão e modelo de atuação
Marisa Maria Brito Apresenta uma contextualização do conceito de da Justa Neves queixas escolares a partir da discussão e utilização de uma modelo de atuação para o psicólogo escolar.
9 Psicologia Escolar na Educação Superior: Construindo possibilidades diferenciadas de atuação
Claisy Maria Marinho-Araujo \& Cynthia Bisinoto
Analisa a Psicologia Escolar na Educação Superior com foco no desenvolvimento dos sujeitos e na ampliação da perspectiva de atuação, por meio de práticas diferenciadas, privilegiando a formação de indivíduos críticos, éticos, socialmente participativos e compromissados.
10 A Educação Superior como espaço privilegiado para a orientação acadêmica
Sônia Maria Rocha Sampaio

Discute o papel do psicólogo na orientação acadêmica e defende que este profissional dissemine a sistematização, a análise, a circulação e o debate dos resultados dessa atividade no meio acadêmico.
11 Violação dos direitos das crianças na Educação Infantil
Mara A. L. Weber \& Raquel Souza Lobo Guzzo
Discute a atuação do psicólogo escolar em uma instituição pública de educação infantil diante dos valores de liberdade, respeito e dignidade, garantidos pelo Estatuto da Criança e do Adolescente. Analisa o envolvimento desse profissional com as políticas públicas relacionadas aos atores educacionais.
12 Os desafios no cotidiano da escola: Violência, clima social escolar e bullying
Carolina Lisboa, Débora Martins de Campos \& Tatiane de Oliveira Dias
Debate o tema da violência no contexto escolar como sendo de relevância social, que urge ser combatida, minimizada e prevenida. Diferencia os conceitos de agressividade discutindo as consequências para a compreensão dessas expressões na escola e na sociedade. Por fim, destaca o papel do psicólogo no desenvolvimento de espaços de diálogo nesse contexto, em articulação com outros profissionais
13 A arte como mediação nas pesquisas e intervenção em Psicologia Escolar
Vera Lucia

Trevisan de Souza, Ana Paula Petroni \& Lílian Aparecida Dugnani
Reflete sobre o trabalho do psicólogo escolar a partir de um projeto de pesquisa-intervenção realizado pelo grupo de pesquisa Processos de construção do sujeito em práticas educativas, da PUC-Campinas. Visa ao desenvolvimento de projetos de estágio em psicologia escolar de alunos de graduação.
14 Escola e adolescência Ana Vládia em conflito com a lei: Uma estratégia de inclusão perversa

\section{Holanda Cruz \& Herculano R. Campos}

Aborda a atualização de práticas e concepções de cunho menorista, no contexto das escolas frequentadas por adolescentes cumprindo medida de liberdade assistida. Ao se pensar nos adolescentes em conflito com a lei, busca-se formas de inclusão desses sujeitos no sistema educacional 
O nono livro publicado pelo GT de Psicologia Escolar e Educacional da ANPEPP foi intitulado Psicologia Escolar: Identificando e Superando Barreiras. As organizadoras Guzzo e Marinho-Araujo (2011) reúnem diversos textos que problematizam a identificação e o enfrentamento dos limites e desafios relacionados à construção política e profissional da Psicologia Escolar no país, a partir de uma visão crítica da área, compromissada com a promoção do desenvolvimento humano e com a construção de políticas públicas voltadas à Educação, em todos os níveis e modalidades de ensino. As autoras destacaram que a presença formal do psicólogo escolar no sistema escolar brasileiro ainda era uma conquista a ser buscada por esses profissionais e pelos pesquisadores da área.

A Política Nacional de Educação Especial na perspectiva da inclusão é discutida por Fleith (2011) em seu capítulo, quando afirma que essa política é provocadora, instigadora, pois redimensiona a educação especial e propõe à escola a revisão das concepções, práticas e de sua própria organização. Entretanto, a autora sinaliza que as resistências a essas mudanças permanecem no interior das escolas brasileiras, retratando certa acomodação e repetição de práticas educativas excludentes, a despeito da emergência de mudanças dos cenários estabelecidos. Segundo Fleith (2011), características como solidariedade, compreensão e justiça social devem pautar a ação dos psicólogos escolares frente aos desafios da diversidade e da inclusão escolar, ainda que dificuldades, conflitos e incertezas se coloquem diante desse processo de transformação social dos indivíduos e das instituições.

A autora sinalizou que, para o psicólogo, algumas questões estão postas diante da implementação dessa política, entre as quais: a capacidade de refletir o tema da diversidade, reorganizando a forma de pensar e atuar nas escolas; a análise do contexto escolar, de forma a minimizar as barreiras culturais, sociais e pedagógicas, favorecendo o processo de inclusão escolar; o desenvolvimento de novas competências e conhecimentos; a melhor articulação teórico-prática, situando a prática psicológica no momento histórico e legal; e o rompimento de preconceitos e estereótipos, do próprio profissional e dos atores educacionais como um todo (Fleith, 2011, p. 42). Não são poucos os desafios para o psicólogo escolar, mas é premente a necessidade dessa reflexão e mudança de concepção para a inclusão de todos, indistintamente.

No campo das políticas públicas, especificamente no Distrito Federal, Marinho-Araujo, Neves, Penna-Moreira e Barbosa (2011) abordam o percurso, os avanços e os desdobramentos da Psicologia Escolar na rede pública de ensino, destacando a necessidade de o psicólogo escolar constituir-se como membro efetivo do contexto escolar, atuando para a compreensão dos processos de ensinoaprendizagem. No texto é retratada a parceria entre o Instituto de Psicologia da Universidade de Brasília $(\mathrm{UnB})$ e a Secretaria de Educação do DF (SEDF), por meio do Projeto Permanente de Extensão Integrado Universidade/Psicologia Escolar. Esse projeto, iniciado em 1995 e em andamento visa, principalmente, à dinamização e ampliação das relações técnico-científicas entre as instituições, ofertando formação continuada aos profissionais da SEDF, além de contextos reais e fecundos para o estágio dos estudantes do curso de graduação em Psicologia da UnB. Ações como essa, dentre outras, possibilitaram maior visibilidade ao percurso da Psicologia Escolar no DF, sendo permeada por uma 
análise crítica tanto da atuação dos profissionais envolvidos, quanto da valorização das articulações e construções políticas estabelecidas nesse processo histórico.

Uma discussão retratada no capítulo é a importância do envolvimento nas instâncias burocráticas e legislativas para a implementação das propostas de formação e organização do trabalho do psicólogo escolar e, no caso em questão, das Equipes Especializadas de Apoio à Aprendizagem nas quais trabalham os psicólogos escolares na SEDF. Marinho-Araujo, Neves, Penna-Moreira e Barbosa (2011) destacaram a ideia de que, aliadas à capacidades teóricas e práticas, são necessárias ações políticas que viabilizem a atuação e a formação dos psicólogos escolares, sendo esse mais um contexto de inserção do psicólogo na rede pública de ensino.

A respeito da atuação crítica dos psicólogos frente às queixas e demandas escolares, Neves (2011) discute o Procedimentos de Avaliação e Intervenção dos Alunos Encaminhados com Queixas Escolares - PAIQUE. Essa proposta de atuação, discutida pela autora em outros trabalhos (Neves, 2001; Neves \& Almeida, 2003; Neves \& Machado, 2005; Neves \& Marinho-Araujo, 2006) prevê, fundamentalmente, o desenvolvimento da escuta psicológica dos diversos atores e contextos dentro da escola, como uma competência específica do psicólogo escolar, além de contemplar a participação efetiva dos professores no processo de compreensão da queixa formulada e das possibilidades interventivas que privilegiem o desenvolvimento escolar dos alunos. Assim, o psicólogo atua no assessoramento ao professor que encaminha ou promove a queixa, discutindo as concepções de aprendizagem, as potencialidades de desenvolvimento dos alunos e propõe um olhar sobre o sucesso escolar, de forma a maximizar as ações exitosas dentro da escola.

A autora destaca que no PAIQUE são previstos três níveis de avaliação/intervenção que envolvem a escola, a família e o aluno, mas reforça o nível da escola como sendo privilegiado para a aprendizagem e desenvolvimento humano e para a realização de um trabalho de natureza institucional e preventiva. O modelo enfoca, em seus níveis de intervenção, o trabalho realizado pelo psicólogo escolar com o professor, que é considerado um dos principais atores do processo educativo, a partir da reflexão dos encaminhamentos realizados e da ressignificação da queixa por ele apresentada, a partir da discussão dos elementos que compõem a sua prática pedagógica.

A seguir, serão apresentadas as informações referentes ao livro Psicologia Escolar: Desafios e Bastidores na Educação Pública (2014), organizado por Raquel Souza Lobo Guzzo, que se encontra na $1^{a}$ edição. Destacar-se-ão alguns capítulos para análise acerca do perfil e das competências profissionais do psicólogo escolar. 
Tabela 9

Psicologia Escolar: Desafios e Bastidores na Educação Pública

\begin{tabular}{|c|c|c|c|}
\hline \multicolumn{2}{|r|}{ CAPÍTULO } & \multirow{2}{*}{ AUTOR(S) } & \multirow{2}{*}{ SÍNTESE } \\
\hline $\mathbf{N}^{\mathbf{o}}$ & TÍTULO & & \\
\hline 1 & $\begin{array}{l}\text { A Psicologia que } \\
\text { defendemos na escola } \\
\text { que vivemos: Uma } \\
\text { contribuição dos } \\
\text { bastidores do 'Voo da } \\
\text { Águia' }\end{array}$ & $\begin{array}{l}\text { Ana Paula Gomes } \\
\text { Moreira \& Raquel } \\
\text { Souza Lobo Guzzo }\end{array}$ & $\begin{array}{l}\text { Apresenta uma história vivenciada dentro de uma } \\
\text { escola municipal de ensino fundamental, } \\
\text { retratando os descompassos entre o que a escola } \\
\text { compreende sobre a vida de uma criança e a } \\
\text { relação com o seu aprendizado e } \\
\text { desenvolvimento. }\end{array}$ \\
\hline
\end{tabular}

2 O Psicólogo na escola e com a escola: A parceria como forma de atuação promotora de mudanças
Vera Lucia

Trevisan de Souza, Ana Paula Petroni, Lilian Aparecida

Cruz Dugnani, Eveline Tonelotto

Barbosa \& Paula Costa de Andrada

Mostra o trabalho do psicólogo escolar junto a alunos e gestores de uma escola pública, a partir do uso da arte como recurso de acesso à reflexão sobre a realidade escolar. Faz considerações acerca dos limites e desafios da atuação do psicólogo em pesquisas e intervenções na escola.

Fabiola de Sousa Braz Aquino \& Jéssica Andrade de Albuquerque
Evidencia concepções de crianças acerca de suas vivências escolares, apreendendo o que pensam e sentem em relação à escola que frequentam, aos professores, ao modo como os conteúdos são transmitidos e o que gostariam de realizar. Sugere o desenvolvimento de estratégias pedagógicas que favoreçam uma maior participação e engajamento das crianças no seu processo de aprendizagem.

4 O Psicólogo escolar e o projeto políticopedagógico da escola: Diálogos e possibilidades de atuação

5 No cotidiano da escola: A adolescência desperdiçada?
Izabella Mendes Sant'Ana \& Raquel Souza Lobo Guzzo
Apresenta possibilidades de atuação do psicólogo escolar na construção e efetivação do projeto político pedagógico de uma escola pública, a partir da análise de um caso.
Marilda Gonçalves Identifica percepções de adolescentes e Dias Facci professores sobre o estudo da adolescência, discorrendo acerca do desenvolvimento do psiquismo humano e sobre essa fase da vida humana. Defende que os jovens podem apresentar características positivas que necessitam ser mais bem aproveitadas na escola.
6 As contradições dos bastidores da Educação de Jovens e Adultos: Elementos de histórias de vida e expectativas de mudanças
Adinete Sousa da Costa Mezzalira, Maria Áurea Pereira Silva \& Raquel Souza Lobo Guzzo
Destaca o papel político do psicólogo na manutenção, no enfrentamento e na ruptura da organização social e econômica que influencia as condições de vida cotidiana, pois é um profissional que trabalha com a subjetividade humana. Discute a práxis do psicólogo escolar na Educação de Jovens e Adultos, desvelando a 
história de vida dos estudantes que frequentam esse segmento educacional.

7 Intervenção

institucional:

Ampliação crítica e

política da atuação

em Psicologia

Escolar
Claisy Maria

Marinho-Araujo

Apresenta a atuação institucional do psicólogo escolar como alternativa para uma intervenção mais ampla na escola, que pode proporcionar o desenvolvimento de competências profissionais. Como proposta de intervenção, aborda as dimensões de atuação do psicólogo no campo educacional: mapeamento institucional, escuta psicológica, assessoria ao trabalho coletivo e acompanhamento ao processo de ensino e aprendizagem.

8 Da formação à profissionalização de psicólogos no campo educacional: Contribuições de uma epistemologia interacionista

9 Estagiários de Psicologia na escola: $\mathrm{O}$ que os bastidores revelam para a formação profissional?
Virginia Teles

Carneiro \& Sonia

Maria Rocha

Sampaio

Relata a pesquisa acerca da cultura estudantil que envolve a formação do psicólogo, desde sua entrada na universidade até o início da atividade profissional, objetivando entender como estudantes de psicologia tornaram-se psicólogos profissionais, especificamente no campo educacional.

Walter Mariano de Propõe uma reflexão sobre a relação entre a Faria Silva Neto, formação e a atuação do psicólogo escolar a partir Raquel Souza Lobo Guzzo \& Ana Paula Gomes Moreira de uma experiência de estágio curricular conduzida dentro das ações do programa 'Voo da Águia', da PUC-Campinas, no contexto da educação infantil.

10 Psicologia Escolar na Claisy Maria Educação Superior: Desafios e potencialidades

Marinho-Araujo

Discute o papel da Psicologia Escolar na Educação Superior a partir de três eixos principais: expansão e democratização da educação superior; impacto no perfil dos estudantes que chegam a essa modalidade de ensino; atuação emergente da Psicologia Escolar, com possibilidade de mediação no desenvolvimento dos atores educacionais, de intervenção institucional coletiva e ampliada e de pesquisa voltada as transformações sociais emancipadores.

Enfatiza as práticas sociais em torno da cibercultura e a inserção do psicólogo escolar nesse espaço emergente e atual, ao mesmo tempo, como mediador e promotor de desenvolvimento humano e de aprendizagem. Apresenta os desafios ao profissional de Psicologia e as possibilidades de diálogo com o campo da Educação.

12 Clima escolar e violência: Propostas de avaliação e de

Bruna Holst \& Carolina Saraiva de Macedo Lisboa
Investiga, por meio do clima escolar, dos processos de violência e bullying na instituição escolar. Apresenta propostas de avaliação e intervenção 


\begin{tabular}{|c|c|c|c|}
\hline & & & $\begin{array}{l}\text { intervenção em clima escolar, visando a } \\
\text { diminuição da violência. }\end{array}$ \\
\hline 13 & $\begin{array}{l}\text { Serviços de } \\
\text { Psicologia Escolar na } \\
\text { Educação Superior: } \\
\text { Uma proposta de } \\
\text { atuação }\end{array}$ & $\begin{array}{l}\text { Cynthia Bisinoto } \\
\text { \& Claisy Maria } \\
\text { Marinho-Araujo }\end{array}$ & $\begin{array}{l}\text { Analisa algumas possibilidades de atuação dos } \\
\text { profissionais de Psicologia Escolar na Educação } \\
\text { Superior, tanto em relação ao apoio à promoção } \\
\text { das trajetórias de aprendizagem e } \\
\text { desenvolvimento dos estudantes quanto à } \\
\text { assessoria psicológica aos processos de ensino- } \\
\text { aprendizagem e de gestão institucional. }\end{array}$ \\
\hline 14 & $\begin{array}{l}\text { Oportunizando } \\
\text { Atendimento } \\
\text { Educacional a Alunos } \\
\text { Superdotados na } \\
\text { Educação Básica: A } \\
\text { importância da } \\
\text { atuação do psicólogo } \\
\text { escolar }\end{array}$ & $\begin{array}{l}\text { Fernanda do } \\
\text { Carmo Gonçalves } \\
\text { \& Denise de Souza } \\
\text { Fleith }\end{array}$ & $\begin{array}{l}\text { Apresenta argumentos de que o psicólogo escolar } \\
\text { deve ser um agente transformador e de inclusão } \\
\text { de alunos superdotados e um facilitador na } \\
\text { construção de práticas pedagógicas e serviços } \\
\text { psicológicos que respeitem as necessidades dos } \\
\text { estudantes com altas habilidades na educação } \\
\text { básica. }\end{array}$ \\
\hline 15 & $\begin{array}{l}\text { ¿Competencias } \\
\text { Digitales para la } \\
\text { Competitividad? } \\
\text { Reflexiones a partir } \\
\text { de la experiencia de } \\
\text { trabajo con una } \\
\text { escuela de género }\end{array}$ & $\begin{array}{l}\text { Gloria Patricia } \\
\text { Marciales Vivas }\end{array}$ & $\begin{array}{l}\text { Relata uma experiência de trabalho acerca da } \\
\text { escola de gênero da Associação Herrera de } \\
\text { Madrid, da Colômbia, refletindo sobre o papel da } \\
\text { Psicologia Escolar em um contexto complexo. O } \\
\text { projeto intitula-se 'Construções narrativas de } \\
\text { mulheres e a apropriação criativa das } \\
\text { Tecnologias da Informação e Comunicação } \\
\text { (TICs). }\end{array}$ \\
\hline
\end{tabular}

Em 2014, o GT de Psicologia Escolar da ANPEPP lançou o seu mais recente livro, intitulado Psicologia Escolar: Desafios e Bastidores na Educação Pública, organizado por Guzzo (2014) e contando com a colaboração de vinte e três pesquisadores da área. Nesse trabalho, os autores problematizaram as questões legais relacionadas à presença do psicólogo na escola, seja em âmbito nacional, regional ou municipal, além de pensarem sobre a leitura crítica da realidade onde se insere o profissional. Discutiram, ainda, acerca da necessária atualização e desenvolvimento de competências teóricas, metodológicas e práticas para lidar com as demandas encontradas nos contextos escolares.

Souza, Petroni, Dugnani, Barbosa e Andrada (2014) analisaram, como uma das grandes demandas e desafios do psicólogo escolar, o trabalho com parcerias no interior da escola, caracterizando esse profissional como alguém que faz parte da equipe escolar. Foi discutida a atuação institucional do psicólogo, que privilegia os espaços coletivos, avaliando as questões que lhe são apresentadas e buscando agir, nesses espaços, como membro efetivo da escola. Segundo as autoras, o psicólogo escolar poderia desenvolver um posicionamento mais crítico, uma ação política mais engajada e comprometida com a instituição e uma intervenção mais empenhada nos objetivos institucionais, promovendo o desenvolvimento de crianças, jovens e adultos, estudantes ou profissionais que compõem a escola. 
As autoras destacaram que o trabalho de superação dos desafios enfrentados na escola é difícil e exige do psicólogo escolar capacidade para lidar com as frustrações e o medo de não atingir os objetivos propostos. Souza, Petroni, Dugnani, Barbosa e Andrada (2014) defendem a ideia de que, pelo trabalho em parceria e com a divisão de responsabilidades, é possível atender as demandas institucionais e focalizar a atenção no objetivo primordial da escola: o desenvolvimento e aprendizagem dos alunos.

O psicólogo escolar e o projeto político-pedagógico da escola foram os temas abordados por Sant'Ana e Guzzo (2014), que discutiram os diálogos e possibilidades de atuação desse profissional na construção do PPP. O estudo foi realizado em uma escola pública municipal de ensino fundamental do interior paulista e fazia parte do projeto chamado Voo da Águia (Guzzo, 2000).

As autoras assinalaram que o psicólogo escolar deveria participar das discussões do projeto político-pedagógico, próximos aos educadores, conhecendo a dinâmica escolar a fim de favorecer discussões e reflexões acerca das práticas e dos conflitos identificados no cotidiano da escola. Esses momentos, conforme apontaram Sant'Ana e Guzzo (2014), permitiriam a troca de experiências entre os atores educacionais e interlocuções onde os professores dialogariam acerca de suas percepções e intervenções pedagógicas.

As ações desenvolvidas pelos psicólogos do projeto Voo da Águia (Guzzo, 2000), que sinalizaram para o desenvolvimento do perfil profissional, abrangeram os seguintes aspectos: planejamento e discussão com a equipe escolar; conhecimento e implementação de intervenções específicas da atuação psicológica; participação no acompanhamento e avaliação do projeto políticopedagógico; e participação na formação dos professores. Sant'Ana e Guzzo (2014), ao analisarem o papel do psicólogo, afirmaram que caberiam a esse profissional a atuação contextualizada e a utilização dos conhecimentos psicológicos para o fortalecimento e conscientização dos sujeitos.

Em um dos capítulos do referido livro, Marinho-Araujo (2014), analisando a atuação institucional do psicólogo escolar, considerou que o contexto escolar é um espaço complexo e multideterminado, propício às aprendizagens e desenvolvimentos, em função das contradições, antagonismos, inquietações, mas também possibilidades de transformação social e das relações estabelecidas no cotidiano escolar. A autora defendeu a ideia de que as tensões existentes na escola não impossibilitam o surgimento de forças de luta e resistência pela garantia da cidadania. A Psicologia defendida pela autora se compromete com a

construção de concepções críticas e dialéticas sobre o homem, seu desenvolvimento, sua subjetividade, seus processos de aprendizagem e de comunicação; que, a partir dessas concepções, empenhe-se em intervenções que leve em conta as influências histórico-culturais na constituição do psiquismo humano e que sejam respaldadas por opções teóricas que consideram a interdependência entre aprendizagem, desenvolvimento, mediação, consciência e emoção (p.160).

Marinho-Araujo (2014) defendeu que o processo de conscientização proporciona transformações no contexto escolar e nas relações ali estabelecidas, sendo necessária uma forma de 
atuar no coletivo que supere as visões adaptacionistas ou psicologizantes da práxis do psicólogo escolar, favorecendo uma reflexão sobre as práticas pedagógicas. A par disso, a intervenção institucional tornase uma opção teórica e conceitual, crítica e política da atuação do psicólogo, compreendida, dentre outras ações possíveis, no mapeamento institucional, em uma escuta psicológica específica do psicólogo escolar, na assessoria ao trabalho coletivo e no acompanhamento ao processo de ensino e aprendizagem. Essa forma de atuação, apesar de separada em dimensões, representa um processo com características dinâmicas, sistemáticas e participativas, que se inter-relacionam na prática do psicólogo escolar.

A autora afirmou que uma ação institucional deve considerar todos os atores educacionais, os espaços/tempos de interlocução na escola, os procedimentos e documentos legais e institucionais que regulam as práticas profissionais, assim como as questões políticas que perpassam o cotidiano das unidades escolares. Cabe ao psicólogo, segundo Marinho-Araujo (2014), mergulhar e conhecer os processos constitutivos desse contexto, compreender as relações de poder e como elas se organizam, considerar as representações e expectativas relacionadas à sua prática profissional e estudar profundamente a relação entre a Psicologia e Educação.

A produção do GT de Psicologia Escolar/Educacional da ANPEPP é vasta e tem colaborado para a disseminação dos conhecimentos acerca da Psicologia Escolar enquanto campo de produção teórica, de atuação e de pesquisa no Brasil. Os livros e os capítulos retratados exemplificaram um processo de mudança de concepções e práticas do psicólogo escolar que, analisadas historicamente, atualmente voltam-se para uma perspectiva institucional e coletiva, o que tem demandado desse profissional o desenvolvimento de características pessoais e competências profissionais que atendam a essas demandas.

Dentre as novas exigências ao psicólogo escolar, destaca-se a necessidade desse profissional pensar criticamente e de forma inovadora acerca das práticas e pesquisas no campo educacional, desenvolvendo postura ético-política e compromisso social com a escola e os sujeitos envolvidos nesse contexto. Considera-se, ainda, a importância de o psicólogo desenvolver competências relacionais para entender e lidar com os outros atores educacionais com os quais compartilha as atividades profissionais cotidianas.

As produções do GT têm sinalizado para a necessidade de pensar criticamente a atuação do psicólogo escolar e refletir sobre o perfil profissional esperado para ele, da formação inicial à sua inserção no campo de trabalho. Essas produções teóricas permitem, assim, conhecer os papéis e competências profissionais a serem desenvolvidos pelo psicólogo escolar, relacionando-as às suas práticas e contextos, de forma a refletir sobre as concepções e metodologias de trabalho desenvolvidas por estes profissionais no campo da Educação.

\section{A Psicologia Escolar e o Papel do Psicólogo: Contribuições Nacionais e Internacionais}

Os pesquisadores do GT de Psicologia Escolar e Educacional da ANPEPP, além da participação e publicação nos livros apresentados, também mantêm produções acadêmicas em periódicos nacionais 
e internacionais diversos, alimentando a Psicologia Escolar de pesquisas e contribuições teóricas para a área. No ano de 2010, o Instituto Nacional de Estudos e Pesquisas Educacionais Anísio Teixeira ${ }^{2}$ (INEP/MEC), por meio de seu periódico Em Aberto, publicou um número temático intitulado Psicologia Escolar: Pesquisa e Intervenção, organizado por Marinho-Araujo (2010). Os autores que participaram dessa publicação também faziam parte do Grupo de Trabalho de Psicologia Escolar e Educacional da ANPEPP e os artigos apresentados colaboraram para evidenciar novas demandas de conhecimento em Psicologia Escolar, refletir e reafirmar o compromisso social na formação de profissionais da área, sejam pesquisadores, professores ou psicólogos escolares atuantes nos mais diversos contextos, inclusive aqueles relacionados às políticas públicas e outras ações multidisciplinares.

Tabela 10

Psicologia Escolar: Pesquisa e Intervenção

\begin{tabular}{|c|c|c|c|}
\hline \multicolumn{2}{|r|}{ CAPÍTULO } & \multirow{2}{*}{ AUTOR(ES) } & \multirow{2}{*}{ SÍNTESE } \\
\hline $\mathbf{N}^{\mathbf{0}}$ & TÍTULO & & \\
\hline 1 & $\begin{array}{l}\text { Psicologia Escolar: } \\
\text { Pesquisa e } \\
\text { intervenção }\end{array}$ & $\begin{array}{l}\text { Claisy Maria } \\
\text { Marinho-Araujo }\end{array}$ & $\begin{array}{l}\text { Apresenta um panorama atualizado da Psicologia } \\
\text { Escolar enquanto campo de reflexão teórica, de } \\
\text { pesquisa e de intervenção profissional, } \\
\text { contextualizando estudos e reflexões que } \\
\text { orientam concepções, práticas e objetos de } \\
\text { investigação do psicólogo que escolhe a interface } \\
\text { entre Psicologia e Educação como objeto de } \\
\text { análise ou campo de atuação. }\end{array}$ \\
\hline 2 & $\begin{array}{l}\text { O que pode fazer o } \\
\text { psicólogo na escola? }\end{array}$ & $\begin{array}{l}\text { Albertina Mitjáns } \\
\text { Martínez }\end{array}$ & $\begin{array}{l}\text { Apresenta as possibilidades de atuação do } \\
\text { psicólogo na instituição escolar, dentro da } \\
\text { perspectiva e experiência de trabalho defendida } \\
\text { pela autora. Destaca a crescente produção } \\
\text { científica nacional e a gradual evolução das } \\
\text { formas de atuação dos psicólogos no país, em } \\
\text { função da escolha de novas concepções teórico- } \\
\text { epistemológicas e da sensibilização para as } \\
\text { complexas demandas da educação brasileira. }\end{array}$ \\
\hline 3 & $\begin{array}{l}\text { Perspectivas para a } \\
\text { promoção da } \\
\text { qualidade na } \\
\text { educação infantil: } \\
\text { Alguns instrumentos }\end{array}$ & Celia Vectore & $\begin{array}{l}\text { Apresenta alguns instrumentos desenvolvidos no } \\
\text { meio educacional e que podem facilitar a tarefa } \\
\text { do profissional de psicologia escolar na sua } \\
\text { atuação em instituições infantis. Discute os } \\
\text { resultados referentes a três estudos: 1) a avaliação } \\
\text { da instituição infantil feita pelas crianças; 2) a } \\
\text { escala de envolvimento dos professores; e 3) a }\end{array}$ \\
\hline
\end{tabular}

\footnotetext{
${ }^{2}$ O Instituto Nacional de Estudos e Pesquisas Educacionais Anísio Teixeira (INEP) é uma autarquia federal vinculada ao Ministério da Educação (MEC), cuja missão é promover estudos, pesquisas e avaliações sobre o Sistema Educacional Brasileiro com o objetivo de subsidiar a formulação e implementação de políticas públicas para a área educacional a partir de parâmetros de qualidade e equidade, bem como produzir informações claras e confiáveis aos gestores, pesquisadores, educadores e público em geral.
} 
entrevista lúdica como indicadora de quadros de estresse infantil em ambientes pré-escolares.

4 Psicologia Escolar e educação especial: Versões, inserções e mediações
Alexandra Ayach Anache

Apresenta as discussões que resultaram das pesquisas sobre os processos de intervenção nas redes de serviço de Educação Especial, analisando um conjunto de produções acadêmicas registradas no site da Fundação Coordenação de Aperfeiçoamento de Pessoal de Nível Superior (Capes) de 1994 a 2007, por agregar trabalhos que foram publicados como artigos em periódicos científicos, capítulos de livros e livros, que trouxeram contribuições sobre a temática em referência.

\section{A Psicologia na} educação superior: Ausências e percalços
Sônia Maria Rocha Analisa artigos publicados que tratam da Sampaio pesquisa e da intervenção do profissional psicólogo no âmbito da educação superior, extraindo daí, e de um olhar sobre as demandas dos setores juvenis que nele ingressam, ideias para a oxigenação e para a reorientação das práticas do campo psi. Defende a tese de que as universidades e seus públicos são espaços praticamente inexplorados pelos psicólogos que se debruçam sobre a área da educação.
6 Violência na escola: Uma reflexão sobre o bullying e a prática educativa
Herculano Ricardo Campos \& Samia Dayana Cardoso Jorge

Trata de uma revisão da literatura acerca da violência escolar, com ênfase no bullying, entendido enquanto violência psicológica, e a problematização da forma como a escola tem atentado e respondido ao aparecimento desse fenômeno no seu interior.

7 Psicologia Escolar e políticas públicas em educação: Desafios contemporâneos
Marilene Proença Rebello de Souza

Discute a importância de pesquisas na área de Psicologia Escolar no cotidiano escolar e o destaque dado ao analisar aspectos das relações escolares e dos processos educativos presentes na implementação de determinadas políticas públicas no campo da educação, com ênfase para as políticas de ciclo e de inclusão da pessoa com necessidades educativas especiais.
8 Professores e pesquisadores em Psicologia Escolar: Desafios da formação
Alacir Villla Valle Cruces

Discute as necessidades percebidas para a formação e preparo de profissionais em Psicologia aptos ao desenvolvimento de trabalhos eficientes e de relevância na área. A partir dos desafios propostos pelas Diretrizes Curriculares para os Cursos de Psicologia, surge a necessidade de implementar novos currículos que promovam o desenvolvimento, nos futuros psicólogos, de competências para esse tipo de atuação. 
9 Bibliografia comentada na área de Psicologia Escolar
Marisa Maria Brito Apresenta uma relação selecionada de livros, da Justa Neves artigos, dissertações e teses que evidenciam temas e pesquisas debatidos na última década na área da Psicologia Escolar. Consiste em um levantamento bibliográfico da produção nacional nessa área, contemplando publicações realizadas entre os anos de 1990 e 2007. A cada um dos trabalhos selecionados, seguem comentários condensados a partir dos textos originalmente elaborados pelos organizadores/autores das obras ou de resenhas já publicadas.

A variedade de perspectivas na diversidade de contextos e o surgimento de novos desenhos formativos também foram debatidos por Marinho-Araujo (2010a) nesse periódico, que realizou uma análise histórica da Psicologia Escolar no Brasil, levantando as concepções e práticas desenvolvidas pelos psicólogos ao longo das últimas três décadas. Neste capítulo, é apontado um panorama da área de Psicologia Escolar, confirmando sua especificidade enquanto campo de produção teórica, de pesquisa e atuação profissional. Ao discutir os paradigmas norteadores da Psicologia Escolar brasileira contemporânea e o compromisso social dos profissionais que atuam na área, a autora afirma que

As contribuições que a Psicologia Escolar pode e deve oferecer à sociedade nesse início de milênio, considerando seus múltiplos e diversificados campos de atuação, devem ter vínculos estreitos com uma postura crítica no interior das instituições educativas, com as transformações ideológicas e éticas que se fazem necessárias no âmbito da Psicologia e da Educação e com a sustentação e consolidação de intervenções coerentes com a natureza social e histórico-cultural dos sujeitos (p.31).

As intervenções profissionais do psicólogo devem pautar-se no domínio dos conhecimentos psicológicos e técnico-científicos, no desenvolvimento da sensibilidade para as questões que circundam os contextos sociais. A autora destaca, ainda, apoiada nas Diretrizes Curriculares Nacionais, o desenvolvimento da autonomia, a capacidade criativa, a tomada de decisões e resolução de problemas como outros indicadores que contribuem para a construção do perfil profissional.

O perfil profissional do psicólogo escolar, com imersão na escola, comparece e atualiza-se de diversas formas, pois considera a dinâmica de cada cenário, os agentes envolvidos, as políticas e relações intrínsecas a esse espaço, assim como a própria prática. Marinho-Araujo (2014a) teoriza acerca das dimensões e ações do trabalho desenvolvido pelo psicólogo na escola, destacando a realização do(a):

- Mapeamento institucional - análise do contexto escolar com o objetivo de "investigar convergências, incoerências, conflitos, avanços nas concepções e práticas expressas nos currículos, nos processos avaliativos e nos planejamentos" (p. 30). 
- Escuta psicológica - compreende a construção de "espaços de interlocução para circulação de sentidos das vozes institucionais, mediando processos relacionais e intersubjetivos de desenvolvimento e aprendizagens" (p. 30).

- Assessoria ao trabalho coletivo - consiste na "conscientização das concepções orientadoras das práticas pedagógicas que se refletem nos espaços e nas práticas institucionalizadas, bem como nas relações sociais e nos processos de gestão" (p. 30).

- Acompanhamento do processo de ensino e aprendizagem - subsidia o "professor acerca da importância de sua mediação nesse processo, favorecendo a disseminação de experiências educativas bem-sucedidas, ampliando as oportunidades de aperfeiçoamento em serviço de professores, coordenadores, gestores e outros atores educacionais" (p. 30).

Importante ressaltar que, em cada uma dessas dimensões, diversos são os procedimentos, ações e intervenções que podem ser realizados pelo psicólogo, seja nos níveis educacionais historicamente contemplados, seja naqueles preteridos ao longo desse processo histórico, especialmente o ensino médio e o ensino superior. A expansão da atuação do psicólogo escolar para essas áreas e a consolidação nos espaços já instituídos, com a proposta das dimensões acima apresentadas, pode representar um modelo de atuação e desenvolvimento profissional para os psicólogos escolares, tanto na rede pública, quanto na rede privada de ensino.

Considerando a escola como um lócus privilegiado de intervenção do psicólogo, Mitjáns Martínez (2010) questiona em um dos capítulos o que pode fazer o psicólogo na escola?, para além de discutir as formas de atuação tradicionais e emergentes do psicólogo na escola, a autora defende uma Psicologia Escolar que entende o sujeito como parte de um sistema constituído histórico e culturalmente, marcado por uma complexidade constitutiva e imbricado nos processos sociais, do qual a escola e as ações educativos são parte integrante. Ela entende que

a especificidade do trabalho do psicólogo na escola está fundamentalmente relacionada ao núcleo essencial da sua formação, entendido como o funcionamento psicológico humano, e às competências vinculadas a esse objeto. Essa formação permite-lhe um olhar específico e diferenciado sobre os processos subjetivos, sociais e individuais que se expressam no contexto escolar e, consequentemente, capacita-o para o delineamento de formas de atuação diferenciadas nesse contexto. (p.54).

Algumas dessas formas foram discutidas pela autora em outra produção teórica (Mitjáns Martínez, 2009). Ela propõe formas de atuação "emergentes", assim definidas por apresentarem uma configuração relativamente recente e estarem pouco difundidas no cotidiano escolar. Algumas dessas possibilidades emergentes são: o diagnóstico, análise e intervenção ema nível institucional, visando à otimização do processo educativo; a participação na construção, acompanhamento e avaliação da proposta pedagógica da escola; a participação no processo de seleção dos membros da equipe pedagógica e no processo de avaliação dos resultados do trabalho; a contribuição para a coesão da 
equipe de direção pedagógica e para sua formação técnica; a coordenação de disciplinas e de oficinas direcionadas ao desenvolvimento integral dos alunos; a contribuição para a caracterização da população estudantil com o objetivo de subsidiar o ensino personalizado; a realização de pesquisas diversas com o objetivo de aprimorar o processo educativo; a facilitação, de forma crítica, reflexiva e criativa da implementação das políticas públicas. A atuação do psicólogo escolar deve somar-se ao trabalho da equipe escolar, de forma conjunta, organizada e criativa, respeitando as particularidades de cada profissional, mas priorizando as ações coletivas.

Há que se considerar que no país existem diversos grupos e autores que estudam, pesquisam e publicam sobre a área da Psicologia Escolar, senda amplo o material disponível nos livros e periódicos brasileiros. A análise da interface entre a Psicologia e a Educação também tem sido objetivo de estudos para o entendimento da inserção e atuação do psicólogo escolar em instituições educacionais.

Visando dar maior ênfase à compreensão das ações teóricas e práticas que ligam a Psicologia ao campo educacional, em 2007, o Sistema Conselhos de Psicologia ${ }^{3}$ decidiu, na Assembleia das Políticas, da Administração e das Finanças (APAF), que o ano de 2008 seria dedicado à Educação. O propósito dessa ação era enfatizar a contribuição da Psicologia para a consolidação de uma educação para todos, "respaldada nos princípios do compromisso social, dos direitos humanos e do respeito à diversidade enquanto fundamento para uma efetiva inclusão social" (CFP, 2008, p. 11).

Uma das ações desenvolvidas pelo Sistema Conselhos foi a publicação de um compêndio (CFP, 2008) para subsidiar as discussões entre os psicólogos e demais profissionais do campo educativo, bem como de outros setores da sociedade. Foram definidos quatro eixos temáticos para nortear o debate, que são: 1) Psicologia, Políticas Públicas Intersetoriais e Educação Inclusiva; 2) Políticas Educacionais: legislação, formação profissional e participação democrática; 3) Psicologia e Instituições Escolares e Educacionais; e 4) Psicologia no Ensino Médio. Para cada eixo temático foram elaborados textos geradores, produzidos por profissionais especialistas nas diferentes áreas da Psicologia em interface com a Educação, visando fomentar o debate 4 e contribuir para o processo de construção de referências técnicas e políticas acerca da atuação do(a) psicólogo(a) no contexto escolar/educacional.

O texto gerador correspondente ao item 3 foi proposto por Guzzo (2008), intitulado Psicologia em instituições escolares e educativas: Apontamentos para um debate. Nesse capítulo, a autora defende que o papel do psicólogo deve ser pensado politicamente, para garantir a construção de uma ciência psicológica comprometida com todos os sujeitos que compõem a escola. Outro aspecto a ser apontado

\footnotetext{
${ }^{3}$ O Sistema Conselhos de Psicologia é formado pelo Conselho Federal de Psicologia (CFP) e pelos Conselhos Regionais de Psicologia (CRPs).

${ }^{4}$ A metodologia adotada pelo Sistema Conselhos para o Ano da Educação foi a realização de eventos regionais em seções, subsedes, escritórios e representações, por meio de oficinas, encontros, reuniões, seminários, palestras e mesas-redondas. As discussões sobre a política educacional brasileira e de cada estado visaram qualificar o psicólogo, técnica e politicamente, para melhor compreender a complexidade do sistema educacional atual, a partir do aprofundamento dos quatro eixos norteadores do Ano da Educação. (CFP, 2009)
} 
é a inserção do psicólogo no contexto escolar, como integrante do quadro de profissionais, o que favorece o acompanhamento e entendimento das questões que permeiam os processos educativos da criança e as relações com professores e gestores.

Uma análise de conjuntura faz-se necessária nesse momento, tendo em vista que a presença formalizada e institucionalizada do psicólogo escolar nas redes públicas de ensino ainda é bastante limitada. Para além da atuação no cotidiano da escola, deve ser objeto de interesse do psicólogo escolar o conhecimento e participação nas políticas públicas relacionadas à Educação, pois elas exercem impacto direto sobre a dinâmica institucional, sobre as relações dos diversos atores, além de contribuírem para o desenvolvimento da profissão no país. Não participar desse movimento significa manter o ciclo de formação, profissionalização e atuação à margem do desenvolvimento e consolidação do trabalho do psicólogo no campo educacional.

Nesse contexto de análise e reflexão deve-se perguntar: a serviço de qual projeto político está a Psicologia? Como pensar uma ciência crítica e comprometida socialmente? É preciso rever os fundamentos, redefinir os objetivos e ações profissionais para o "desenvolvimento pessoal e social na direção da libertação e da emancipação" (Guzzo, 2008, p. 60). A Psicologia Escolar, por meio de seus pesquisadores e profissionais, tem o compromisso de analisar, compreender e intervir nos diversos contextos educacionais em que se fizer presente, colaborando para os processos de transformação social e individual daqueles que compõem o cotidiano escolar.

Um exemplo desse compromisso de pesquisadores e profissionais são os trabalhos realizados em nível de mestrado e doutorado acadêmico nas universidades brasileiras, problematizando os diversos elementos que caracterizam a Psicologia Escolar. No Distrito Federal, a atuação de psicólogos escolares na rede pública de ensino do DF tem sido objeto de pesquisas de pós-graduação (Andrade, 2013; Araújo, 2006; Barbosa, 2008; Carvalho-Santos, 2014; Campos, 2001; Chagas, 2010; Gontijo, 2013; Libâneo, 2015; Mendes, 2011; Neves, 2001; Oliveira, 2007; Penna-Moreira, 2007; Pereira, 2011; Pinto, 2014; Rodrigues, 2011; Silva, 2015), que evidenciam o trabalho desenvolvido por esse profissional em equipes compostas também por pedagogos. Essas pesquisas acadêmicas versaram sobre diferentes temas, tais como a atuação institucional do psicólogo escolar, o trabalho junto aos gestores e ao coordenador pedagógico, a cultura do sucesso e as práticas exitosas, a formação continuada de psicólogos, a relação família-escola, além de estudos diretamente relacionados à estrutura e funcionamento desse serviço na SEDF.

A organização histórica e administrativa do serviço especializado foi investigada por PennaMoreira (2007), que evidenciou a necessidade da consolidação da identidade profissional do psicólogo que atua na rede pública, em consonância com os pressupostos teórico-metodológicos propostos pela Psicologia Escolar. A pesquisa, dentre outras questões, apontou que a formação continuada e a assessoria à prática profissional são requisitos fundamentais para o desenvolvimento das competências e perfil profissional dos psicólogos escolares da SEDF; sinalizou, ainda, que os documentos 
orientadores da EEAA deveriam estar coadunados e coerentemente embasados para guiar as práticas dos profissionais, em especial a do psicólogo escolar.

A partir desses achados, o estudo de Penna-Moreira (2007) sugeriu mudanças que ampliassem a visão e atuação do psicólogo escolar; algumas dessas sugestões foram implementadas no atual contexto do serviço, tais como:

- Reedição do documento orientador (OP) da EEAA que vigorava até então. Uma nova OP foi publicada em 2010, com diversos avanços teóricos e metodológicos que se constituem em referências até os dias atuais.

- Reestruturação da Coordenação Central. Nesse aspecto, o serviço apresentou avanços e retrocessos, pois, após ter sido criado e mantido o núcleo da Coordenação Central da EEAA ao longo de alguns anos, em 2015 ocorreu uma reestruturação da SEDF que agregou o trabalho das equipes com o núcleo de orientação educacional.

- Manutenção e ampliação da formação continuada. Apesar de ter sido formulada e realizada no ano de 2009, não houve nos anos seguintes, no âmbito da SEDF, um programa permanente e regular de formação para os psicólogos escolares da EEAA. A sugestão foi implantada no ano de 2015, com a realização de um curso promovido pela EAPE que atendeu cerca de 450 profissionais do serviço, com a proposição de manter essa iniciativa nos anos seguintes.

Outros trabalhos, como os de Barbosa (2008) e Silva (2015) discutiram amplas questões relacionadas ao trabalho do psicólogo escolar na EEAA, porém escolheram contextos específicos para a realização das pesquisas: Samambaia e Ceilândia, cidades do Distrito Federal. No trabalho de Barbosa (2008) é discutida a atuação institucional realizada pelos psicólogos, destacando as ações desenvolvidas junto aos professores e à análise dos processos intersubjetivos que ocorrem na escola. Uma das propostas do estudo foi o de organizar o trabalho da EEAA em três dimensões distintas, privilegiando e consolidando a ação institucional do psicólogo. A primeira dimensão refere-se ao trabalho intraequipe, em que o psicólogo atua conjuntamente com o profissional da sua equipe de apoio. A segunda é interequipes, em que o psicólogo se relaciona com os demais membros das Equipes da sua Coordenação Regional de Ensino. A terceira dimensão é a extraequipe, que prevê as ações dos psicólogos sendo desenvolvidas junto aos demais atores da escola. O que foi previsto ou sugerido pela pesquisadora já é uma realidade no atual contexto da EEAA e o psicólogo escolar tem atuado nas três dimensões propostas pelo estudo, escolhendo uma prática mais voltada para o coletivo da escola.

A pesquisa de Silva (2015) teve por contexto as Equipes Especializadas de Ceilândia, que contava com 29 (vinte e nove) psicólogos escolares atuantes no serviço. Como um dos objetivos do estudo foi verificar como esses profissionais têm se apropriado da Orientação Pedagógica, a pesquisadora realizou uma análise histórica, conceitual e metodológica das orientações pedagógicas da EEAA, bem como das concepções e pressupostos que embasaram as proposições de cada documento. 
Segundo as conclusões do estudo de Silva (2015) há um avanço teórico-conceitual nas concepções de desenvolvimento e de aprendizagem e na formulação das ações que o psicólogo pode e deve desenvolver no interior das instituições educacionais. Da mesma forma que nos estudos de PennaMoreira (2007) e Barbosa (2008), a formação continuada foi apontada como mecanismo de fortalecimento, consolidação e desenvolvimento profissional dos psicólogos escolares.

Ao pesquisar a cultura do sucesso e as práticas exitosas dos psicólogos da EEAA, Libâneo (2015) verificou que essas ações são compostas por aspectos que envolvem o planejamento, o desenvolvimento e a avaliação da atuação profissional. As práticas exitosas estão relacionadas às concepções e à atuação dos profissionais que compreendem a inter-relação entre o desenvolvimento dos sujeitos inseridos na escola e a própria dinâmica escolar, assim como as relações institucionais e os processos educativos que envolvem o que fazer do psicólogo (Martín-Baró, 1996). Dentre as questões apontadas na pesquisa, destaca-se a mudança de uma cultura do fracasso para uma cultura do sucesso e o desenvolvimento de competências profissionais por parte do psicólogo para o reconhecimento das potencialidades dos atores educacionais. Essa pesquisa amplia o campo de compreensão do psicólogo acerca da realidade escolar e da própria atuação, pois proporciona um redirecionamento da visão de trabalho e das ações institucionais, antes pautada no fracasso escolar e no atendimento às queixas escolares.

Os trabalhos de Pinto (2014) e Pereira (2011), também voltados ao Serviço Especializado de Apoio à Aprendizagem, buscaram compreender as concepções que embasavam as práticas pedagógicas e a atuação de psicólogos e pedagogos no atendimento aos alunos encaminhados com dificuldades de aprendizagem. As autoras concordam com a necessidade de se criar e alimentar espaços de reflexão dos profissionais da EEAA, aliada à formação teórica que ressignifique as concepções e práticas de psicólogos e pedagogos, assim como para os demais atores educacionais.

Chagas (2010), em parte de sua pesquisa de mestrado, realizou entrevistas apenas com duas psicólogas da CRE do Plano Piloto, concluindo que as profissionais pesquisadas apresentavam dificuldades na compreensão e implementação das diretrizes propostas na OP/2010 (GDF, 2010), especialmente na dimensão da atuação institucional. A autora, coadunando-se à diretriz para a EEAA, defende que o psicólogo pode oferecer um olhar diferenciado para a singularidade dos sujeitos, compreendendo a diversidade do desenvolvimento humano em uma atuação mediadora das relações interpessoais. Wanderer e Pedroza (2010), ao estudarem a atuação do psicólogo escolar na elaboração do Projeto Político Pedagógico da escola, apontam que ele deve estar imerso no cotidiano da escola, experimentando e fazendo parte das relações cotidianas da instituição. Essa mediação pressupõe um olhar voltado ao desenvolvimento individual e coletivo, visando a uma atuação mais consciente dos atores educacionais.

O trabalho de Mendes (2011) retratou a formação continuada dos psicólogos por meio de oficinas lúdicas e com a utilização de mediações estéticas, definidas como o "conjunto de elementos simbólicos qualitativamente diferenciados por sua dimensão sensível, lúdica, criativa, imaginária e 
fantástica, que se posicionam como um elo intermediário entre o sujeito e o contexto no qual está inserido" (p. 13). O estudo demonstrou a possibilidade de se promover processos reflexivos e de ressignificação da prática profissional de forma criativa, por meio de vivências lúdicas, como alternativa aos modelos formativos e de assessoria tradicionais.

A pesquisadora afirmou que as propostas formativas mais formais atingem processos de mediação de ordem racional, privilegiando os processos objetivos e práticos da ação, enquanto a mediação estética, por se tratar de uma interação criativa, possibilita o envolvimento afetivo do participante ou profissional em formação. Esse estudo aponta para outras possibilidades de formação continuada para os psicólogos escolares, em que possam pensar suas práticas profissionais de um outro lugar, mobilizando outros recursos, outras competências, para além das comumente focalizadas.

A formação inicial e a continuada devem ser observadas como importantes processos/espaços de desenvolvimento do psicólogo escolar, como apontado em diversos estudos (Asbahr, Martins \& Mazzolini, 2011; Marinho-Araujo \& Almeida, 2010; Marinho-Araujo, 2014a, 2014b; Medeiros \& Aquino, 2011; Oliveira \& Marinho-Araujo, 2009; Rossi \& Paixão, 2010), visando à consolidação de sua prática e identidade profissional. Pensar na identidade profissional do psicólogo escolar é refletir sobre o perfil esperado para este profissional, na forma como ele mobiliza "conhecimentos e saberes, da ciência e da experiência, em processos de construção e reconstrução de competências, visando se instrumentalizar para uma atuação ampliada a um coletivo profissional e a um cenário complexo" (Marinho-Araujo, 2014b, p. 173).

No contexto internacional, algumas pesquisas têm investigado o campo da Psicologia Escolar com o objetivo de conhecer as características, papéis, formação e interesses dos psicólogos escolares em diversos países, permitindo identificar a diversidade de práticas desenvolvidas por esses profissionais (Farrell, 2009; Filter, Ebsen, \& Dibos, 2013; Jimerson, Graydon, Farrell, Kikas, Hatzichristou, Boce \& Bashi, 2004; Jimerson, Graydon, Yuen, Lam, Thurm, Klueva, Coyne, Loprete \& Phillips, 2006; Jimerson, Graydon, Skokut, Alghorani, Kanjaradze \& Foster, 2008; Oakland \& Hatzichristou, 2014; Helgoth \& Sobansky, 2008; Thielking \& Jimerson, 2006). Essas pesquisas, realizadas em países como Austrália, China, Alemanha, Itália, Rússia, Geórgia, Emirados Árabes e no próprio Brasil, dentre outros, mostraram diferenças em relação ao perfil dos psicólogos, à formação dos profissionais e às atividades desenvolvidas nos diversos contextos. Para ilustrar essas informações, Jimerson et al. (2006) compararam dados de cinco países: Albania, Chipre, Estónia, Grécia e Inglaterra. Dentre as ações relatadas como sendo as principais desenvolvidas pelo psicólogo escolar, a avaliação psicoeducacional e aconselhamento estavam entre aquelas mais citadas. A terceira atividade mais importante relatada na pesquisa foi a consulta psicológica, que na China é a segunda ação profissional mais realizada.

Helgoth e Sobansky (2008) afirmaram que, entre os países, as diferenças ou predominância de algumas funções e papéis do psicólogo escolar variam de acordo com as demandas da população atendida por esses psicólogos. Para os autores, essa diferença no grau de importância e diversidade das 
práticas profissionais levanta a necessidade de analisar, tanto as especificidades e características locais, quanto olhar para além das fronteiras e observar experiências de outros países.

Outro aspecto observado é a necessidade do estabelecimento dos indicadores de atuação do psicólogo escolar, dada a diversidade de práticas existentes e a especificidade do papel do psicólogo frente a outros profissionais da Educação. Jimerson, Graydon, Curtis e Staskal (2007), destacaram que o psicólogo desempenha um papel crucial no contexto escolar, ressaltando algumas funções desse profissional: avaliação psicoeducacional, orientação aos alunos, criação e implementação de intervenções no contexto escolar, participação em programas de prevenção, atendimento a professores, pais e funcionários, realização de formação contínua e o cumprimento de tarefas administrativas.

Alguns estudos demonstraram que as principais atividades desenvolvidas pelos psicólogos escolar referem-se, ainda, a uma atuação mais voltada para a individualização, com destaque para a avaliação psicopedagógica e para o aconselhamento psicológicos dos estudantes (Jimerson et al., 2004; Jimerson et al., 2008; Jimerson et al., 2006). Esses relatos demostraram, ainda, que há uma predominância de psicólogos escolares atuando nos níveis iniciais de escolarização.

$\mathrm{O}$ tema das competências profissionais não é abordado diretamente nos artigos anteriormente citados, apesar de existirem referências acerca da atuação, das características profissionais e dos papéis desenvolvidos pelo psicólogo escolar. Considerando que os trabalhos apresentados propuseram uma ampla investigação acerca da presença e funções do psicólogo escolar em diversos países e contextos diferenciados, entende-se que é necessária maior investigação acerca das competências profissionais do psicólogo, relacionando-as ao seu perfil profissional.

O perfil profissional e o desenvolvimento das competências do psicólogo escolar, compreendidos a partir da perspectiva da Psicologia Histórico-cultural, serão objeto de análise do próximo capítulo. 


\section{Capítulo 3}

\section{Desenvolvimento Humano e Perfil profissional}

A Psicologia Histórico-cultural, representada por teóricos como Vygotsky, Leontiev e Luria (Leontiev, 1978a; Luria, 1990; Vygotsky, 1993, 1996, 2007) entende o desenvolvimento humano como um processo complexo, dialético e intimamente ligado às relações do sujeito no mundo. Partindo da compreensão de que os elementos filogenéticos constituem a base para o desenvolvimento do ser humano, essa abordagem discute o papel e a inter-relação dos processos ontogenéticos para explicar como o sujeito influencia e é influenciado pela natureza e pela vida social, impactando, inclusive, sua constituição biológica. Para Vygotsky (1995), um dos principais autores da abordagem históricocultural, o processo de desenvolvimento cultural e o desenvolvimento biológico fundem-se em um sistema, "formando o entrelaçamento de dois processos genéticos, porém essencialmente diferentes" (p. 39).

Vygotsky (2007) concebe duas linhas diferentes de desenvolvimento psicológico, divergindose qualitativamente quanto à sua origem: os processos elementares, de origem biológica; e as funções psicológicas superiores, de origem sociocultural. O autor defende a ideia de que "a história do desenvolvimento das funções psicológicas superiores seria impossível sem um estudo de sua préhistória, de suas raízes biológicas, e de seu arranjo orgânico" (Vygotsky, 2007, p. 42).

Leontiev (1978) considerava a dimensão biológica como uma primeira condição para o sujeito "tornar-se humano", mas que seria, na concretude do mundo objetivo e humanizado, transformado pela atividade do homem no passado e no presente, que essa condição seria possível. Para o autor

as propriedades biologicamente herdadas do homem não determinam as suas aptidões psíquicas. As faculdades do homem não estão virtualmente contidas no cérebro. O que o cérebro encerra virtualmente não são tais ou tais aptidões especificamente humanas, mas apenas a aptidão para a formação destas aptidões (p. 257).

Partindo da compreensão do ser humano como um sujeito histórico e constituído nos processos culturais, entende-se que a relação construída pelo sujeito com o meio e com seus pares influencia seu desenvolvimento biológico e social, em um processo histórico-cultural, onde se estabelecem as possibilidades de desenvolvimento da linguagem, da vida social, do trabalho e dos processos psicológicos. As vivências e os processos sociais mediados são internalizados por meio das funções mentais, em uma relação dialética da história individual e social de cada sujeito, conforme explana Vygotsky (2007)

Desde os primeiros dias do desenvolvimento da criança, suas atividades adquirem um significado próprio num sistema de comportamento social e, sendo dirigidas a objetivos definidos, são refratadas através do prisma do ambiente da criança. O caminho do objeto até a criança e desta até o objeto passa através de outra pessoa. Essa estrutura humana complexa é o 
produto de um processo de desenvolvimento profundamente enraizado nas ligações entre história individual e história social. (p. 19).

$\mathrm{Na}$ perspectiva histórico-cultural o conceito de social não deve ser entendido como algo determinista, em que as condições já se encontram pré-estabelecidas para o desenvolvimento humano. O ser humano desenvolve a condição humana, pois a natureza, por si só, não garante o desenvolvimento psicológico e cultural do sujeito, sendo necessária a ação do indivíduo no decurso do desenvolvimento histórico nesse contexto social (Leontiev, 1978). O homem interfere na natureza e a modifica, sofrendo interferência desta em seu processo de evolução, notadamente no desenvolvimento dos processos psicológicos superiores. Nesse processo de transformação de homem biológico em histórico-social, a cultura torna-se parte fundamental da constituição humana.

O elemento cultural na abordagem histórico-cultural considera os meios socialmente organizados pelos quais a sociedade estrutura os tipos de tarefas que os sujeitos enfrentam e os tipos de instrumentos disponíveis para realizar essas tarefas, sejam mentais ou físicos. Um dos instrumentos básicos constituídos pela humanidade para o seu desenvolvimento cultural é a linguagem, cujo papel na organização e desenvolvimento dos processos de pensamento foi discutido por Vygotsky em suas produções (Vygotsky, 1993, 1995; Vygotsky, Luria \& Leontiev, 1988).

As funções psíquicas superiores desenvolvem-se fundamentalmente nas relações sociais vivenciadas pelos sujeitos, na forma como o ser humano assimila e internaliza o mundo que está à sua volta. De acordo com Vygotsky (2007), a Psicologia não deve ter por objetivo estudar o desenvolvimento individual no coletivo, mas a transformação das relações sociais e coletivas em características pessoais dos sujeitos. Vygotsky (1993) entende que "todas as funções psíquicas superiores são processos mediados, e os signos constituem o meio básico para dominá-las e dirigi-las" (p.48).

O processo de desenvolvimento humano está relacionado e é movimentado pelo processo de aprendizagem, sem, porém, confundir-se com esse. O aprendizado é "um aspecto necessário e universal do processo de desenvolvimento das funções psicológicas culturalmente organizadas e especificamente humanas" (Vygotsky, 2007, p.118). A aprendizagem contribui e ativa o processo de desenvolvimento humano, pois, a partir dela, são desenvolvidas as características humanas não naturais, mas formadas historicamente (Vygotsky, Luria \& Leontiev, 1988).

Ao analisar a relação entre desenvolvimento e aprendizagem, destaca-se o conceito de mediação na obra de Vygotsky, definida como um processo de intervenção de um intermediário em uma relação, que deixa de ser direta e passa a ser mediada por esse elemento (Vygotsky, 2007; Oliveira, 2002). Leontiev (1978a) considera que

as conexões da criança com as coisas são mediadas pelas pessoas que a circundam: a mãe coloca a criança perto das coisas que lhe são atraentes, providencia para que fiquem perto dela, ou, talvez, tira-as dela. Numa palavra, a atividade da criança aparece, cada vez mais, como a 
realização de suas conexões com os seres humanos através das coisas, e conexões com as coisas através dos seres humanos. (p. 22.)

A mediação é fundamental para o desenvolvimento dos processos psicológicos superiores, diferenciando o homem dos outros animais e permitindo o desenvolvimento de atividades psicológicas intencionais, voluntárias e controladas pelo próprio sujeito. Vygotsky (2007) distinguiu dois tipos de elementos mediadores: os instrumentos e os signos. O instrumento é o elemento intermediário entre o homem e o objeto, ampliando as possibilidades de ação sobre a natureza. Ele é criado para uma finalidade específica e carrega consigo a função para a qual foi desenvolvido.

Em relação ao signo, Vygotsky (2007) considera-o como "um meio da atividade interna dirigido para o controle do próprio indivíduo" (p. 73), podendo representar ou expressar outros objetos, eventos ou situações. Os signos são compartilhados pelos membros de determinado grupo, possibilitando a estes a comunicação e aperfeiçoamento da interação social. Instrumentos e signos, segundo o autor russo, fazem parte da atividade mediada e provocam transformação nas funções psicológicas superiores. Vygotsky (2007) compreende que

O uso de meios artificiais - a transição para a atividade mediada - muda, fundamentalmente, todas as operações psicológicas, assim como o uso de instrumentos amplia de forma ilimitada a gama de atividades em cujo interior as novas funções psicológicas podem operar. Nesse contexto, podemos usar o termo função psicológica superior, ou comportamento superior com referência à combinação entre o instrumento e o signo na atividade psicológica. (p. 56).

Acerca da ação humana e o uso de instrumentos, Leontiev (1980) entende que o processo de apropriação da realidade é sempre ativo e que necessita da atividade do indivíduo para acessar a história acumulada em um objeto. $\mathrm{O}$ autor entende que

O instrumento é, pois, um objeto social, é produto de uma prática social, de uma experiência social de trabalho. Por conseguinte, o reflexo generalizado das propriedades objetivas dos objetos de trabalho, que cristalizam neles, é também o produto de uma prática individual. Devido a isso, o conhecimento humano mais simples, que se realiza diretamente em uma ação concreta de trabalho, com ajuda de uma ferramenta, não se limita a uma experiência pessoal de um indivíduo. Realiza-se na base da aquisição por parte da experiência da prática social. (p.65).

Essas práticas sociais acontecem nos mais diversos contextos e sob as mais variadas condições, mas considera-se a instituição escolar um espaço importante para o desenvolvimento humano e aquisição de conhecimentos culturalmente construídos. Nesse sentido, essa instituição é também um espaço de desenvolvimento dos profissionais que lá atuam e, em particular, do psicólogo escolar. Considerando que o processo de aprendizagem é ativo (seja por parte de quem ensina, seja por parte de quem aprende), todas as experiências vivenciadas, todas as relações compartilhadas no cotidiano escolar são importantes para a constituição profissional e pessoal de cada sujeito.

Pensando o contexto profissional do psicólogo escolar a partir das concepções históricoculturais, destaca-se que o desenvolvimento e a identidade desse profissional devem estar pautados a 
partir de um perfil que contemple a dinamicidade, a historicidade, as relações vividas e as subjetividades presentes. Conforme salienta (Marinho-Araujo, 2007), o perfil profissional assim entendido é pautado em uma construção histórica, pois que revela, de um lado, a expressão da história de vida da pessoa, de seus valores, vontades, necessidades, crenças e expectativas pessoais; e, de outro, as diversas relações de trabalho vinculadas a um momento social e cultural determinados. (p. 20)

Nessa perspectiva, não há como pensar o perfil profissional de forma estática, cumulativa ou relacionada unicamente à formação inicial do psicólogo, pois há que se considerar a diversidade e a constante transformação dos contextos profissionais e dos sujeitos que os compõem. Diversos processos de mediações são vivenciados no cotidiano da profissão e a própria profissão se reconfigura, na medida que os atores envolvidos reconstroem as relações e as produções materiais associadas a esses saberes e práticas.

O perfil profissional deve ser entendido como um conjunto de conhecimentos, competências, habilidades, características pessoais, valores, percepções e construções subjetivas desenvolvidos historicamente, aliado às características particulares da profissão que a diferenciam de outras e que, explicitado em determinado momento histórico e cultural, caracteriza a prática profissional do psicólogo escolar (Marinho-Araujo, 2007). Nessa perspectiva, o perfil profissional é visto de forma dinâmica, agregando elementos objetivos e culturalmente compartilhados, mas, também, constituindose nas relações e contextos históricos diferenciados em que atua o psicólogo escolar, ao longo da sua vida profissional.

O perfil profissional do psicólogo escolar na atualidade deve contemplar a disseminação de concepções críticas e dialéticas acerca do homem, discutindo e compreendendo o seu processo de desenvolvimento, a constituição de sua subjetividade e das relações de aprendizagem vividas por ele. Essa difusão é possível por ser o psicólogo escolar um membro efetivo da escola, atuando para a ressignificação das concepções de sujeito e de mundo, colaborando para uma nova compreensão dos processos de desenvolvimento e aprendizagem (Oliveira \& Marinho-Araujo, 2013; Marinho-Araujo, 2014). Nesse sentido, Marinho-Araujo (2010b) destacou que o psicólogo escolar deveria redirecionar o foco de compreensão da realidade educativa "para uma visão institucional, coletiva e relacional, contextualizada nos processos de subjetivação que dialeticamente re-significam os diversos atores e suas ações" (p. 27).

Acerca do debate sobre a formação inicial em Psicologia, no ano de 2004 foram instituídas as Diretrizes Curriculares Nacionais (DCN) para os cursos de Psicologia, aprovadas pelo parecer $n^{\circ}$ CNE/CES 0062/2004 da Câmara de Educação Superior do Conselho Nacional de Educação e, posteriormente, homologadas pelo Ministro de Estado de Educação. Ao analisar as DCNs e as discussões oriundas após sua publicação, Marinho-Araujo (2007) propôs um maior detalhamento e ampliação da compreensão das competências e habilidades sugeridas nas Diretrizes. 
A proposição da autora refere-se a uma categorização dos conhecimentos, saberes e habilidades necessários à atuação do psicólogo, neste caso destacando o profissional que atua em contextos educativos. As categorias apresentadas são as de ordem técnicas, pessoais, interpessoais e éticas, sendo previstas competências a serem desenvolvidas, além dos recursos e comportamentos esperados para a prática profissional do psicólogo.

Analisando criticamente as DCNs para a Psicologia, Marinho-Araujo (2007) sugeriu dilatar as discussões e reflexões de dois pontos fundamentais: ampliação do conceito de competências, visando maior clarificação acerca do perfil profissional desejado; e a diferenciação dos indicadores para as ênfases curriculares, com o objetivo de adequar o currículo à formação específica do psicólogo escolar. Esse é um dos desafios lançados à formação do psicólogo escolar pautada em um perfil profissional mais coerente com a realidade e as demandas da instituição escolar. Cruces (2010) corroborou essas reflexões, destacando a necessidade de construir novos projetos políticos-pedagógicos calcados nas Diretrizes Curriculares, que privilegiem uma formação mais abrangente, pluralista e fundamentada em bases teóricas e epistemológicas que sustentem práticas profissionais compromissadas com a realidade social na qual se insere o psicólogo.

Especificamente no Distrito Federal, o psicólogo escolar que atua na EEAA possui uma diretriz teórico-metodológica que orienta sua prática e prevê o desenvolvimento de diversas competências profissionais, como parte do perfil profissional desejado para o trabalho realizado nas unidades escolares. A partir das produções teóricas de Marinho-Araujo, acerca das competências do psicólogo escolar, a OP/2010 (GDF, 2010) destaca as seguintes características: (a) capacidade de análise, aplicação, reelaboração e síntese do conhecimento psicológico; (b) clareza acerca da relação entre as concepções teóricas sobre o conhecimento psicológico e o trabalho a ser desenvolvido; (c) postura crítica, lúcida e permanentemente reflexiva acerca do homem, do mundo e da sociedade, em função do contexto social no qual está inserido; (d) busca constante de conhecimentos e planejamento de estratégias interdisciplinares de que integrem e legitimem a intervenção psicológica; (e) comprometimento com o exercício de uma função político-social transformadora, exercendo-a eticamente no campo educacional; (f) domínio de teorias, de conceitos e de metodologias da Psicologia para intervenções psicológicas de caráter preventivo nos contextos educativos; (g) disponibilidade para socializar saberes, promover a circulação de informações, estimular a participação coletiva e o diálogo em equipes profissionais e multiprofissionais; (h) capacidade de buscar alternativas para a resolução de problemas, por meio de habilidades comunicativas e cooperativas; (i) disseminação de uma cultura de sucesso e de confiança nas ações humanas e profissionais; (j) habilidade para escutar, incentivar e orientar os professores para o desenvolvimento de estratégias relacionais e de ensino específicas para os alunos com queixas escolares; (k) habilidade para escutar e para orientar pais e familiares, em relação aos aspectos que interfiram direta ou indiretamente no desempenho escolar dos alunos; e (l) desenvolvimento de um compromisso ético e político com o movimento histórico de mudanças pessoais e coletivas. (p. 86). 
O perfil profissional e as competências propostas na OP (GDF, 2010) estão articulados com os conhecimentos teóricos e metodológicos produzidos pela literatura científica e diretamente relacionados à práxis profissional dos psicólogos escolares da Secretaria de Educação do DF. Dessa forma, tanto as produções e discussões teóricas têm impactado os estudos e a formação dos psicólogos da SEDF, quanto a própria realidade vivida por estes profissionais tem sido objeto de pesquisas, colaborando para o desenvolvimento da área no DF e no Brasil.

A respeito do perfil profissional do psicólogo escolar, Marinho-Araujo (2003) propôs uma categorização dos saberes e habilidades para o desenvolvimento de competências: saberes teóricos; saberes técnicos, saberes práticos, habilidades interpessoais, habilidades pessoais, habilidades éticas e habilidades estéticas. Entretanto, possuir habilidade, conhecimentos e capacidades não significa ser um profissional competente, pois, segundo Le Boterf (citado em Marinho-Araujo, 2003).

A competência não reside nos recursos (conhecimentos, capacidades...) a serem mobilizados, mas na própria mobilização desses recursos. A competência pertence à ordem do "saber mobilizar". Para haver competência é preciso que esteja em jogo um repertório de recursos (conhecimentos, capacidades cognitivas, capacidades relacionais...). (Le Boterf, citado em Marinho-Araujo, 2003, p. 100)

Por competência entende-se a capacidade do indivíduo de, diante de uma situação-problema, "mobilizar recursos e comportamentos disponíveis que deverão ser articulados aos pontos críticos identificados, para que seja possível tomar decisões e fazer encaminhamentos adequados e úteis ao enfrentamento da situação" (Marinho-Araujo, 2003, p. 96). A autora considera que essa concepção de competência se assenta numa perspectiva dinâmica e histórica do desenvolvimento do sujeito e das próprias competências, que requerem tempo para que as experiências sejam vivenciadas e analisadas, a fim de que o sujeito possa avaliar como e de que forma utilizar os conhecimentos, recursos e habilidades (p. 97).

Abordando o desenvolvimento de competências do psicólogo escolar, Marinho-Araujo (2005) destaca a importância de uma formação continuada e em serviço que privilegie conhecimentos técnicos, empíricos e posturas profissionais, além de possibilitar a construção de um perfil profissional capaz de sustentar ações competentes em diversos contextos de trabalho, integrando características práticas e reflexivas. Assim, o perfil do psicólogo escolar deve ser compreendido como construído histórica e dialeticamente, tanto por ações formativas planejadas e sistematizadas, quanto pela reflexão sobre a atuação no cotidiano escolar. A partir do diálogo entre pesquisas e práticas profissionais é possível definir um perfil para o psicólogo escolar que seja coerente com uma visão crítica da sua ação e dos espaços onde atua, assumindo as demandas e desafios postos no campo educacional (Cruces, 2005; Souza, Petroni, Dugnani, Barbosa \& Andrada, 2014).

Outras produções teóricas no campo da Psicologia Escolar têm discutido os papéis, funções, características profissionais dos psicólogos escolares, em variados contextos de atuação e envolvendo temáticas diferentes. Da atuação na educação básica ao ensino superior, esses estudos vêm discutindo 
as competências que poderiam ser desenvolvidas pelo psicólogo, seja em nível de graduação ou em um processo de formação continuada (Aquino, Lins, Cavalcante \& Gomes, 2015; Chiodi \& Facci, 2013; Dazzani, 2010; Freire \& Aires, 2012; Giongo \& Oliveira-Menegotto, 2010; Guzzo, Mezzalira \& Moreira, 2012; Medeiros \& Aquino, 2011; Nasciutti \& Silva, 2014; Petroni \& Souza, 2014).

Medeiros e Aquino (2011), ao analisarem a atuação de psicólogos em escolas públicas da cidade de Campina Grande/PB, apontaram, como característica de perfil profissional do psicólogo escolar, a capacidade de agir como mediador do processo educativo, considerando sua formação e contribuições teóricas. As autoras afirmaram que existe a necessidade do psicólogo firmar-se e ser reconhecido como parte da comunidade escolar, para melhor compreender e demonstrar suas possibilidades de atuação profissional.

Ao estudarem o processo de avaliação psicológica na rede pública de ensino no estado do Paraná e as competências do psicólogo diante dessa atividade, Chiodi e Facci (2013) consideraram ser necessária uma avaliação pautada pela mediação e que analisasse o desenvolvimento do estudante de uma forma mais prospectiva. É destacada pelas autoras a importância de o psicólogo escolar considerar os fatores que envolvem o cotidiano escolar, assim como as relações institucionais e pedagógicas referentes ao processo de ensino e aprendizagem.

Dazzani (2010), ao discutir a educação inclusiva, relacionou ao perfil profissional do psicólogo escolar a ações que contemplassem a prevenção e promoção do bem-estar na escola, atuando para a diminuição do fracasso escolar e de outros fatores que pudessem inibir as potencialidades dos estudantes. Como parte do perfil esperado para o psicólogo, a autora afirmou a necessidade desse profissional integrar equipes e grupos de trabalho multidisciplinares, discutindo com outros profissionais aspectos do desenvolvimento da criança.

Analisando as relações estabelecidas pelo psicólogo escolar com outros atores educacionais, Petroni e Souza (2014) destacaram a importância do psicólogo desenvolver, como competência profissional, a capacidade de trabalhar em parceria dentro da escola, seja com gestores, professores, alunos, pais e demais funcionários. O trabalho em parceria permitiria, segundo as autoras, a consecução de ações de formação profissional e de recursos humanos, no âmbito da formação inicial e continuada. O foco seria, assim, a promoção de ações coletivas que colaborassem, dentre outros aspectos, com a ampliação da consciência de gestores e demais atores sobre os seus papéis na escola.

Ao discutir a contribuição da Psicologia Escolar na prevenção e no enfrentamento do bullying, Freire e Aires (2012) relataram que o psicólogo escolar tem que ser capaz de analisar, refletir e provocar reflexões nos atores educacionais acerca das interações e conflitos que envolvem a dinâmica escolar. As autoras destacam que, para o psicólogo alcançar esses objetivos, deve desenvolver a escuta psicológica e ressignificar os processos relacionais existentes, assessorando as práticas educativas e instrumentalizando a equipe com estudos e capacitações que favoreçam as reflexões sobre o fenômeno do bullying. 
Ao analisar a prática de estágio supervisionado em Psicologia de uma instituição de Ensino Superior de Minas Gerais, Nasciutti e Silva (2014) sinalizaram para a necessidade de o psicólogo escolar desenvolver, desde sua formação inicial, um perfil profissional crítico, pautado nas contribuições da Psicologia Histórico-Cultural. O estudo mostrou a importância da atividade prática e dos estudos teóricos para o processo de apropriação conceitual e técnica por parte do psicólogo em formação, compreendendo que são processos inter-relacionados.

O trabalho de Guzzo, Mezzalira e Moreira (2012), a respeito da inserção do psicólogo escolar nas políticas públicas educacionais, destacou a necessidade desse profissional desenvolver uma formação pautada em discussões políticas e de práticas voltadas à construção da profissão. O psicólogo precisaria, assim, participar de fóruns, audiências e demais espaços que discutissem as políticas educacionais, visando ampliar a inserção desse profissional no sistema público. Além disso, o psicólogo deveria assumir um compromisso ético-político com a mudança da realidade social em que atua.

Em um estudo realizado em quatro escolas municipais da região metropolitana de Porto Alegre/RS, Giongo e Oliveira-Menegotto (2010) também enfatizaram a necessidade de o psicólogo assumir o compromisso crítico com as mudanças no contexto escolar, privilegiando ações construídas de forma coletiva. A capacidade de inserir-se no cotidiano escolar, de participar e integrar-se à equipe foi a principal característica apontada pelas autoras, como maneira de consolidar a identidade profissional do psicólogo escolar.

O estudo de Aquino, Lins, Cavalcante e Gomes (2015), realizado em escolas públicas de João Pessoa/PB, discutiu as concepções e práticas de psicólogos escolares junto a docentes, destacando a relevância da atuação junto aos professores, especialmente quando trabalhadas as questões dos processos de ensino e aprendizagem dos estudantes. As autoras destacaram a necessidade do psicólogo investir no desenvolvimento de suas competências teóricas, por meio de formação continuada, além de envolver-se politicamente nas ações que participa.

O perfil profissional do psicólogo escolar, associado ao desenvolvimento de competências, mostra-se complexo, dinâmico, desafiador e marcado historicamente, tendo a instituição escolar como principal locus de atividade do psicólogo. Marinho-Araujo (2003) defende a necessidade de o psicólogo escolar desenvolver competências adequadas e eficazes visando a uma melhor atuação no contexto escolar, para lidar com os inúmeros fenômenos enfrentados em sua realidade. A formação do perfil profissional deve contemplar, dentre outros aspectos, a transformação das concepções cristalizadas acerca do desenvolvimento e aprendizagem humanos, a mudança de foco do fracasso para o sucesso escolar e a realização de intervenções que visem o bem-estar dos sujeitos (Guzzo, 2001; MarinhoAraujo, 2003, 2014).

Nesta pesquisa, buscou-se conhecer o perfil profissional do psicólogo escolar das Equipes Especializadas de Apoio à Aprendizagem da SEDF e as competências necessárias à atuação profissional. Os pressupostos da Psicologia Histórico-cultural e da Psicologia Escolar subsidiarão a análise das informações recolhidas dos psicólogos entrevistados. Apresentam-se, a seguir, as questões 
mobilizadoras da pesquisa e os objetivos propostos para a investigação dos indicadores de perfil dos psicólogos escolares que atuam nas Equipes Especializadas de Apoio à Aprendizagem. 


\section{Capítulo 4}

\section{Metodologia}

Neste capítulo são apresentados os objetivos geral e específicos que guiaram os momentos da pesquisa, desde a recolha das informações por meio das entrevistas às discussões e análises realizadas posteriormente. Em seguida, são explicitados os pressupostos teórico-metodológicos que orientaram essa investigação e apresenta-se a caracterização do contexto e dos participantes. Ao final, são explicados os procedimentos de construção, de interpretação e de análise das informações que constituem os achados desta pesquisa de mestrado.

\section{Objetivos}

\section{Objetivo geral}

O objetivo geral da pesquisa foi investigar os indicadores de perfil profissional de psicólogos escolares das Equipes Especializadas de Apoio à Aprendizagem da Secretaria de Educação do DF.

\section{Objetivos específicos}

- Levantar, a partir da perspectiva dos psicólogos, as características para a construção dos indicadores do perfil do psicólogo escolar das Equipes Especializadas de Apoio à Aprendizagem da Secretaria de Educação do DF.

- Apresentar uma proposta de perfil profissional, considerando a categorização de indicadores, que podem ser desenvolvidos pelo psicólogo escolar.

\section{Pressupostos Teórico-Metodológicos}

A pesquisa científica de base qualitativa caracteriza-se, fundamentalmente, pela abordagem interpretativa sobre o mundo, o que leva seus pesquisadores a estudarem os fenômenos em seus cenários naturais, buscando apreender os significados que as pessoas conferem a eles (Denzin \& Lincoln, 2006). De acordo com Vieira e Zouain (2005), a pesquisa qualitativa confere importância fundamental aos depoimentos dos atores envolvidos, aos discursos e significados transmitidos por eles. Como parte do processo de investigação, busca-se a descrição detalhada dos eventos e dos elementos que os envolvem.

A pesquisa qualitativa fundamenta-se em abordagens teóricas que consideram a subjetividade dos pesquisadores e sujeitos estudados como parte integrante do processo investigativo. Dessa forma, as reflexões, observações, impressões e sentimentos dos pesquisadores tornam-se informações de pesquisa, constituindo parte da interpretação (Flick, 2009). Nesse tipo de pesquisa espera-se, por parte do investigador, certo grau de reflexibilidade sobre os temas de estudo e uma apropriação às questões e métodos escolhidos no fazer científico (Flick, 2009). 
A investigação qualitativa entende que o fenômeno pode ser melhor compreendido no contexto em que ocorre e do qual é parte integrante, devendo ser analisado em uma perspectiva relacional. Assim, o pesquisador vai a campo com o objetivo de compreender a dinâmica do objeto em estudo, a partir da visão das pessoas nele envolvidas, considerando os principais elementos relacionados a esse contexto.

O termo qualitativa evidencia um destaque acerca das qualidades das entidades ou objetos pesquisados, bem como dos processos e significados que não são mensurados no campo da pesquisa, em termos de quantidade, volume ou frequência, por exemplo. Denzin \& Lincoln (2006) consideram que

Os pesquisadores qualitativos ressaltam a natureza socialmente construída da realidade, a íntima relação entre o pesquisador e o que é estudado, e as limitações situacionais que influenciam a investigação. Esses pesquisadores enfatizam a natureza repleta de valores da investigação. Buscam soluções para as questões que realçam o modo como a experiência social é criada e adquire significado. (p. 23).

Segundo Flick (2009), as pesquisas qualitativas consistem em um conjunto de ações interpretativas que tornam o mundo visível e o transformam, fazendo dele uma série de representações. Nesse tipo de pesquisa, destaca-se a postura interpretativa do pesquisador e o estudo das coisas em seus contextos naturais, buscando a compreensão dos fenômenos em termos dos sentidos que as pessoas lhes atribuem. Compreende-se que a subjetividade do pesquisador e dos participantes fazem parte do processo de investigação e seus métodos pressupõem a interação do investigador com o campo e os seus integrantes, como parte explícita da produção do saber, privilegiando a reflexão como parte do processo dessa produção. A análise de diferentes perspectivas permite uma ampliação do olhar sobre o objeto e sobre as relações deste com os contextos nos quais se insere.

Günther (2006) afirma que na pesquisa qualitativa são necessárias as escolhas de instrumentos e procedimentos específicos de investigação, garantindo sua flexibilidade e adaptabilidade diante do objeto investigado e em função de suas especificidades, evitando-se, assim, o uso de instrumentos e procedimentos padronizados. Existe uma grande variedade de métodos utilizados nesse tipo de investigação, cada um partindo de diferentes premissas em busca de objetivos distintos, tais como o estudo de caso, entrevistas, observações, diários, análise de conteúdo, análise do discurso, etnografia, netnografia, focus group, dentre outros (Denzin \& Lincoln, 2006; Flick, 2009).

A pesquisa qualitativa de base histórico-cultural pressupõe que o pesquisador, a partir das escolhas teórico-metodológicas que utiliza, tenha um papel ativo no transcurso de toda a investigação, implicando-se na construção do conhecimento e na relação com os participantes da pesquisa, compreendendo o contexto em sua dimensão social, cultural e histórica. A partir desses pressupostos, entende-se a realidade como um fenômeno complexo, dinâmico e dialético, onde privilegia-se a natureza interativa na investigação científica (Vygotsky, 1996, 2007). O processo relacional na pesquisa é valorizado e as ações do pesquisador podem influenciar o objeto investigado na medida em que considera, da mesma forma, o participante como agente na construção das informações. 
A pesquisa deve ser compreendida como uma atividade humana mediada socialmente, como uma prática social, política, ética e estética que visa à criação de um conhecimento novo, produzido e apropriado com inventividade e rigor científico, que implica a transformação de algo, quer seja nos sujeitos envolvidos, quer seja nos objetos pesquisados. (González-Rey, 2005; Madureira \& Branco, 2001; Molon, 2008). Essa perspectiva entende que os fatos e situações que se apresentam na escola e em outros espaços sociais precisam ser compreendidos, explicados e influenciados pelos profissionais de modo a impactar a realidade, transformando a prática instituída. Isso é possível na medida em que o ser humano é visto como constituído em uma relação dialética e histórica com seus pares e com o mundo.

Para Vygotsky (1995), "toda apresentação fundamentalmente nova dos problemas científicos, conduz inevitavelmente a novos métodos e técnicas de investigação. $\mathrm{O}$ objeto e o método de investigação mantém uma relação muito estreita" (Vygotsky, 1995, p. 47). Ele entende que a definição do método é uma das principais tarefas na investigação científica, na medida em que é elaborado concomitantemente ao problema de pesquisa, em uma relação dialética para a compreensão do objeto pesquisado. O método, dessa forma, assume o papel de ferramenta e resultado da investigação e ganha importância no desenvolvimento do próprio processo e dos diferentes fatores que o influenciam (Freitas, 2002).

Para a implementação dessa abordagem metodológica, Vygotsky $(1995,1996)$ trata de três princípios orientadores e que permitem a melhor compreensão da realidade investigada. O primeiro princípio é foco nos processos, o que implica considerar as mudanças no desenvolvimento humano e nas relações estabelecidas pelo sujeito em suas práticas sociais, sendo necessário, de igual forma, o resgate da análise da história do indivíduo. O segundo é o caráter explicativo, e não meramente descritivo, que a pesquisa ou investigação científica deve ter, quer dizer, é preciso que ocorra a explicação das relações internas constitutivas dos fenômenos humanos. O terceiro princípio refere-se aos chamados comportamentos automatizados (fossilizados) que, em função do processo de desenvolvimento humano, devem ser analisados dentro de uma dimensão histórica e contextualizados pelas relações sociais das quais fazem parte. De acordo com o autor, em uma pesquisa, abranger

o processo de desenvolvimento de uma determinada coisa, em todas as fases e mudanças - do nascimento à morte -, significa, fundamentalmente, descobrir sua natureza, sua essência, uma vez que "é somente em movimento que um corpo mostra o que é". Assim, o estudo histórico do comportamento não é um aspecto auxiliar do estudo teórico, mas sim sua verdadeira base. (Vygotsky, 2007, p. 68).

Estudar o componente histórico na pesquisa qualitativa envolve a compreensão explicativa das relações que constituem o fenômeno estudado, não sendo suficiente apenas a descrição desses processos (Vygotsky, 1996). Para o autor russo, é necessário estabelecer um vínculo entre vários fatos ou grupos de fatos, relacionar uma série de fenômenos a outros, de forma a entender as múltiplas determinações que constituem o objeto estudado. 
Em articulação com a Psicologia Histórico-Cultural, a construção do conhecimento e o processo analítico dessa pesquisa fundamentaram-se nos três princípios básicos da Epistemologia Qualitativa proposta por González Rey (1999; 2002; 2005). O primeiro princípio é a compreensão do caráter construtivo-interpretativo do conhecimento, o que implica compreendê-lo como produção permanente e não como uma apropriação reduzida de uma realidade previamente apresentada. O segundo princípio é a defesa da legitimação do singular como fonte de produção do conhecimento científico, em que as concepções, saberes e experiências dos indivíduos são significativamente importantes nessa produção. O terceiro princípio consiste em entender a pesquisa como um processo de comunicação e diálogo, caracterizado pela construção de um espaço de interlocução e de recolha das informações investigadas a partir da relação pesquisador-pesquisado.

A construção e a análise das informações se dão pelas falas e expressões dos sujeitos pesquisados, produzidas por meio dos instrumentos utilizados nos momentos empíricos. Essas informações possibilitam a elaboração de indicadores de sentidos a partir dos quais são construídas as categorias na pesquisa. Por outro lado, as informações não se mostram tão claras para o pesquisador, não estão presentes apenas nas expressões dos sujeitos da pesquisa, em suas falas e escritas. Para González Rey (2005), os sentidos subjetivos estão

na qualidade da informação, no lugar de uma palavra em uma narrativa, na comparação das significações atribuídas a conceitos distintos de uma construção, no nível de elaboração diferenciado no tratamento dos temas, na forma com que se utiliza a temporalidade, nas construções associadas a estados anímicos diferentes, nas manifestações gerais do sujeito em seus diversos tipos de expressão etc. (p. 116).

A partir dessa compreensão, a construção do conhecimento na pesquisa se dá pela análise das conversações e das respostas dos participantes aos instrumentos, dando ao pesquisador a possibilidade de levantar indicadores que, organizados em categorias, constituem a base para a investigação. Esses indicadores devem ser confrontados com outros, provenientes de um mesmo instrumento ou do conhecimento produzido na área, a fim de que sejam analisados em um processo construtivointerpretativo permanente de elaboração do conhecimento.

Na perspectiva da Epistemologia Qualitativa (González Rey, 1999, 2002, 2005, 2010), a apreensão das significações estabelece-se a partir da compreensão dialética das relações que constituem a realidade, em um amplo conjunto de elementos objetivos/subjetivos que configuram e caracterizam seu movimento. Nesse aspecto, a compreensão dos sentidos e significados dos participantes não se reduz a uma técnica, mas a um procedimento que considera as mediações históricas, sociais e as contradições que perpassam o sujeito e a realidade da qual faz parte, apresentando possibilidades de atingir, por meio da análise e da interpretação, o processo de constituição de significações. Vygotsky (2001), ao discutir a relação entre sentidos e significados, afirma que

o sentido de uma palavra é a soma de todos os fatos psicológicos que ela desperta em nossa consciência. Assim, o sentido é sempre uma formação dinâmica, fluida, complexa, que tem 
várias zonas de estabilidade variada. O significado é apenas uma dessas zonas do sentido que a palavra adquire no contexto de algum discurso e, ademais, uma zona mais estável, uniforme e exata. (p. 465).

Os sentidos são compreendidos como produtos singulares das relações sociais, retratando o modo como o sujeito internaliza as informações e as vivências do seu meio cultural, sempre de forma dialética, ressignificando as diversas experiências de seu cotidiano. O meio onde vive o indivíduo encontra-se repleto de significados culturais, que são apreendidos com a participação de variados mediadores e instrumentos. Nesse processo relacional com o mundo, a subjetividade humana desenvolve-se e cada vez mais o sujeito se "individualiza", constituindo sua identidade e personalidade. Se, por um lado, os significados compartilhados socialmente remetem a uma zona mais estável, uniforme, os sentidos possuem um caráter simbólico, sendo um possibilitador da relação homem/mundo (Costas \& Ferreira, 2011).

Nesta pesquisa, buscou-se investigar os significados e os sentidos que os psicólogos escolares das Equipes Especializadas de Apoio à Aprendizagem constroem acerca do perfil e das competências profissionais para a atuação na SEDF.

\section{Contexto de Pesquisa}

O Distrito Federal está localizado na Região Centro-Oeste do Brasil e sua área é de 5.789,16 $\mathrm{km}^{2}$, equivalendo a $0,06 \%$ da superfície do país. Apresenta como limites naturais o rio Descoberto a oeste e o rio Preto a leste. Limita-se, ao norte, com os municípios de Planaltina, Padre Bernardo e Formosa; ao sul, com Santo Antônio do Descoberto, Novo Gama, Valparaíso de Goiás e Cristalina, todos do Estado de Goiás; a leste, com o município de Cabeceira Grande, pertencente ao Estado de Minas Gerais e Formosa pertencente ao Estado de Goiás; e, a oeste, com os municípios de Santo Antônio do Descoberto e Padre Bernardo, também de Goiás. A população estimada é de 2.852 .372 habitantes e possui 31 Regiões Administrativas, incluindo a capital, Brasília (GDF, 2015).

Além das Regiões Administrativas que compõem o Distrito Federal, também é considerada a Região Integrada de Desenvolvimento de Brasília (RIDE-DF) que, desde 2013, passou a ser chamada de Região Metropolitana. No campo educacional, o Distrito Federal recebe grande demanda de estudantes oriundos das cidades do entorno, que se matriculam na rede pública de ensino e impactam as estatísticas educacionais do DF. Essas cidades são aquelas fronteiriças ao Distrito Federal, tais como Novo Gama, Pedregal, Valparaiso, Águas Lindas, Santo Antônio do Descoberto, Planaltina de Goiás, Cidade Ocidental e Luziânia.

Vários são os contrastes e as desigualdades sociais quando se comparam as Regiões Administrativas entre si. Algumas delas como Plano Piloto, Lago Sul, Sudoeste, Noroeste, Águas Claras têm Índice de Desenvolvimento Humano Municipal $\left(\mathrm{IDHM}^{5}\right)$ na faixa mais alta da classificação, entre

\footnotetext{
${ }^{5}$ A escala do IDHM varia de 0 a 1 - quanto mais próximo de 1 , mais desenvolvido é o município.
} 
0,955 e $0,957^{6}$. Por outro lado, a região da Estrutural ficou no último lugar da lista, próximo aos índices de Recanto das Emas, Samambaia, São Sebastião e Sobradinho 2, que empatam com o mesmo valor: 0,616. A dimensão cujo índice mais cresceu no DF, entre 2000 e 2010, foi o da escolaridade: subiu de 0,516 para 0,701 , em um aumento de 0,185 . A contribuição da escolaridade para o IDMH, que era de apenas 25\% em 2000, passou para 29\%. A área rural de Planaltina de Goiás ficou com o menor índice de escolaridade registrado: obteve pontuação igual a 0,481, considerada baixa. Águas Claras ficou com a melhor posição, com 0,936 (IPEA, 2014).

Em 2014, o Distrito Federal foi a primeira unidade da Federação a receber o Selo de Território Livre do Analfabetismo do Ministério da Educação ${ }^{7}$. O título é um reconhecimento às localidades que atingem 96\% de alfabetização, segundo o censo do Instituto Brasileiro de Geografia e Estatística (IBGE); o DF atingiu o índice de 96,5\%. Na capital, mais de um milhão (51,35\% da população acima de 10 anos de idade) de pessoas dedicam pelo menos uma década da vida ao estudo. Cerca de 18,57\% da população, 424 mil pessoas, estudam por mais de 15 anos no Distrito Federal, enquanto o índice em São Paulo é de 11,25\% da população e 11,24\% no Rio de Janeiro (Anuário do DF, 2014).

No âmbito das políticas educacionais, a Secretaria de Educação do Distrito Federal (SEDF) tem a função de coordenar o sistema público e privado de ensino do DF. Após uma reestruturação administrativa em 2015, em função da junção de duas secretarias de governo, a SEDF passou a ser denominada Secretaria de Educação, Esporte e Lazer do Distrito Federal ${ }^{8}$, por meio do Decreto $\mathrm{n}^{\circ}$ 36.828, de 22 de outubro de 2015 (GDFc, 2015).

A SEDF é composta por 658 escolas, 581 localizadas em áreas urbanas e 77 em zonas rurais, divididas nas diversas etapas e modalidades de ensino e distribuídas em 14 Coordenações Regionais de Ensino (CRE). As CREs são as unidades da SEDF responsáveis por gerir as atividades pedagógicas e administrativas das escolas em cada uma das seguintes cidades do Distrito Federal: Brazlândia, Ceilândia, Gama, Guará, Núcleo Bandeirante, Paranoá, Planaltina, Plano Piloto, Recanto das Emas, Samambaia, Santa Maria, São Sebastião, Sobradinho e Taguatinga. Pertencem ao quadro de profissionais da SEDF 41.821 servidores públicos, sendo 30.442 da carreira magistério e 11.379 da carreira assistência, esta última caracterizada por prestar apoio técnico e administrativo no âmbito das unidades escolares (GDFa, 2015). Atualmente, estão matriculados na rede pública de ensino 470.324 alunos, distribuídos da seguinte forma: 35.209 na creche e pré-escola; 291.601 no ensino fundamental;

\footnotetext{
${ }^{6}$ Para fins de comparação, apresenta-se o IDHM de algumas capitais brasileiras: São Paulo - 0,714, Belém 0,621, Belo Horizonte - 0,682, Curitiba - 0,698, Rio de Janeiro - 0,686, Bahia - 0,636, Porto Alegre - 0,685, Manaus - 0,585. O IDH do Brasil é 0,744.

${ }^{7}$ O Selo de Território Livre do Analfabetismo do Ministério da Educação é conferido a municípios que atingirem mais de $96 \%$ de alfabetização em suas redes. Os certificados se dividem em: Ótimo Desenvolvimento Educacional para aqueles que tenham Índice de Desenvolvimento da Educação Básica (IDEB) igual ou superior a seis; e Bom Desenvolvimento Educacional, para estados e municípios com IDEB superior ou igual a cinco e inferior a seis. Disponível em http://portal.mec.gov.br/arquivos/Bk_pde/selo.html.

${ }^{8}$ Por se tratar de uma mudança recente e considerando que esta pesquisa de mestrado iniciou-se antes da reestruturação citada, utilizaremos nesta dissertação o nome Secretaria de Educação do DF e sua respectiva sigla SEDF.
} 
81.300 no ensino médio; 5.039 na educação profissional; 51.179 na educação de jovens e adultos; e 5.996 na educação especial.

\section{Aspectos Históricos da Psicologia Escolar na SEDF}

O primeiro registro institucionalizado da Psicologia Escolar no Distrito Federal é de 1968, com a criação do Atendimento Psicopedagógico, que acontecia na Escola Parque 307/308 Sul. Nessa época, o foco dos atendimentos concentrava-se no diagnóstico psicopedagógico de crianças que apresentavam fracasso escolar ou algum tipo de necessidade especial (Marinho-Araujo, Neves, Penna-Moreira \& Barbosa, 2011; Penna-Moreira, 2007).

No ano de 1971, em função do convênio entre a Secretaria de Educação, antes denominada Fundação Educacional, e a Secretaria de Saúde, o atendimento psicopedagógico foi transferido para o COMPP (Centro de Orientação Médico-Psicopedagógico). Além de possuir o trabalho profissional do psicólogo e do pedagogo, esse atendimento passou a contar com a atuação multidisciplinar de pediatras, psiquiatras e fonoaudiólogos (Barbosa, 2008; Chagas \& Pedroza, 2013; GDF, 2010; Marinho-Araujo, Neves, Penna-Moreira \& Barbosa, 2011; Neves, 2001; Penna-Moreira, 2007).

Em função da grande demanda de encaminhamentos e a dificuldades de atendimento pelo COMPP, aconteceu a criação de uma Equipe de Diagnóstico e Avaliação Psicopedagógica do Ensino Especial, em 1974, que funcionava no Centro de Ensino Especial no 01 de Brasília. O trabalho dessa equipe consistia na avaliação e atendimento das crianças da rede pública de ensino do DF que apresentavam necessidades especiais (Marinho-Araujo et a., 2011; Neves, 2001).

A publicação das Diretrizes Pedagógicas no 5, de 1981, chamada de O Atendimento do Aluno com Deficiências Específicas de Aprendizagem, foi uma resultante das reformulações conceituais acerca do estudante que apresentava dificuldades de aprendizagem. Na ocasião, o aluno que apresentava dificuldades de aprendizagem não seria mais considerado como portador de distúrbios funcionais, relacionado essas dificuldades ao contexto social e cultural e a fatores psicológicos (Neves, 2001).

Essa mudança conceitual possibilitou, no ano de 1987, a implementação das Equipes de Atendimento Psicopedagógico (ATPP), que realizavam o atendimento aos alunos do ensino regular que apresentavam dificuldades de aprendizagem. Essas equipes funcionavam em espaços cedidos por algumas escolas e já eram compostas, naquele momento, por um pedagogo e por um psicólogo. As equipes que atendiam os estudantes do ensino especial eram chamadas de Equipes de Diagnóstico/Avaliação Psicopedagógica do Ensino Especial, cuja função consistia, basicamente, na avaliação das crianças com suspeita de possuírem algum tipo de necessidade especial (Barbosa, 2008).

Nesse processo histórico, ganha relevância a publicação de documentos orientadores e legislações específicas sobre o Serviço Especializado de Apoio à Aprendizagem, tais como portarias e diretrizes técnico-pedagógicas. Conforme mostra a Figura 1, em 1992 foram publicadas as primeiras Orientações Pedagógicas (OP) do serviço, intituladas OP nº 20 (Ensino Regular) e OP nº 22 (Ensino 
Especial), sendo reeditadas em 1994. Esses documentos apresentavam diretrizes para a atuação do psicólogo escolar e do pedagogo no âmbito da SEDF (Penna-Moreira, 2007; Silva, 2015).

No ano de 2004 aconteceu a fusão das Equipes de Atendimento Psicopedagógico com as Equipes de Diagnóstico/Avaliação Psicopedagógica do Ensino Especial, sendo denominadas de Equipes Especializadas de Atendimento e Apoio à Aprendizagem (EAAA). Essas equipes foram inseridas nas escolas para intervirem nos processos ensino-aprendizagem e eram constituídas por psicólogo, pedagogo e orientador educacional (Marinho-Araujo, Neves, Penna-Moreira \& Barbosa, 2011; Neves, 2001).

Em 2006, uma nova OP foi publicada, ficando vigente até o ano de 2010, quando a atual Orientação Pedagógica do Serviço Especializado de Apoio à Aprendizagem foi consolidada, após construção coletiva dos profissionais das EEAA e com a supervisão e assessoria técnica das Professoras Doutoras Claisy Maria Marinho-Araujo e Marisa Maria Brito da Justa Neves, do Laboratório de Psicologia Escolar do Instituto de Psicologia da UnB. Um pouco antes, em dezembro de 2008, o serviço foi regulamentado pela Portaria $n^{\circ}$ 254/08, que estabeleceu a atuação das EEAA voltada ao assessoramento à prática pedagógica e ao acompanhamento do processo de ensino-aprendizagem em suas perspectivas institucional, interventiva e preventiva.

Em resumo, as principais informações históricas relacionadas à participação do psicólogo escolar na SEDF podem ser vistas na Linha Histórica (Figura 1): 


\section{LINHA HISTÓRICA} PSICOLOGIA ESCOLAR

NA SEDF

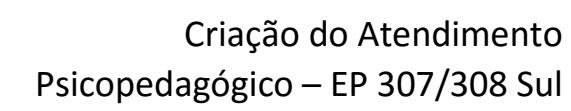

Criação da 1a Equipe de Diagnóstico e Avaliação Psicopedagógica do Ensino Especial - CEE 01 Brasília.

Publicação das Orientações

Pedagógicas (OP) 20 e 22

Criação do Projeto Permanente de Extensão Integração Universidade/Psicologia Escolar

Formação do serviço de apoio multidisciplinar denominado Equipes de Atendimento/Apoio à Aprendizagem - EAAA

Publicação da Portaria 254/2008 e criação da Comissão Pró-EEAA para elaboração da OP

Publicação da atual OP do Serviço Especializado de Apoio à Aprendizagem - SEAA

Concurso público para Analista em Gestão Educacional - Psicólogo

Lotação de um psicólogo escolar na Escola de Aperfeiçoamento dos Profissionais da Educação - EAPE

\section{1}

\section{7}

\section{4}

Transferência para o Centro de Orientação Médico Psicopedagógico - COMPP

Instituição do Atendimento

Psicopedagógico para todo o sistema público do DF

\section{2 \\ 1994 \\ Publicação da segunda edição das OP \\ 2003 \\ Fusão das Equipes de Diagnóstico/Avaliação Psicopedagógica do Ensino Especial e Equipes de Atendimento Psicopedagógico}

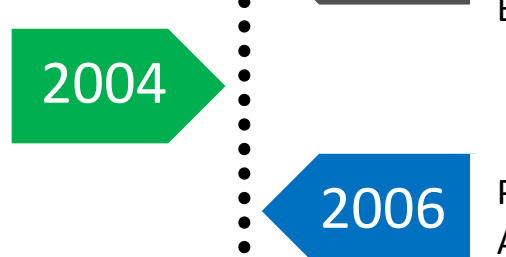

\section{8}

Elaboração da OP do Serviço Especializado de Apoio à Aprendizagem

Formação continuada em parceria com a UnB para os 430 profissionais das Equipes Especializadas de Apoio à Aprendizagem

2013 Publicação da Portaria 30/2013 - Trata do SEAA, Sala de Recursos e Itinerância

\section{4}

Formação continuada para o SEAA pela EAPE, de forma integrada com a SUBEB e o Laboratório de Psicologia Escolar da UnB, atendendo 450 profissionais

Figura 1. Linha histórica da Psicologia Escolar na SEDF.

Fonte: Elaboração do autor. 


\section{A Psicologia Escolar na SEDF nos Dias de Hoje}

No atual quadro funcional da SEDF, a Psicologia Escolar integra, com sua maioria de profissionais, um serviço de apoio técnico e educacional multidisciplinar denominado Equipes Especializadas de Apoio à Aprendizagem (EEAA), da qual faz parte, também, o profissional formado em Pedagogia. A regulamentação desse serviço ocorreu por meio da Portaria ${ }^{\circ}{ }^{254}$, de 12 de dezembro de 2008 (GDF, 2008) e permitiu o desenvolvimento de ações que fortaleceram o trabalho dessas equipes, como a realização de novos concursos públicos e a ampliação do número de profissionais nas unidades escolares. É possível encontrar psicólogos atuando em outros serviços da SEDF, tais como: Sala de Recursos Multifuncionais, que prestam atendimento a estudantes com necessidades educacionais especiais (altas habilidades/superdotação e deficiências/transtornos globais do desenvolvimento) (Brasil, 2012); Sala de Apoio à Aprendizagem, na qual são atendidos os alunos diagnosticados com transtornos funcionais; EAPE (Escola de Aperfeiçoamento dos Profissionais da Educação); ou em funções de gerência e coordenação administrativas.

A estrutura organizacional da Secretaria de Educação relacionada às Equipes Especializadas de Apoio à Aprendizagem está dividida em três níveis de atuação: (a) Central, responsável pela coordenação geral das ações desenvolvidas em toda a rede pública de ensino, cuja execução pertence a Gerência de Orientação Educacional e Serviço Especializado de Apoio à Aprendizagem, que está subordinada à Subsecretaria de Educação Básica; (b) Intermediário, que se organiza nas 14 Coordenações Regionais de Ensino, com a designação de um(a) coordenador(a) responsável por planejar, acompanhar e supervisionar as atividades dos profissionais que atuam no Serviço Especializado de Apoio à Aprendizagem; (c) Local, sediada nas unidades escolares, onde são desenvolvidas as ações dos psicólogos escolares e pedagogos vinculados às EEAA.

Dentre as ações realizadas em nível intermediário, os psicólogos escolares participam da coordenação pedagógica nas CREs, sob a supervisão da Gerência Regional de Educação Básica ${ }^{9}$. A coordenação pedagógica consiste em um espaço de reunião dos profissionais da EEAA, que acontece às sextas-feiras no turno matutino. Nesses encontros, os psicólogos e pedagogos realizam estudos de casos, discutem temas associados à prática profissional, organizam estratégias de intervenções individuais e coletivas para as demandas do serviço, desenvolvem a formação continuada por meio de estudos, de debates e reflexões teórico-metodológicas, além de executarem atividades relacionadas a cada Coordenação Regional de Ensino.

A partir da reformulação da Orientação Pedagógica, publicada em 2010, as Equipes Especializadas de Apoio à Aprendizagem ficaram caracterizadas como um serviço de apoio técnicopedagógico, de caráter multidisciplinar, prestado por profissionais com formação e devidamente habilitados em Pedagogia ou Psicologia. As EEAA atuam, principalmente, nas instituições educacionais

\footnotetext{
${ }^{9}$ A Gerência Regional de Educação Básica (GREB) administra, na Coordenação Regional de Ensino (CRE), as ações pedagógicas relacionadas ao ensino fundamental, em articulação com as unidades escolares. Supervisiona e assessora o trabalho desenvolvimento pelas EEAA por meio do coordenador intermediário do serviço.
} 
do sistema público que ofertam a Educação Infantil, Ensino Fundamental (anos iniciais e finais) e nos Centros de Ensino Especial (GDF, 2010). Entretanto, já existem Equipes atuando no Ensino Médio e na Educação de Jovens e Adultos (EJA).

Os psicólogos escolares que compõem as EEAA, apesar de possuírem formação em Psicologia, podem ocupar três cargos diferentes, a saber: (a) professor de Psicologia, (b) professor de Atividades Pedagogia (geralmente aqueles que fizeram posterior formação em Psicologia), e (c) Analista em Gestão Educacional - Psicólogo. Esse último é o cargo vigente na SEDF, após a reorganização da carreira funcional, e para o qual estão sendo formulados os concursos públicos desde o ano de 2010.

Atualmente, há 212 psicólogos escolares atuando nas EEAA, conforme tabela abaixo, distribuídos por Coordenação Regional de Ensino:

Tabela 11

Quantitativo de psicólogos escolares por Coordenação Regional de Ensino

\begin{tabular}{c|cc}
\hline Coordenação Regional de Ensino (CRE) & $\begin{array}{c}\mathrm{N}^{\mathbf{o}} \text { de Psicólogos(as) } \\
\text { Escolares }\end{array}$ & N $^{\mathbf{o}}$ de escolas por CRE ${ }^{10}$ \\
\hline Brazlândia & 9 & 30 \\
Ceilândia & 29 & 95 \\
Gama & 16 & 49 \\
Guará & 12 & 26 \\
Núcleo Bandeirante & 12 & 32 \\
Paranoá & 25 & 32 \\
Planaltina & 10 & 65 \\
Plano Piloto/Cruzeiro & 28 & 103 \\
Recanto das Emas & 13 & 26 \\
Samambaia & 10 & 40 \\
Santa Maria & 7 & 29 \\
São Sebastião & 7 & 23 \\
Sobradinho & 14 & 46 \\
Taguatinga & 20 & 62 \\
\hline Total & $\mathbf{2 1 2}$ & $\mathbf{6 5 8}$ \\
\hline
\end{tabular}

Nota: Dados retirados de SUBEB/GDF (2015b) e Censo Escolar/GDF (2015a).

\footnotetext{
${ }^{10}$ Estão incluídas na CRE Plano Piloto/Cruzeiro o PROEM - Escola Parque da Cidade, Escolas de Meninos e Meninas do Parque; Escola da Natureza e CIEF - Centro Integrado de Educação Física. Nas demais CREs estão incluídas as Instituições Educacionais vinculadas a cada cidade: as Escolas Parque, Centros Interescolares de Línguas; CEP - Escola de Música de Brasília; CEP - Escola Técnica de Saúde de Planaltina; CEP - Escola Técnica de Ceilândia e CEP - Escola Técnica de Brasília.
} 
Na Tabela 11, verifica-se uma grande heterogeneidade na distribuição dos psicólogos por CRE, explicada, em parte, pelo número diferente de escolas existentes em cada cidade. Observa-se, ainda, uma grande distância entre o número de psicólogos escolares e a quantidade de escolas do DF, seja por CRE ou em sua totalidade, ao se tomar por referência a expectativa de se ter um profissional por unidade escolar.

A Portaria n 30 de 29 de janeiro de 2013 (GDF, 2013), previu que todas as unidades escolares que oferecem as etapas e modalidades previstas para a atuação do psicólogo, contarão com a atuação itinerante do psicólogo escolar, na proporção máxima de 1500 estudantes por psicólogo, até que se amplie o quantitativo de profissionais na rede pública do DF. Isso implica dizer que ainda há uma variabilidade do número de escolas acompanhadas por cada psicólogo escolar no DF, tendo em vista o limite de alunos que a legislação determina.

Jimerson, Stewart, Skokut, Cardenas e Malone (2009), ao analisarem a relação da quantidade psicólogo-estudante, investigaram quais países no mundo incluíam, em suas leis e orientações, informações referentes a essa questão. Os autores citam os Estados Unidos, especificamente a National Association of School Psychologists (NASP), que recomenda o número máximo de 1000 alunos para cada psicólogo escolar, com a previsão de ampliação do atendimento para um grupo de 1506 estudantes, caso fossem contabilizadas as crianças em idade pré-escolar. A proporção aproximada de 1 psicólogo para 2000 alunos é encontrada em países como Austrália, Canadá, Dinamarca, Estônia, Israel, Lituânia, Escócia, Espanha, Suíça, Turquia, Austrália e nos Países Baixos.

Isso demonstra que o Distrito Federal, em termos de políticas públicas, aproxima-se aos países citados, quando comparada a proporção de psicólogos escolares para um número máximo de alunos atendidos. Pode-se dizer, inclusive, que a legislação do DF avança nessa questão, pois na rede pública há psicólogos que atendem um número inferior ao definido na Portaria, como no caso dos profissionais que atuam nos Centros de Ensino Especial e que são exclusivos dessas unidades escolares, independentemente da quantidade de alunos que acompanham.

\section{Participantes}

Os critérios de inclusão da pesquisa previram a escolha de 02 (dois) psicólogos escolares em cada Coordenação Regional de Ensino, sendo, preferencialmente, um psicólogo da carreira Analista em Gestão Educacional (até 5 anos de ingresso na SEDF) e um psicólogo com mais de 5 anos de ingresso, ocupante dos cargos de Professor em Psicologia e/ou Professor de Atividades com formação em Psicologia. Esses critérios tiveram como objetivo possibilitar o estudo das percepções, conhecimentos e vivências dos psicólogos, tanto do ponto de vista daqueles que possuem menos tempo de prática profissional nas EEAA, quanto daqueles que, por possuírem mais tempo na função, vivenciaram outras ações e atividades no serviço.

Por ser uma pesquisa na qual a participação era voluntária, após a realização do convite nas Coordenações Regionais de Ensino, não houve psicólogos participantes da cidade Recanto das Emas. 
Nas cidades de Planaltina e Núcleo Bandeirante, apenas um psicólogo de cada colaborou com a pesquisa. Em função disso, foi realizado o convite para mais uma psicóloga do Gama, o que fez com que essa cidade contabilizasse três participantes na pesquisa.

Ao todo, aceitaram colaborar com esse estudo e participar da pesquisa 25 psicólogos escolares que atuavam nas Equipes Especializadas de Apoio à Aprendizagem (EEAA) em 13 cidades ${ }^{11}$. A média de idade dos participantes foi de 35 anos, variando entre 27 a 57 anos de idade; a grande maioria do grupo de psicólogos é do sexo feminino, sendo apenas um participante do sexo masculino. O tempo médio de atuação nas EEAA é de 5 anos e 7 meses, com intervalo variando de 1 (um) mês de atuação no serviço a 22 (vinte e dois) anos, à época da recolha das informações da pesquisa.

Dentro do grupo de psicólogos que participaram da pesquisa, três atuam em Centros de Ensino Especial (CEE), três em equipes das séries finais/ensino médio e os demais participantes trabalham em escolas de séries iniciais do ensino fundamental. Essas informações foram recolhidas por meio de perguntas constantes no roteiro de entrevista semiestruturada (Anexo 3). Com exceção dos psicólogos escolares que atuam cada um em um CEE e de uma psicóloga que atende a uma escola de ensino médio, os demais participantes acompanham duas ou mais escolas em sua rotina profissional.

Em relação à formação inicial dos participantes, 19 dos 25 psicólogos concluíram a graduação em Instituições de Ensino Superior (IES) do DF, sendo 11 no UniCEUB, 5 na UnB e 3 na UNIP, UCB e UDF. Os demais participantes realizaram a formação inicial em outros estados, a saber: Bahia, Piauí, Paraíba, Minas Gerais e Goiás. Das 11 IES citadas pelos participantes, 6 são particulares e 5 são públicas, sendo a Universidade de Brasília a única do DF nesse critério. Os participantes concluíram o curso de Psicologia, em média, há 12 anos, sendo que a psicóloga com menor tempo de término da graduação é de 4 anos, enquanto que a de maior tempo relatou ter finalizado o curso há 34 anos.

O quadro abaixo descreve as informações de caracterização dos participantes, que serão identificados pela letra $\mathrm{P}$, acompanhada de um número para distingui-los:

\footnotetext{
11 Brazlândia, Ceilândia, Gama, Guará, Santa Maria, Samambaia, São Sebastião, Sobradinho, Taguatinga, Planaltina, Plano Piloto, Paranoá, e Núcleo Bandeirante.
} 
Tabela 12

Caracterização dos participantes

\begin{tabular}{|c|c|c|c|c|c|c|}
\hline Participante & Sexo & Idade & $\begin{array}{l}\text { CRE de } \\
\text { atuação }\end{array}$ & $\begin{array}{l}\text { Tempo de } \\
\text { atuação nas } \\
\text { EEAA }\end{array}$ & $\begin{array}{c}\text { Ano de } \\
\text { conclusão da } \\
\text { graduação }\end{array}$ & $\begin{array}{l}\text { Instituição } \\
\text { formadora }\end{array}$ \\
\hline $\mathrm{P} 1$ & $\mathrm{~F}$ & 40 & Gama & 12 anos & 1996 & UniCEUB \\
\hline $\mathrm{P} 2$ & $\mathrm{~F}$ & 39 & Gama & 2 anos & 2007 & UNIP \\
\hline $\mathrm{P} 3$ & $\mathrm{~F}$ & 31 & Taguatinga & 1 ano e 3 meses & 2005 & UniCEUB \\
\hline $\mathrm{P} 4$ & $\mathrm{~F}$ & 39 & Gama & 16 anos & 1997 & UniCEUB \\
\hline P5 & $\mathrm{F}$ & 31 & Ceilândia & 2 anos & 2006 & UniCEUB \\
\hline P6 & $\mathrm{F}$ & 27 & Guará & 8 meses & 2010 & UniCEUB \\
\hline $\mathrm{P} 7$ & $\mathrm{~F}$ & 30 & Santa Maria & 2 anos & 2007 & UCB \\
\hline P8 & $\mathrm{F}$ & 30 & Samambaia & 1 mês & 2007 & UFBA \\
\hline P9 & $\mathrm{F}$ & 29 & Guará & 2 anos e 1 mês & 2008 & UESPI \\
\hline P10 & $\mathrm{F}$ & 47 & Samambaia & 20 anos & 1990 & UniCEUB \\
\hline P11 & $\mathrm{F}$ & 30 & Paranoá & 9 meses & 1997 & UniCEUB \\
\hline $\mathrm{P} 12$ & $\mathrm{~F}$ & 38 & Taguatinga & 1 ano e 6 meses & 2006 & UnB \\
\hline $\mathrm{P} 13$ & $\mathrm{~F}$ & 43 & Ceilândia & 16 anos & 1997 & UnB \\
\hline P14 & $\mathrm{F}$ & 27 & Brazlândia & 3 anos & 2010 & UnB \\
\hline $\mathrm{P} 15$ & $\mathrm{~F}$ & 49 & Brazlândia & 15 anos & 1999 & UFPB \\
\hline P16 & $\mathrm{F}$ & 37 & Paranoá & 2 anos e 2 meses & 2000 & UniCEUB \\
\hline P17 & $\mathrm{F}$ & 26 & Sobradinho & 1 anos e 3 meses & 2012 & UniCEUB \\
\hline P18 & $\mathrm{F}$ & 49 & Plano Piloto & 1 ano & 2010 & IESB \\
\hline P19 & $\mathrm{F}$ & 57 & Plano Piloto & 14 anos & 1982 & UniCEUB \\
\hline $\mathrm{P} 20$ & $\mathrm{~F}$ & 30 & Planaltina & 1 ano & 2009 & UFMG \\
\hline $\mathrm{P} 21$ & $\mathrm{~F}$ & 28 & São Sebastião & $\begin{array}{c}2 \text { anos e } 10 \\
\text { meses }\end{array}$ & 2010 & UnB \\
\hline $\mathrm{P} 22$ & $\mathrm{~F}$ & 47 & Sobradinho & 22 anos & 1990 & UniCEUB \\
\hline $\mathrm{P} 23$ & $\mathrm{~F}$ & 30 & São Sebastião & $\begin{array}{c}2 \text { anos e } 10 \\
\text { meses }\end{array}$ & 2008 & UnB \\
\hline $\mathrm{P} 24$ & $\mathrm{~F}$ & 28 & Santa Maria & 1 ano e 5 meses & 2008 & UNIRV \\
\hline $\mathrm{P} 25$ & M & 27 & $\begin{array}{c}\text { Núcleo } \\
\text { Bandeirante }\end{array}$ & 9 meses & 2010 & UNIPAM \\
\hline
\end{tabular}




\section{Procedimentos de Construção e Recolha das Informações}

Esta pesquisa de mestrado foi aprovada pelo Comitê de Ética do Instituto de Ciências Humanas da Universidade de Brasília, de acordo com a orientação da Resolução 466/12 que rege as pesquisas em Psicologia. Após a aprovação do Comitê de Ética (Parecer 995.713, Anexo 1), foram agendadas as entrevistas com os(a)s psicólogos(as) por telefone e/ou e-mail e realizadas, preferencialmente, nos locais de trabalho dos participantes. Após apresentação e leitura do Termo de Consentimento Livre e Esclarecido - TCLE (Anexo 2), cada psicólogo assinou o documento, concordando com sua participação na pesquisa.

Nos próximos tópicos dessa seção são detalhados os procedimentos e o instrumento utilizado na pesquisa, relacionando-os aos pressupostos teórico-metodológicos, aos objetivos e ao contexto de realização das entrevistas.

Entrevistas com os psicólogos escolares. $\mathrm{Na}$ pesquisa qualitativa as entrevistas são fundamentais para a compreensão do contexto do participante, apreendendo as práticas, crenças, valores e sistemas classificatórios de universos sociais específicos, mais ou menos bem delimitados, em que os conflitos e contradições não estejam claramente apresentados ao pesquisador (Duarte, 2004). As entrevistas permitem ao pesquisador fazer uma espécie de imersão na realidade investigada, apreendendo indícios dos modos como cada um dos sujeitos percebe e significa sua realidade, possibilitando a compreensão das relações que se estabelecem no interior de determinado grupo.

A entrevista é marcada pela dimensão social e não pode reduzir-se a uma troca de perguntas e respostas, sendo compreendida como uma produção cultural. Segundo Freitas (2002), "na entrevista é o sujeito que se expressa, mas sua voz carrega o tom de outras vozes, refletindo a realidade de seu grupo, gênero, etnia, classe, momento histórico e social" (p. 9). Segundo Molon (2008), ao entrevistar, busca-se um envolvimento e comprometimento com a experiência do sujeito nas suas relações intersubjetivas e nas suas práticas sociais.

As entrevistas individuais, nesta pesquisa, investigaram algumas características relacionadas aos indicadores do perfil profissional: concepções, conhecimentos, competências, saberes e habilidades, percepções, opiniões, hábitos, crenças, valores, linguagens e códigos predominantes, posturas e opiniões (Marinho-Araujo, 2009). As entrevistas foram realizadas com a utilização de roteiro semiestruturado e gravação do áudio, e foram construídas de modo a permitir o acréscimo de novas questões durante o procedimento, dando maior fluidez ao diálogo com o participante. A elaboração do roteiro da entrevista foi orientada pelas grandes temáticas que subsidiam a dissertação: formação, atuação e o perfil profissional, sendo definidos os seguintes tópicos: (a) caracterização (b) formação inicial, (c) formação continuada, (d) atuação profissional e (e) características do perfil do Psicólogo Escolar das EEAA.

Para a realização das entrevistas foram estabelecidos, inicialmente, contatos por e-mail com os Coordenadores Intermediários das EEAA, solicitando a ampla divulgação do convite para os psicólogos escolares por meio de correio eletrônico e nas coordenações coletivas ocorridas em cada cidade. Foi 
efetuado mais um contato com os participantes, via e-mail e/ou por telefone, a partir de uma lista de psicólogos da SEDF que integravam as reuniões de formação na UnB. Outro procedimento utilizado foi a técnica de "bola-de-neve", pela qual foi solicitado aos participantes que indicassem outros profissionais que atenderiam aos critérios de inclusão da pesquisa. Foi realizada uma única entrevista com cada participante, com duração média de cinquenta minutos.

As entrevistas ocorreram nas escolas nas quais os psicólogos escolares trabalhavam, exceção feita a três participantes que solicitaram o agendamento em outros locais ${ }^{12}$, visando facilitar seus deslocamentos. Quando feitas nas escolas dos participantes, as entrevistas ocorreram na sala da Equipe Especializada de Apoio à Aprendizagem que, em algumas ocasiões, contou com a presença da pedagoga que compõe a EEAA, porém, sem que esta profissional participasse da entrevista. Essa situação ocorreu por duas vezes e justificou-se pelo fato de a pedagoga, que compartilha a mesma sala da instituição escolar com o psicólogo, necessitar utilizar algum material que estava no ambiente.

Ocorreram situações em que a entrevista foi interrompida para que a participante atendesse a alguma demanda da escola; entretanto, foram pausas rápidas que não atrapalharam ou suspenderam a continuação do procedimento de pesquisa. Em algumas escolas, em função da entrevista ter sido agendada próxima ao horário do intervalo, foi possível ouvir um som ambiente mais alto (música, crianças correndo e brincando, por exemplo), mas nada que influenciasse a qualidade da recolha das informações.

Procedimento de Análise das Informações. Essa seção dedica-se à apresentação do procedimento da análise das informações construídas no procedimento de entrevistas, realizadas com os(as) psicólogos(as) escolares das Equipes Especializadas de Apoio à Aprendizagem.

Os instrumentos na pesquisa qualitativa são compreendidos como um meio para provocar a expressão do sujeito, "estimulando a produção de tecidos de informação, e não de respostas pontuais" (González Rey, 2005, p. 43). Representam uma fonte de informações sobre o pesquisado, que toma forma nos indicadores a partir das informações produzidas pelo sujeito estudado (González Rey, 1999).

A análise das entrevistas individuais permitiu o desenvolvimento da interpretação e da construção de indicadores a partir das informações dos participantes, bem como o exercício de uma postura reflexiva para lidar com os conteúdos que emergiram, à luz dos objetivos propostos nesta pesquisa. Para González Rey (2002b)

a produção de indicadores e a de categorias são processos inter-relacionados, pois, se as ideias associadas com o desenvolvimento dos indicadores não se expressam em categorias, o processo gerador de teoria sobre o qual repousa o curso da pesquisa corre o risco de interromper-se e levar ao círculo vicioso de reiteração do conhecido. (p. 119)

A construção dos indicadores na pesquisa foi possível em função dos sentidos e significados expressos pelos participantes, que permitiram a construção das categorias de análise a partir da

\footnotetext{
${ }^{12}$ As três entrevistas foram realizadas na UnB, na EAPE e no consultório particular de uma das participantes.
} 
interpretação do pesquisador. Foram verificadas as repetições, concordâncias, semelhanças, contradições e outros elementos das falas dos entrevistados para a organização e categorização dos indicadores de perfil do psicólogo escolar das EEAA.

As questões utilizadas nas entrevistas serviram de base para a formulação das categorias de análise da pesquisa, que se fundamentaram no trabalho de Marinho-Araujo (2003):

- Competências teóricas, científicas e metodológicas - conhecimento, aprofundamento e domínio das bases teórico-conceituais e metodológicas da Psicologia e da Psicologia Escolar, em particular, e a capacidade de utilizá-los em diferentes contextos.

- Competências práticas e técnicas - conhecimentos metodológicos e operacionais, articulados aos conhecimentos teóricos, que possibilitam a utilização de técnicas, procedimentos, instrumentos e estratégias da ciência psicológica na atuação profissional.

- Competências pessoais, interpessoais e sociais - características, conhecimentos, crenças e percepções do sujeito acerca das próprias concepções, que expressam-se na relação com o outro. Facilidade para a construção de espaços de interlocução e promoção de ações coletivas. Disponibilidade em avaliar e rever a própria atuação, em um processo contínuo de aperfeiçoamento profissional.

- Competências éticas e estéticas - sensibilidade em considerar a singularidade de cada situação, levantando questionamentos reflexivos e críticos sobre decisões, posturas e ações. Compromisso político com a profissão e com a atuação profissional. Habilidade para potencializar a imaginação, perspicácia, percepções e sentidos como processos psicológicos favoráveis à prática profissional. (p. 309).

A entrevista semiestruturada continha as seguintes questões acerca das competências e perfil profissional do psicólogo escolar:

- Quais os conhecimentos teóricos, científicos e metodológicos necessários à atuação nas EEAA?

- Quais os conhecimentos práticos e técnicos necessários à atuação nas EEAA?

- Quais as características pessoais, interpessoais e sociais desejáveis para a atuação nas EEAA?

- Que competências éticas e estéticas e outras são desejáveis à atuação nas EEAA?

O material produzido nas entrevistas foi interpretado e analisado à luz dos referenciais teóricos da Psicologia Histórico-Cultural e da Psicologia Escolar (como campo de produção teórica), com o objetivo de apontar indicadores do perfil profissional do psicólogo escolar das EEAA. 


\section{Capítulo 5}

\section{Discussão e Resultados}

A finalidade deste capítulo é apresentar as análises das informações recolhidas e construídas ao longo desta pesquisa de mestrado. Evidenciam-se as contribuições dos psicólogos escolares participantes e discutem-se, à luz da Psicologia Histórico-cultural e da produção teórica da Psicologia Escolar, os indicadores de perfil profissional apontados por esse estudo. As respostas dos participantes à entrevista foram organizadas tendo como base os estudos de Marinho-Araujo (2003), categorizadas em indicadores de competências: teóricas, científicas e metodológicas; técnicas e práticas; sociais, pessoais e interpessoais; éticas e estéticas. As definições desses indicadores foram descritas no capítulo em que se apresentaram os pressupostos metodológicos adotados e serão retomadas neste capítulo de análise.

O objetivo da categorização das respostas dos participantes foi o de mapear as características para a construção do perfil do psicólogo escolar das Equipes Especializadas de Apoio à Aprendizagem da SEDF, considerando percepções, conhecimentos e vivências dos entrevistados acerca da atuação profissional e das competências exigidas para o trabalho desenvolvido pelo psicólogo. Buscou-se organizar as falas dos entrevistados a partir do agrupamento de temas similares presentes nas respostas, associando-os às categorias já previamente explicitadas pelas questões do roteiro da entrevista individual. Um mesmo participante pode ter citado mais de uma característica de perfil para os indicadores retratados nas categorias apresentadas.

A seguir, serão relacionadas tabelas com a definição das competências e a categorização dos indicadores das referidas competências, seguidos do número de psicólogos escolares que os citaram durante as entrevistas. Os indicadores serão analisados e discutidos após cada tabela.

\section{Tabela 13}

\section{Indicadores de Competências Teóricas, Científicas e Metodológicas}

Conhecimento, aprofundamento e domínio das bases teórico-conceituais e metodológicas da Psicologia e da Psicologia Escolar, em particular, e a capacidade de utilizá-los no contexto escolar.
$\mathrm{N}^{\mathrm{o}}$ de psicólogos que citaram o indicador $(n=25)$

Domínio da psicologia do desenvolvimento humano

Apropriação da abordagem histórico-cultural do desenvolvimento psicológico

Compromisso com o estudo e formação continuada

Apropriação dos conhecimentos da psicologia escolar 
Domínio da psicologia da aprendizagem

Serão destacados da Tabela 3 para análise, os principais indicadores, apontados pelo maior número de entrevistados, para caracterizar as competências teóricas, científicas e metodológicas que podem compor o perfil profissional do psicólogo escolar nas EEAA da SEDF: domínio da psicologia do desenvolvimento humano; apropriação da abordagem histórico-cultural do desenvolvimento psicológico; compromisso com o estudo e formação continuada.

$\mathrm{O}$ indicador domínio da psicologia do desenvolvimento humano foi sinalizado por 18 participantes como uma competência teórica/científica necessária à prática do psicólogo escolar da EEAA. Os relatos dos entrevistados, citados a seguir, demonstram a importância que os psicólogos atribuem à aquisição desse tipo de conhecimento em nível teórico: "Desenvolvimento humano é básico, tinha que ter muita ênfase no desenvolvimento humano pra começar a trabalhar" (P3); "É importantíssimo saber sobre a questão do desenvolvimento humano, não tem como você querer atender uma criança sem estar sabendo do desenvolvimento" (P4); "Acho importante uma bagagem teórica grande em termos de desenvolvimento humano, tanto infantil quanto adulto" (P16); "Precisa ter um conhecimento de desenvolvimento humano" (P25).

Observa-se, na opinião de P16, um olhar diferenciado para o desenvolvimento humano, pois indica uma preocupação em conhecer, também, os processos que envolvem o ser humano adulto. A ideia de se pensar o desenvolvimento humano adulto pode indicar, dentro do perfil do psicólogo escolar, uma mudança nas práticas diárias na escola, considerando os diversos atores educacionais como sujeitos de desenvolvimento e não apenas as crianças ou estudantes. Isso permite uma ampliação do trabalho do psicólogo, para além do atendimento ao aluno, envolvendo todos os profissionais da escola como sujeitos de potencialidades. P3 destaca a necessidade dessa temática, dada a sua importância para a atuação do psicólogo, sendo uma prioridade estudá-la antes da entrada no campo de trabalho, ou seja, é uma fundamentação que deveria estar presente já na formação inicial do psicólogo escolar. $\mathrm{O}$ indicador de perfil domínio da psicologia do desenvolvimento humano, ao ser apontado por grande parte dos psicólogos entrevistados, pode sugerir um reconhecimento da especificidade teórica do psicólogo escolar com relação ao domínio de teorias que embasem sua atuação, especialmente as que se referem ao desenvolvimento psicológico humano.

Em consonância com os relatos dos psicólogos, a OP/2010 (GDF, 2010) destaca, como elemento do perfil desse profissional, "o conhecimento acerca dos processos de desenvolvimento e de aprendizagem, das características e fatores determinantes do desenvolvimento humano na infância, na adolescência e na vida adulta" (p. 83). Bisinoto, Marinho-Araujo e Almeida (2011) abordam a 
importância das práticas dos psicólogos estarem ancoradas em aprofundamentos teórico-conceituais, consolidando uma atuação voltada à promoção do desenvolvimento humano em sua diversidade.

Em consonância com a importância dada aos conhecimentos sobre a psicologia do desenvolvimento, igualmente um expressivo número de profissionais relata o indicador apropriação da abordagem histórico-cultural do desenvolvimento psicológico, que aparece nas falas como uma especificidade das teorias do desenvolvimento humano e acreditam ser necessária ao perfil do psicólogo escolar para a atuação na EEAA. A psicóloga P7 faz menção a esse indicador, ao dizer que

Acredito que a questão do desenvolvimento é importantíssima, a questão da aprendizagem e tudo que está influenciando ali, o que traz a teoria do Vygotsky e 'companhia', que não é só a questão biológica ou familiar, que é tudo junto. A gente tem que aprimorar esses estudos nessa perspectiva (...) acho que esses saberes são os principais, a questão do desenvolvimento, da aprendizagem e da teoria histórico-cultural (P7).

Para a psicóloga P10, "Em termos de teoria, a que mais embasa o nosso trabalho é a teoria de Vygotsky. Eu acho que é a teoria que mais tem a ver, que tem um embasamento teórico que sustenta nosso trabalho" (P10). Há um processo reflexivo das participantes acerca de qual teoria psicológica, entre as bases do desenvolvimento humano, melhor embasa sua prática na escola, identificando na abordagem histórico-cultural o corpo teórico-conceitual que atende à especificidade de sua atuação. A participante P7 indica a necessidade de aprofundar estudos sobre essa abordagem, correlacionando a esses conhecimentos a compreensão da aprendizagem humana e dos fatores que a influenciam, além dos aspectos biológicos e familiares, somente.

A OP/2010 (GDF, 2010) sustenta, como pressuposto para a concepção de desenvolvimento, a ideia do "ser humano como um ser ativo, que age sobre o mundo e que, por meio das relações sociais, transforma suas ações internamente.” (GDF, 2010, p. 56). Nesse documento orientador, a perspectiva histórico-cultural é apresentada como fundamento teórico-metodológico para a consecução do trabalho desenvolvido pelo psicólogo escolar, assumindo um ponto de vista epistemológico acerca do sujeito, da escola e do mundo. Igualmente, há na literatura referências às contribuições da psicologia históricocultural nas práticas educativas, direcionando o trabalho do psicólogo escolar a partir de questões que remetem à compreensão das relações e processos de desenvolvimento em uma dimensão dialética e histórica (Barroco, 2011; Facci \& Souza, 2011; Marinho-Araujo, 2014a; Marinho-Araujo \& Almeida, 2005; Souza, Petroni, Dugnani, Barbosa \& Andrada, 2014).

Ainda em relação ao domínio de teorias psicológicas que embasam a prática profissional, a OP/2010 (GDF, 2010), ao referir-se ao perfil profissional do psicólogo, prevê que este desenvolva maior clareza acerca da relação entre as concepções teóricas sobre o conhecimento psicológico e o trabalho a ser desenvolvido nas escolas, além da busca por fundamentação para o planejamento de estratégias interdisciplinares de ação que integrem e legitimem a intervenção psicológica. A diretriz estabelece a necessidade de o psicólogo escolar ter o "domínio de teorias, de conceitos e de metodologias da 
Psicologia para intervenções psicológicas de caráter preventivo, individual ou coletivo, em contextos educativos" (GDF, 2010, p. 86).

O indicador compromisso com o estudo e formação continuada foi o terceiro mais citado pelos participantes da pesquisa, que destacaram a necessidade de buscar, continuamente, saberes relacionados ao seu campo de conhecimento e prática profissional, como parte do desenvolvimento do perfil do psicólogo escolar da EEAA. A participante P21 enfatiza que

O mais importante pra mim, pelo menos antes de qualquer coisa, é ter disponibilidade pra estudar, pra pesquisar, porque você chega na escola e não tem uma coisa muito pronta, até tem no papel, o que é esperado, mas tem coisas que você precisa desenvolver (P21).

Para a psicóloga P22, "O embasamento teórico é super importante, mas saber colocar em prática, também é. Então, nós estudamos, nós lemos, nós entendemos e nós sugerimos intervenções" (P22). A partir das considerações das participantes P21 e P22, torna-se visível a importância e a necessidade que o estudo e a formação continuada têm na composição do perfil do psicólogo escolar, além da vinculação do aspecto teórico com a prática desenvolvida nas unidades escolares. Mesmo considerando as orientações, manuais ou outros tipos de diretrizes que guiem a atuação profissional na SEDF, a busca por novos conhecimentos e a ressignificação dos saberes aprendidos deveriam ser competências a serem desenvolvidas pelo psicólogo, pois são vastas as fontes de estudo relacionadas ao trabalho e aos temas abordados por esse profissional.

A participante P2 confirma a necessidade do desenvolvimento dessa competência ao afirmar que "Tem que estar sempre estudando, sempre se atualizando, com cursos, com livros, com palestras, porque é muito dinâmico esse mundo escolar, tanto é que cada caso é um caso. Em Psicologia, não dá pra generalizar" (P2). Neste caso, a entrevistada destaca a dinamicidade do contexto escolar e que a busca pelo estudo e pela formação continuada, enquanto competência teórica do psicólogo, possibilita a atualização e a contextualização do conhecimento psicológico às demandas educacionais, evitandose, assim, generalizações e atuações sem fundamentos.

A autonomia na busca de conhecimentos e a disponibilidade para revisitar as próprias concepções devem pautar a prática do psicólogo, permitindo que se revejam as crenças e pontos de vista a partir de novas atualizações e orientações (Marinho-Araujo, 2003, p. 122). Na OP/2010 da EEAA (GDF, 2010) é esperado do psicólogo escolar uma "busca constante de fundamentação e de segurança para o planejamento de estratégias interdisciplinares de comunicação e de ação que integrem e legitimem a intervenção psicológica" (GDF, 2010, p. 68). O indicador de perfil profissional compromisso com o estudo e formação continuada pressupõe que o psicólogo desenvolva, além de sua própria formação, ações individuais e coletivas na escola, mobilizando outros atores para ações formativas em contextos institucionais diferenciados.

Para Mitjáns Martínez (2007) a busca por formação continuada é um compromisso a ser assumido pelo próprio psicólogo escolar, responsabilizando-se pelo processo de aprimoramento da prática profissional, com vistas à aceitação de novos desafios. O desenvolvimento da iniciativa e 
autonomia frente a situações de conflitos, a capacidade de análise e a reelaboração e aplicação do conhecimento psicológico ao campo profissional, foram destacados por Marinho-Araujo e Neves (2007) como algumas ênfases necessárias à formação dos psicólogos; além disso, a eficaz articulação entre teoria e prática foi apontada como a principal meta para o desenvolvimento de competências profissionais.

Os psicólogos escolares que participaram dessa pesquisa reconheceram as limitações teóricas e metodológicas que caracterizam o seu campo de conhecimento e atuação e já identificaram a necessidade de buscar, por meio da formação continuada em serviço, os saberes que os auxiliem no entendimento e consecução das práticas profissionais. Essa busca exige iniciativa e autonomia frente aos desafios que o processo de formação continuada impõe ao psicólogo, sejam eles de ordem institucional ou pessoal.

A partir das considerações dos psicólogos entrevistados e de acordo com as discussões realizadas até esse momento, é possível propor uma síntese dos principais indicadores de competências teóricas, científicas e metodológicas, que podem ser úteis à formação do perfil profissional do psicólogo escolar:

- Domínio da psicologia do desenvolvimento humano - Conhecimento das teorias psicológicas relacionadas ao processo de desenvolvimento humano e sua relação com as práticas de escolarização, ensino e aprendizagem.

- Apropriação da abordagem histórico cultural do desenvolvimento psicológico - Estudo dos pressupostos teórico-metodológicos da abordagem histórico cultural do desenvolvimento e sua aplicação ao campo da Educação.

- Compromisso com o estudo e formação continuada - Desenvolvimento, com responsabilidade e compromisso, de ações regulares e permanentes de estudo e aperfeiçoamento profissional.

Tabela 14

Indicadores de Competências Técnicas e Práticas

Conhecimentos metodológicos e operacionais, articulados aos conhecimentos $\quad \mathrm{N}^{\mathrm{o}}$ de psicólogos teóricos, que possibilitam a utilização de técnicas, procedimentos, que citaram o instrumentos e estratégias da ciência psicológica na atuação profissional. indicador $(n=25)$

Desenvolvimento da escuta psicológica

Apropriação da atuação institucional e coletiva

Domínio da avaliação psicológica

Capacidade de organização 
Compreensão da intervenção junto ao professor

Sensibilidade para compreender o contexto e as práticas educacionais

Desenvolvimento de análise crítica da realidade

De acordo com a sistematização na Tabela 4, serão comentados, a seguir, os principais indicadores sinalizados pelos entrevistados para caracterizar as competências técnicas e práticas que podem compor o perfil profissional do psicólogo escolar na EEAA da SEDF: desenvolvimento da escuta psicológica; apropriação da atuação institucional e coletiva; domínio da avaliação psicológica; capacidade de organização.

$\mathrm{O}$ desenvolvimento da escuta psicológica foi o indicador de competência técnica e prática mais destacado pelos psicólogos. Dentre os 25 participantes, 19 enfatizaram esse indicador, como se evidencia no seguinte trecho:

Acho que a escuta psicológica é muito importante e é, ao mesmo tempo, algo que a gente desenvolve pouco, porque é um contexto que é tão turbulento, é tanta coisa acontecendo ao mesmo tempo, num contexto escolar, que às vezes você esquece de dar um ouvido diferenciado pra aquilo que tá acontecendo (P5).

A psicóloga P5 entende que a escuta psicológica é uma competência técnica diferenciada do perfil, ao considerar que exige do profissional uma capacidade para ouvir o que está acontecendo no contexto escolar, nem sempre visível ou claro diante das situações ou acontecimentos do cotidiano escolar. Para a psicóloga P8,

A escuta é mais do que necessária pra gente, inclusive, entender como o outro pensa. Nesse processo de escuta, penso assim, a escuta e a forma como você vai se colocar (...) pra gente poder problematizar, a gente precisa escutar, até pra encontrar a brecha do discurso do outro, pra saber onde mesmo vou trazer a problematização para desestabilizar (P8).

A competência profissional da escuta psicológica é também reconhecida como uma oportunidade para identificar as contradições, as queixas, as potencialidades e "brechas" para as intervenções do psicólogo escolar. A psicóloga P13, ao referir-se a essa competência profissional, reconhece que na escuta psicológica o profissional desenvolve "o ouvir, o entender as questões que não estão tão emergentes, tão claras, entender esse não dito... como funciona... as relações de poder" (P13). Mais uma vez, essa característica de perfil relaciona-se à capacidade de perceber e compreender o contexto relacional que envolve a atuação do psicólogo, bem como daqueles que compartilham as rotinas, atividades e situações do cotidiano escolar.

As falas e sentidos compartilhados pelas psicólogas evidenciaram que a escuta psicológica não é entendida como aquela prevista no modelo clínico, terapêutico, mas está mais voltada para uma percepção diferenciada acerca das ações institucionais e coletivas, conforme já se discute na literatura sobre a Psicologia Escolar (Andrada, 2005; Costa \& Guzzo, 2006; Marinho-Araujo \& Almeida, 2005; 
Marinho-Araujo, 2014a) e na OP/2010 (GDF, 2010) da EEAA. Esse último documento, apoiado no trabalho de Marinho-Araujo (2003), discorre acerca da "sensibilidade para integrar, nos processos relacionais, saberes e conhecimentos, ouvindo o outro, respeitando diferentes pontos de vista, abrindose para o novo, disponibilizando conquistas pessoais em prol de projetos coletivos" (p. 86). A escuta psicológica, de acordo com Marinho-Araujo (2014a), coloca o psicólogo em posição para ouvir e compreender a singularidade das demandas, assim como questioná-las e investigá-las. A autora diz que é necessário ao psicólogo escolar "ouvir, ver, sentir, viver indicadores objetivos, subjetivos, simbólicos do amálgama dialético entre o psíquico e o social." (p. 167). A participante P17 enfatiza a especificidade do processo de escuta na prática profissional, ao dizer que "A escuta é a ferramenta principal do psicólogo em qualquer ambiente" (P17). A escuta psicológica é entendida como a ação de observar a realidade escolar para

mapear espaços, tempos, fazeres, crenças, concepções e dinâmicas, desenvolver sensibilidade de escuta dos discursos institucionais e das "vozes da escola", provocar a ressignificação das demandas e criar novos espaços para interlocução e circulação de falas e discursos dos sujeitos; essas são competências necessárias à intervenção psicológica coadunada ao desenvolvimento de uma conscientização que pode provocar mudanças significativas, consistentes e duradouras na prática pedagógica. (Marinho-Araujo, 2010, p. 27).

Nessa concepção acerca da escuta psicológica, os espaços escolares para a intervenção do psicólogo podem constituir-se tanto por situações emergenciais no cotidiano escolar, quanto em atividades planejadas de forma intencional por este profissional, tais como reuniões com a equipe escolar, alunos ou familiares, estudos de casos, rodas de conversa, além de outros contextos institucionais (Carvalho \& Marinho-Araujo, 2010; Marinho-Araujo, 2014). Essa nova dimensão do olhar ou da escuta psicóloga está alicerçada em uma atuação mais voltada para o institucional e para as ações coletivas desenvolvidas pelo psicólogo escolar, individualmente ou com outros profissionais da escola.

A apropriação da atuação institucional e coletiva foi apontada por 18 participantes como um dos principais indicadores de competência técnica e prática do psicólogo da EEAA. Para a participante P15, a atuação do psicólogo faz-se ampliada dentro da escola, o que permite uma melhor inserção nos espaços e práticas educativas. Ela afirma que

A gente consegue e participa também da formação das turmas. E, então, a gente todo ano senta com a direção e monta as turmas. Como a gente conhece todos os alunos e as modalidades, a gente faz a montagem das turmas e, no decorrer do ano, se a gente percebe que uma ou outra coisa não ficou bem aceita, a gente conversa e tenta reajustar. A gente sempre senta com o professor, coordena com os professores, participa das reuniões por área, participa da coletiva... Então, assim a gente tem espaço (P15).

Esse relato corrobora a opinião de Mitjáns Martínez (2010) ao afirmar que o trabalho do psicólogo pode ser profícuo no uso de estratégias e técnicas junto às equipes de trabalho, iniciando pela 
direção e alcançando os outros atores educacionais. A autora destaca, ainda, que a atuação do psicólogo escolar, dentro de sua especificidade, se soma ao trabalho das outras equipes pedagógicas, colaborando para a consecução das metas e atividades propostas.

A psicóloga P20, ao referir-se ao indicador de perfil apropriação da atuação institucional e coletiva, relatou que "Trabalho muito com o coletivo, eu tento ampliar... a partir do caso de um aluno, vamos ver quais casos que têm na escola, como posso trabalhar preventivamente com a escola inteira" (P20). Nesse relato, percebe-se que a psicóloga desenvolveu um olhar para as ações coletivas e institucionais, reconhecendo nelas possibilidades de ampliação do seu trabalho. Na perspectiva da Psicologia Escolar contemporânea, a noção de prevenção fundamenta-se na superação de visões conservadoras e adaptacionistas da realidade escolar e na promoção de reflexões dos atores envolvidos, possibilitando transformações e saltos qualitativos no desenvolvimento de cada sujeito (MarinhoAraujo, 2014). A atuação preventiva estabelece a necessidade de se buscar ações que facilitem a construção de estratégias diversificadas para os processos de ensino e aprendizagem, além de promover a conscientização dos papéis e responsabilidades dos sujeitos envolvidos nas ações educativas (Marinho-Araujo \& Almeida, 2014). Para que essas ações sejam possíveis, na perspectiva da atuação institucional e preventiva, o psicólogo precisa participar dos espaços de interlocução dentro da instituição ou criá-los para que seja possível a circulação de conhecimentos, percepções e sentidos dos atores educacionais.

A participante P10, ao tratar da atuação institucional, destaca o papel formativo que o psicólogo assume frente a outros profissionais da escola, principalmente os professores. Essa entrevistada faz referência à cultura do sucesso que deve ser disseminada no interior das escolas, notadamente nos casos relacionados ao processo de desenvolvimento e aprendizagem do aluno. A participante afirma a necessidade de

Reunir os professores para estar discutindo realmente os casos, mas num grupo maior, porque a gente faz isso de uma maneira mais próxima, mas para que eles também possam desenvolver as competências entre eles mesmos. Eu fiz isso assim e deu certo, dentro do grupo. Partir pra uma coletiva onde cada um possa apresentar os resultados positivos em relação àquele aluno que teve dificuldade de aprendizagem porque, entre eles, vai disseminando essa cultura do sucesso (P10).

Neste trecho, evidenciam-se dois importantes elementos que transversalizam o perfil do psicólogo escolar: a mediação do psicólogo no desenvolvimento de competências de outros profissionais e a disseminação da cultura do sucesso.

A atuação do psicólogo escolar na assessoria ao trabalho docente foi destacada em trabalhos (Marinho-Araujo, 2014a; Marinho-Araujo \& Almeida, 2014), que enfatizaram a importância dos processos de mediação que acontecem nos contextos educativos, criando espaços de interlocução e de formação de outros profissionais da escola. Para Vygotsky (2007) "o uso de meios artificiais - a transição para a atividade mediada - muda, fundamentalmente, todas as operações psicológicas, assim 
como o uso de instrumentos amplia de forma ilimitada a gama de atividades em cujo interior as novas funções psicológicas podem operar" (p. 56). A partir das considerações de Vygotsky (2007), compreende-se o importante papel do psicólogo escolar como mediador do desenvolvimento de outros sujeitos, sejam crianças, jovens ou adultos, transformando, de forma intencional, as funções psicológicas e promovendo a conscientização de seus papéis na instituição escolar.

As participantes P9 e P22 também apontaram a atuação institucional como sendo uma competência técnica/prática importante para o perfil do psicólogo escolar, o que permite uma mudança de foco na atuação do individual para o coletivo. P9 destaca a necessidade de desenvolver essa competência profissional e "Conseguir sair do foco só do aluno, de conseguir desenvolver mais a assessoria com o professor, por mais que seja por meio de formação, de oficina, que acho que isso já vai mostrar pra ele que não é só aquilo" (P9). Para a participante P22 é importante

Desenvolver competências mesmo, porque aqui a gente tem que entrevistar, aqui a gente tem que avaliar, aqui a gente tem que intervir, aqui a gente tem que sugerir, aqui a gente tem que dar oficinas, a gente tem que dar palestras, e aqui a gente é solicitado e demandado o tempo todo (P22).

Interessante observar, na fala de P22, que a escola e outros profissionais já demandam do psicólogo uma ação de caráter institucional, expressa por meio de oficinas e da ocupação de outros espaços formativos e interventivos, saindo do foco do estudante. Para atender a essas "novas" demandas, cabe ao psicólogo desenvolver as competências profissionais necessárias que, nesse caso específico, articulam-se a uma atuação coletiva dentro da instituição educacional. A partir do exposto, percebe-se que os psicólogos reconhecem as possibilidades de atuação no âmbito institucional, mesmo que ainda não sejam ações integralmente planejadas para esse fim.

De acordo com Dazzani (2010), o objetivo da atuação do psicólogo escolar "deve ser a de fazer com que as relações institucionais, demandas sociais, expectativas dos estudantes e dos outros atores educacionais sejam explicitadas, compreendidas e enfrentadas diretamente" (p. 373). Existem desafios a serem vencidos para que a atuação institucional se efetive como uma prática reconhecida pelos próprios psicólogos e pelos profissionais que compõem a escola. Souza et al. (2014) afirmaram que o psicólogo deve ser capaz de assumir as demandas colocadas nos espaços educativos, atuando de forma coletiva e nas relações que constituem o universo escolar (p. 51).

Marinho-Araujo (2014a) propôs um modelo de atuação institucional que compreende as ações de mapeamento institucional, escuta psicológica, assessoria ao trabalho coletivo e acompanhamento do processo de ensino e aprendizagem. Essa forma de atuação, apesar de separada em dimensões, representa um processo com características dinâmicas, sistemáticas e participativas, que se interrelacionam na prática do psicólogo escolar.

O mapeamento institucional, aqui destacado por se relacionar ao indicador atuação institucional e coletiva, compreende a observação, investigação, reflexão e análise do contexto em todas as suas dimensões e considera a complexidade das relações e da própria instituição escolar. Marinho- 
Araujo (2014a) afirmou que o mapeamento institucional "é uma ação histórica que acompanha, dinamicamente, todas as formas de atuação do psicólogo escolar" (p. 164). Apesar da importância dos registros formais no cotidiano da escola, o mapeamento não se restringe à utilização de documentos para a sua realização, utilizando-os para a atualização das informações, compreensão das dificuldades, reformulações e avanços ocorridos na escola (p. 164).

Marinho-Araujo (2014b) ressaltou a necessidade de o psicólogo escolar desenvolver competências para investigar e analisar a instituição escolar, evidenciando, nas práticas educacionais, as possíveis contradições presentes no cotidiano escolar, apontando possibilidades de ressignificação e redirecionamentos para novas ações profissionais (p. 88). O mapeamento institucional prevê, por parte do psicólogo, uma posição ativa nos processos institucionais, considerando-o um profissional que não apenas observa ou analisa o contexto, mas que participa das propostas interventivas a serem feitas na escola.

O indicador domínio da avaliação psicológica foi a terceira competência técnica/prática mais citada pelos psicólogos. A participante P18 considera "Interessante que se tivesse preparação na parte de avaliação psicométrica. É válido, a meu ver. É um instrumento que contribui pra construção da avaliação, não que seja a avaliação" (P18). Esse relato demonstra a visão da psicóloga a respeito da avaliação psicométrica, considerando que ela é importante na prática profissional do psicólogo escolar, porém, por si só, não é suficiente. Da mesma forma considera a psicóloga P9, ao relatar que

Na Secretaria você tem que ter um bom domínio da avaliação psicométrica, porque é uma coisa que é cobrada, que é esperada. (...) É um instrumento que é privativo do psicólogo, então como vou ser avessa àquilo... não sou a favor de rotular, de ser somente isso, por isso que faço de toda forma pra não ser somente isso. Quando alguém vem falar, eu falo que não é assim essa questão da avaliação, não se remete só aos testes (P9).

A participante P9 reconhece que a avaliação psicológica é uma competência profissional exclusiva do psicólogo, devendo este profissional apropriar-se dessa prática. Assim como a participante P18, considera que a avaliação psicométrica ou a utilização de testes psicológicos não são as únicas formas ou procedimentos para a realização dessa ação profissional, mas que ainda é exigido do psicólogo, no contexto escolar, esse tipo de trabalho. O perfil profissional do psicólogo da EEAA, previsto na OP/2010 (GDF, 2010), orienta-o a

diversificar os instrumentos de coleta de dados, considerando o que se quer avaliar, o tipo de informações que se pretende obter e as decisões a tomar, para não só obter informações sobre as causas das dificuldades e das necessidades dos alunos, mas, sobretudo, compreender os processos de aprendizagem. (GDF, 2010, p. 106).

A diretriz contida na OP/2010 (GDF, 2010) corrobora as informações do Conselho Federal de Psicologia (CFP) que, por meio da Cartilha sobre Avaliação Psicológica, define esse procedimento como 
um processo técnico e científico realizado com pessoas ou grupos de pessoas que, de acordo com cada área do conhecimento, requer metodologias específicas. Ela é dinâmica e constituise em fonte de informações de caráter explicativo sobre os fenômenos psicológicos, com a finalidade de subsidiar os trabalhos nos diferentes campos de atuação do psicólogo, dentre eles, saúde, educação, trabalho e outros setores em que ela se fizer necessária. Trata-se de um estudo que requer um planejamento prévio e cuidadoso, de acordo com a demanda e os fins aos quais a avaliação se destina. (CFP, 2013, p. 13).

Compreende-se, a partir dessa definição, que essa competência técnica não se limita, no campo educacional, à aplicação de testes psicológicos ou de outros instrumentos psicométricos. Destaca-se que a avaliação psicológica "é dinâmica e constitui-se em fonte de informações de caráter explicativo sobre os fenômenos psicológicos" (CFP, 2013, p. 13), pois, considerando a complexidade e dinamicidade desses fenômenos, exigem-se do psicólogo escolar competências técnicas e práticas que o levem a melhor averiguar, entender e correlacionar o contexto e as relações nele estabelecidas. Para Mitjáns Martínez (2010) a concepção de avaliação psicológica acerca das dificuldades escolares vem se modificando ao longo do tempo, antes entendida como o diagnóstico de um momento específico e alheio ao contexto em que as dificuldades se expressavam. A autora compreende a necessidade de considerar os espaços relacionais e o importante papel do professor nesse processo de avaliação, destacando o aspecto qualitativo e processual dessa avaliação (p. 44).

Ao referir-se ao processo de avaliação e identificação de alunos superdotados, Gonçalves \& Fleith (2014) discutem a necessidade de o psicólogo escolar promover uma avaliação mais abrangente e multidimensional, que leve em conta a multiplicidade de fatores e fontes de informações. As autoras citam, por exemplo, a utilização de vários instrumentos, tais como testes, escalas, inventários e produções, bem como o contato com o próprio sujeito, professores, colegas de turma e familiares. Dazzani (2010) ressalta que o psicólogo deve buscar novas maneiras de conduzir o processo avaliativo, compreendendo a história escolar do sujeito como um processo que, como tal, deve ser investigado. A OP/2010 (GDF, 2010) orienta que as técnicas, recursos, estratégias e instrumentos de avaliação dos processos psicológicos "precisam buscar a capacidade do estudante, analisando o processo de ensino e de aprendizagem, as condições oferecidas para tanto e, principalmente, ter um compromisso sobre a importância dos resultados da avaliação para a carreira escolar do estudante.” (GDF, 2010, p. 68).

Na proposta de avaliação e intervenção às dificuldades de aprendizagem elaborada por Neves (2011), é reforçada a importância da escola como espaço que possibilita o desenvolvimento humano dentro de uma construção histórica e social (p. 184). A autora considerou a necessidade de ampliar a compreensão acerca das causas das dificuldades escolares, não apenas como uma expressão de características individuais do aluno, mas considerando aspectos relacionados ao professor e ao contexto escolar como um todo (p. 181). Ao propor o modelo do PAIQUE ${ }^{13}$, a autora destacou que o psicólogo

\footnotetext{
${ }^{13}$ Procedimentos de Avaliação e Intervenção das Queixas Escolares e Níveis de Intervenção (GDF, 2010).
} 
escolar deve iniciar suas intervenções dentro da instituição escolar, privilegiando o trabalho com o professor e outros profissionais da escola. Neves (2011) ressalta que, ao iniciar a intervenção psicológica por quem formulou a demanda, no caso, o professor, o psicólogo possibilita um espaço de escuta, atrelando o atendimento do aluno às ações do professor e às demais atividades desenvolvidas na escola.

O perfil profissional do psicólogo escolar deve contemplar o domínio técnico e prático do procedimento de avaliação psicológica, em uma perspectiva dinâmica, relacional e contextualizada, que considere as dimensões do aprender e do ensinar, além de ampliar o olhar para as potencialidades do estudante, principalmente quando é um sujeito de queixa escolar. O psicólogo, ao propor formas de avaliação psicológica, precisa analisar as causas das queixas como resultado da relações e interações ocorridas na escola, envolvendo professores, a equipe escolar, pais e o próprio aluno, visando compreender as dificuldades enfrentadas no processo de escolarização (Facci, Eidt \& Tuleski, 2006; Facci, Tessaro, Leal, Silva \& Roma, 2007).

$\mathrm{O}$ indicador de competência técnica e prática capacidade de organização foi citado por 18 psicólogos. As entrevistadas P23 e P1 refere-se à dificuldade de organização dentro da escola, destacando a importância de desenvolver essa competência profissional. Para ela,

A pessoa tem que ser muito organizada e isso não sou muito, mas tenho tentado. Porque, em uma escola só, é muita informação, muitas salas, muita gente, e a pessoa tem que ser muito organizada (...), registrar as coisas e tal, e com uma iniciativa para pensar nos projetos e levar à frente $(\mathrm{P} 23)$.

Uma coisa que é importante que ainda não comentei é a questão da organização, a questão da facilidade de registro. O psicólogo precisa ter isso. É uma habilidade a questão de saber registrar, mesmo, tudo o que acontece, de fazer um registro coerente de tudo o que acontece (P1).

Nesses relatos, percebe-se que as psicólogas relacionam a utilização de anotações em suas atividades à capacidade de organização do trabalho, destacando importante característica do perfil profissional.

Em termos de registros de atividades, como componente do indicador capacidade de organização, a OP/2010 (GDF, 2010) recomenda que os profissionais que compõem a EEAA organizem as informações levantadas e analisadas durante o mapeamento institucional e nas demais ações realizadas, "de forma a materializar e valorizar o trabalho que está sendo realizado, assim como para subsidiar a organização de um Plano de Atuação das EEAA, que contemple as características e necessidades manifestadas pelo contexto educacional" (p. 96). A capacidade de organização do seu trabalho compõe, assim, parte do perfil profissional a ser desenvolvido pelo psicólogo escolar, como competência técnica que favorece o melhor desenvolvimento das ações profissionais, tais como a otimização do tempo e dos espaços, o planejamento das atividades, o controle das ações profissionais 
que permitem o estabelecimento de rotinas que atendam aos objetivos da EEAA. Para a participante P21, que atua de forma itinerante nas escolas, o psicólogo

Precisa de mais organização porque são duas realidades bem diferentes; às vezes, parece que, quando chega na escola, desliga a outra. O próprio registro das atividades... porque tem que registrar tudo, porque são milhares de alunos, um monte de professores e não dá pra lembrar se você não tiver essa coisa mais organizada, de registrar. Até planejar o que você vai fazer quando chegar na escola (P21).

As falas dos psicólogos P1, P21 e P23 destacaram a capacidade de organização como uma competência técnica do psicólogo escolar, principalmente pelo fato de serem necessárias ações organizativas em sua rotina de trabalho. Marinho-Araujo (2003) afirmou que os conhecimentos técnicos e práticos deveriam estar articulados aos conhecimentos teóricos e conceituais e, como exemplo dessa formulação, destacou a organização e a sistematização do trabalho como saberes técnicos importantes para que os psicólogos atuem na realidade de forma intencional e planejada.

A partir das discussões realizadas, é possível organizar uma síntese das entrevistas dos psicólogos escolares com relação às competências técnicas e práticas, foram discutidos os principais indicadores dessas competências como úteis à formação do perfil profissional do psicólogo escolar que atua na EEAA:

- Desenvolvimento da escuta psicológica - capacidade de observar, compreender e analisar os sujeitos e as relações intersubjetivas que ocorrem na instituição escolar, sensibilizando o olhar para entendê-las e avaliar as demandas individuais e coletivas.

- Apropriação da atuação institucional e coletiva - promoção de intervenções que potencializem o trabalho em equipe, o empoderamento do coletivo na escola e a ressignificação dos papéis e práticas dos sujeitos.

- Domínio da avaliação psicológica - conhecimento dos princípios científicos e técnicos que orientam a avaliação dos processos psicológicos dos diferentes recursos e instrumentos para sua realização no contexto escolar.

- Capacidade de organização - desenvolvimento de ações de planejamento, controle e registro de atividades e o estabelecimento de rotinas profissionais. Otimização do tempo e dos espaços para a realização das ações no contexto escolar. 
Tabela 15

Indicadores de Competências Sociais, Pessoais e Interpessoais

Capacidade de construir espaços de interlocução férteis à atuação profissional. Disponibilidade em avaliar e rever sua própria atuação.

Socialização de saberes, informações e participação nas ações de desenvolvimento de equipe e trabalhos coletivos.

$\mathrm{N}^{\mathrm{o}}$ de psicólogos que citaram o indicador $(n=25)$

Capacidade para construir relacionamentos interpessoais favoráveis à atuação profissional

Empatia

Clareza na comunicação

Valorização do trabalho de equipe

Capacidade de acolher o outro

Tolerância à frustração

Flexibilidade

Sensibilidade

A principal característica de perfil dos indicadores de competências sociais, pessoais e interpessoais apresentada pelos entrevistados refere-se à capacidade de relacionar-se com os demais membros da escola, de criar vínculos e de lidar com os pares nos diversos contextos de ação profissional (indicador capacidade para construir relacionamentos interpessoais favoráveis à atuação). A participante P13 destaca a importância de se ter "Manejo nas relações interpessoais. Eu acho que toda aquela formação básica da Psicologia, o observar, o ouvir, o entender as questões que não estão tão emergentes, tão claras, entender esse "não dito", como funcionam as relações de poder" (P13). Para o entrevistado P20, faz-se necessário ter "Abertura pra aceitar o que é diferente, (...) facilidade de lidar com essa diversidade" (P20). De forma mais ampla, referendando a característica de perfil esperada para o psicólogo escolar, a OP/2010 (GDF, 2010) assinala que o profissional deve desenvolver uma "sensibilidade para integrar, nos processos relacionais, saberes e conhecimentos, ouvindo o outro, respeitando diferentes pontos de vista, abrindo-se para o novo, disponibilizando conquistas pessoais em prol de projetos coletivos" (p. 86). Importante observar que os trechos de fala das participantes indicam que os psicólogos buscam relacionar-se com o outro com o objetivo de estimular o desenvolvimento de vínculos interpessoais exigidos à atuação profissional. Para Marinho-Araujo (2010a), o desenvolvimento de competências relacionais exige do psicólogo mais que processos intuitivos para compreender e atuar sobre essa dinâmica, mas a capacidade de 
Observar esta realidade para mapear espaços, tempos, fazeres, crenças, concepções e dinâmicas, desenvolver sensibilidade de escuta dos discursos institucionais e das "vozes da escola", provocar a re-significação das demandas e criar novos espaços para interlocução e circulação de falas e discursos dos sujeitos. (p. 27).

A autora destacou, ainda, que a construção e apropriação de sentidos e significados compartilhados na escola são influenciadas pelas relações sociais vivenciadas pelos sujeitos, em um processo interdependente de constituição do individual e do social (p. 27). O desafio que surge, então, para o psicólogo escolar, é a do desenvolvimento de um perfil que considere as múltiplas relações existentes na escola e o seu papel mediador perante essa diversidade de pessoas e contextos interativos.

A participante P13 considera que suas competências pessoais e interpessoais estão em desenvolvimento e destaca a relação com a pedagoga com a qual trabalha ao mencionar que

Quando a gente fala de competência ou características pessoais e interpessoais é nesse sentido mesmo daquilo que você já se observa: eu consigo no meu trabalho com as pessoas na escola, no coletivo, com a minha pedagoga... tal coisa eu já faço, é importante na minha atuação, e, tal coisa, eu acho que é importante desenvolver ainda (P13).

$\mathrm{Na}$ relação com o pedagogo que atua na mesma EEAA e outros profissionais da escola, tanto competências de ordem técnica, quanto interpessoal são necessárias à atuação do psicólogo escolar, que deve pensar sua prática de forma transdisciplinar, privilegiando a troca de saberes a partir de seus conhecimentos profissionais, com o objetivo de desenvolver os processos de decisão, reflexão e intervenção (Chagas-Ferreira, 2014).

Outra característica de perfil citada pelos participantes foi a empatia, a capacidade de colocarse no lugar do outro. Os participantes citaram esse indicador em suas falas, mostrando que essa competência social e interpessoal é importante na atuação profissional: "Tem que ter habilidade para lidar com o outro, é muito difícil e você tem que entender (...) eu acho que entra muito a empatia" (P2); "Você se colocar no lugar do outro, desenvolver essa empatia. Então, acho que isso é algo que vai fazer com que também essas relações se tornem até mais saudáveis" (P10).

Para o participante P11, o desenvolvimento da empatia relaciona-se à capacidade do psicólogo de ser flexível, ao afirmar que "Inicialmente vejo essa coisa da flexibilidade, do sair do lugar, da empatia, de me colocar muito no lugar do outro, seja ele aluno, professor, diretor ou pai" (P11). A opinião de P11 abre espaço para a compreensão das vozes institucionais (Marinho-Araujo, 2010a), tanto na perspectiva de se colocar no lugar do outro, quanto de ouvir a si mesmo, as próprias contradições e dilemas. O profissional pode evidenciar as discordâncias entre as práticas educativas e as demandas dos sujeitos, destacando as possíveis incoerências entre os discursos formais e as práticas instituídas (Marinho-Araujo, 2005; Mitjáns Martínez, 2009). O exercício da empatia não pode ficar restrito, unicamente, à compreensão do que sentem ou pensam os sujeitos; ao buscar entender essas motivações, expectativas e escolhas, o psicólogo deverá mobilizar a reflexão e a problematização das práticas educativas, articulando espaços para interlocução e desenvolvimento dos atores educacionais. 
Observa-se, na Tabela 5, que foi citado por 11 participantes o indicador de perfil clareza na comunicação como uma importante competência do exercício profissional do psicólogo. A participante P11 considera que a "A comunicação é o primeiro passo. Como vai acontecer, de diversas maneiras e checar isso... Porque, muitas vezes, essa comunicação acontece, mas será que foi realmente entendido? Então checar se houve a recepção do que eu disse" (P11). Nesse relato, a psicóloga enfatiza a necessidade da comunicação no ambiente profissional ser clara, sendo necessária a checagem junto aos parceiros de trabalho para verificação das informações e sentidos compreendidos na escola. Para Vygotsky (1993, 2007), o processo de comunicação é uma relação mediada por sistemas simbólicos, cujos significados são compartilhados dentro de uma determinada cultura. Nos processos comunicativos que se desenvolvem na prática do psicólogo escolar, além dos aspectos objetivos, faz-se necessário apreender as expectativas, as necessidades, os interesses, os sentidos compartilhados na dinâmica escolar, nem sempre explicitados de forma objetivada e consciente pelos sujeitos. A clareza na comunicação implica, para o psicólogo, no entendimento do papel mediador da linguagem na relação com o outro e de como essa mediação possibilita o desenvolvimento das funções psicológicas superiores dos sujeitos.

A participante P23 entende que a possibilidade de se comunicar é uma forma de:

Colocar as minhas contribuições, poder permitir que o fluxo de comunicação aconteça. Uma grande dificuldade que acontece nessa escola, e talvez em muitas, é a comunicação. Então, a pessoa fala o que quer e o outro entende outra coisa, e a coisa não flui; então criam-se barreiras e aí a comunicação não flui (P23).

No relato dessa psicóloga, compreende-se a importância dessa competência para o perfil profissional do psicólogo escolar, pois a comunicação é uma ferramenta que facilita o entendimento e as ações no trabalho ou pode, de forma contrária, ser um elemento dificultador das relações e objetivos institucionais. O psicólogo, por seu um profissional que estuda e analisa os processos intersubjetivos e relacionais, pode mediar espaços de interlocução entre os profissionais e demais integrantes da escola, conforme relataram Patias, Monte Blanco e Abaid (2009). As autoras expuseram a experiência da intervenção de psicólogas escolares frente a um grupo de professores e gestores, que apresentavam dificuldades de comunicação. As psicólogas propuseram a criação de espaços de reflexão com esses profissionais para discussão das questões que dificultavam as relações e o trabalho na escola, e foram observadas melhorias na qualidade das interações e no desenvolvimento das competências comunicativas desses atores.

A OP/2010 (GDF, 2010) retrata esse indicador de competência social, pessoal e interpessoal ao informar que o psicólogo escolar deve ter "disponibilidade para socializar saberes, promover a circulação de informações, estimular a participação coletiva e o diálogo em equipes profissionais e multiprofissionais, compartilhando metas e objetivos comuns" (GDF, 2010, p. 86). O exercício das competências definidas na OP/2010 (GDF, 2010), relacionadas à capacidade comunicativa, deve ser buscado pelos profissionais e desenvolvido nas relações diárias com os outros membros da escola, 
objetivando a socialização de saberes, percepções, significados e impressões dos fatos cotidianos que marcam a prática escolar. Para Vygotsky (2007), "O uso de meios artificiais - a transição para a atividade mediada - muda, fundamentalmente, todas as operações psicológicas, assim como o uso de instrumentos amplia de forma ilimitada a gama de atividades em cujo interior as novas funções psicológicas podem operar" (p. 55). Compreende-se, assim, o importante papel das interações sociais no desenvolvimento psicológico dos sujeitos, onde as palavras são empregadas como meio de comunicação, que potencializam o desenvolvimento humano e social.

Sintetizando os indicadores de competências sociais, pessoais e interpessoais que podem ser úteis à formação do perfil profissional do psicólogo escolar, tem-se:

Capacidade para construir relacionamentos interpessoais favoráveis à atuação profissional construção de relações profisssionais e de espaços de interlocução com os diversos atores educacionais, desenvolvendo ações coletivas e a socialização de conhecimentos que contribuam para alcançar objetivos comuns.

Empatia - capacidade de se colocar no lugar do outro e entender as motivações, expectativas e pontos de vista dos seus pares.

Clareza na comunicação - Diálogo objetivo e claro com os profissionais, famílias e estudantes da instituição escolar, compartilhando experiências e informações para o desenvolvimento do trabalho. Elaboração de estratégias diversificadas para a construção de relações comunicativas que favoreçam o entendimento entre os sujeitos.

\section{Tabela 16}

Indicadores de Competências Éticas e Estéticas

Sensibilidade em considerar a singularidade de cada situação, levantando questionamentos reflexivos e críticos sobre decisões, posturas e ações. Compromisso político com a profissão e com a atuação profissional. Habilidade para potencializar a imaginação, perspicácia, percepções e $\mathrm{N}^{\mathrm{o}}$ de psicólogos que citaram o indicador sentidos como processos psicológicos favoráveis à prática profissional. $(n=25)$

Responsabilidade com o uso do sigilo

Respeito aos atores educacionais

Criatividade

Responsabilidade profissional 
A partir da sistematização na Tabela 6, serão comentados, a seguir, os principais indicadores sinalizados pelos entrevistados para caracterizar as competências éticas e estéticas que podem compor o perfil profissional do psicólogo escolar nas EEAA da SEDF: criatividade; responsabilidade com o uso do sigilo; respeito aos atores educacionais.

Em termos de competências estéticas, percebe-se que há uma dificuldade, por parte dos participantes, no entendimento desse conceito e no reconhecimento de suas ações relacionadas a essa questão, além de não conseguirem conceituar e exemplificar essa categoria. Por outro lado, há clareza por parte de uma das psicólogas entrevistadas quando afirma que

A forma de você se posicionar no mundo vai dizer muita coisa, ninguém faz nada despretensiosamente. A forma como me apresento, estou falando algo de mim, desde a forma como eu organizo meu espaço físico, como me apresento fisicamente e até como me porto, me posiciono, me exponho $(\mathrm{P} 20)$.

No comentário da psicóloga notam-se características importantes do perfil profissional do psicólogo escolar, especificamente quando relaciona suas ações à forma como impacta as pessoas, seja por sua apresentação física, seja pela maneira de comportar-se e colocar-se nas situações de trabalho. Outro aspecto levantado pela participante é que essas ações não são despretensiosas, ou seja, devem ser feitas com intencionalidade, visando afetar os outros atores educacionais.

Quando questionada sobre quais competências estéticas são necessárias à atuação profissional, a participante P23 relatou que "Tem a ver com a prática de todo profissional e, na verdade, independente do psicólogo estar na escola, é uma questão de uma presença, de chamar atenção e de fluir mais na sua prática." (P23). Assim também compreende a participante P19, quando afirma que

A gente precisa ter cuidado desde a forma como você se veste, pois existe uma expectativa. A gente precisa ter o respeito por quem vai atender; não é porque você está na escola que você vem de qualquer maneira, minimamente tem que estar com uma apresentação. (...) Você é tão estético, seu posicionamento, que já vai ser reconhecido por tal (P19).

A fala dessas participantes ganha respaldo no trabalho de Marinho-Araujo (2003), que afirma que a competência estética mobiliza a capacidade de "construir uma presença e um estilo pessoal coerente, condizente e adequado a cada contexto profissional" e "de usar e de compor, de forma harmônica e agradável, o uso de recursos sensoriais, motores, cognitivos, comportamentais e afetivos." (p. 124). A competência estética não envolve, apenas, recursos ambientais e organizacionais em si mesmos, mas elementos do próprio profissional, que impactam as pessoas e os contextos em que se faz presente.

Para Marinho-Araujo (2007), é importante que o psicólogo escolar desenvolva competências estéticas, compreendidas como a "capacidade de potencializar a imaginação, a perspicácia, a fantasia e a criatividade como processos psicológicos favoráveis à atuação no contexto escolar” (p. 73). Essas competências desenvolvem-se com a mobilização de recursos imaginativos, novas formas de interação com a realidade e sensibilidade nas mediações (Mendes, 2011). Existe uma premente necessidade de 
construção das competências estéticas, pouco exploradas e estudadas na formação do psicólogo escolar e na sua prática profissional. Segundo Mitjáns Martínez (2009), faz parte do desenvolvimento profissional do psicólogo o compromisso com a mudança, com a criatividade e com a inovação (p. 176).

$\mathrm{O}$ indicador criatividade aparece na fala de seis participantes, que relacionam esse processo psicológico à resolução de situações práticas do cotidiano profissional. A participante P3 considera "criativo você inventar novas situações pra resolver um determinado problema. É algo que eu preciso, nessas situações-problema: conseguir enxergar outras possibilidades." (P3). O participante P25 assinala a ideia de que o processo criativo pode ser desenvolvido diariamente em sua prática profissional, ao dizer que "você tem que ter criatividade, e é diária, não adianta. Você é muito surpreendido diariamente." (P25). A participante P13 compreende que "Você é criativo no dia a dia, nas questões mínimas, até na sua casa, na sua família, nas relações. É a questão de solucionar problemas, questões" (P13). Na OP/2010 (GDF, 2010) não há menção diretamente relacionada à capacidade criativa do psicólogo escolar, porém o documento assinala que esse profissional deve desenvolver, em seu perfil profissional, a "facilidade em buscar alternativas de resolução de problemas, por meio de habilidades comunicativas e cooperativas" (GDF, 2010, p. 86).

A função imaginativa ou criativa, para Vygotsky (1987), está relacionada às experiências, necessidades e interesses do sujeito em que se expressam e na relação deste com o meio sociocultural, cujas influências na concretização da imaginação criadora são apontadas como fatores importantes para a compreensão do processo criativo. Para Vygotsky (1987)

A imaginação, como base de toda a atividade criadora, se manifesta por igual em todos os aspectos da vida cultural, possibilitando a criação artística, científica e técnica. Neste sentido, absolutamente tudo o que nos rodeia e que foi criado pela mão do homem, todo o mundo da cultura, em diferenciação ao mundo da natureza, tudo é produto da imaginação e da criação humana, baseados na imaginação. (p. 4).

O processo criativo, como função psicológica superior, não aparece de repente, pois, segundo Vygotsky (1987), é fruto das experiências anteriores do sujeito, em que os elementos que as compõe são recombinados e ressignificados para a formação de um todo novo. Para o autor, mobilizar o antigo com o novo é uma das formas de atividade criadora no ser humano.

A partir das elucidações de Vygotsky (1987), compreende-se que a criatividade não deve ser entendida como manifestação, apenas, de habilidades ou competências práticas, visando à resolução de problemas, conforme relatado pelos participantes da pesquisa. A manifestação criativa relaciona-se a outros processos psicológicos do sujeito e guarda estreita relação com o desenvolvimento cultural que, no caso desse trabalho, focalizou uma de suas expressões, que é o contexto profissional dos psicólogos escolares. Compreendendo o espaço de trabalho, na perspectiva histórico-cultural, como dinâmico e dialético, o sujeito-psicólogo precisa mobilizar diversos processos psicológicos para a realização de suas práticas profissionais, sendo a criatividade um de seus elementos. 
Em uma pesquisa correlata ao tema em questão, Campolina e Mitjáns Martínez (2013) discutiram o conceito de inovação, sendo apresentado como "um conjunto de ações de implementação de novidades nos processos educativos e nas formas de gestão escolar que dependem de elementos favoráveis para o seu desenvolvimento" (p. 325). Ao realizarem um estudo de caso em uma escola pública do município de São Paulo, as autoras identificaram fatores potencializadores de inovação, destacando-se, em particular, a participação da comunidade e o enfrentamento, progressivo, dos problemas vivenciados pela instituição escolar.

Campolina e Mitjáns Martínez (2013) avaliaram que os aspectos históricos e contextuais e a efetiva participação dos atores educacionais possibilitaram a promoção da inovação na realidade da comunidade escolar, expressando-se nas dimensões interativa, comunicativa e motivacional dos sujeitos. Um fator essencial apontado foi a intencionalidade nas ações realizadas pelo grupo gestor e por professores, que objetivaram a implementação de mudanças e mobilização da comunidade frente às situações problemáticas que enfrentavam. Nesse aspecto, caberia pensar o papel do psicólogo escolar atuando conjuntamente com esses atores escolares e contribuindo com seus saberes e competências específicos, a fim de ser mais um agente de transformação social, individual ou de grupos. Como reflexão acerca do papel do psicólogo em contextos similares ao relatado na pesquisa, poderia se indagar que competências estéticas seriam necessárias, aliadas às outras competências profissionais, para que fossem possibilitadas situações para o desenvolvimento de projetos inovadores.

A discussão acerca da criatividade deve ser um tema recorrente em diversas disciplinas do curso de Psicologia, possibilitando ao futuro psicólogo o desenvolvimento dessa competência profissional, pautada em parâmetros científicos e eticamente recomendáveis (Campos \& Largura, 2000; Fleith, 2001). A criatividade é vista como um recurso fundamental, sejam quais forem os contextos, pois permite ao sujeito agir de forma inovadora frente aos desafios, dificuldades e impasses da vida profissional e pessoal (Alencar, Galvão \& Fleith, 2009; Alencar \& Fleith, 2010; Alencar, Fleith, Boruchovitch, \& Borges, 2015).

Em relação aos indicadores de competências éticas, apontados pelos psicólogos entrevistados, são relacionados quase que exclusivamente ao conhecimento e ao uso do Código de Ética Profissional. Dentre os 25 psicólogos entrevistados, 11 citaram responsabilidade com o uso do sigilo como a principal competência ou ação que deve ser observada no campo ético, o que pode demonstrar, ainda, uma forte relação desse conceito com as concepções e práticas da psicologia clínica.

Ao considerar, na postura ética, a responsabilidade com o uso do sigilo profissional, a participante P6 relatou que "É bem complicado, porque a gente mexe com questões muito importantes e claro que a gente tem o nosso código de ética, tem coisa que a gente não pode conversar" (P6). Para a participante $\mathrm{P} 2$

A questão ética é fundamental, não tem como você discutir. É a ética do sigilo, compreender aquele pai, ter empatia, se colocar no lugar do outro, de saber o que falar e porque está falando aquilo. A ética é tudo isso (P2). 
A participante P12, referindo-se ao indicador responsabilidade com o uso do sigilo no acompanhamento do processo de ensino e aprendizagem dos estudantes, relatou que na sua prática essa ação "É uma questão ética, vamos preservar essa criança. São coisas que você tem que construir e aí tem que se policiar. Essas competências éticas precisam ser continuamente renovadas, construídas" (P12).

Considerando que o Código de Ética Profissional do Psicólogo é um forte balizador de ações, comportamentos e práticas profissionais, nos diversos contextos onde acontecem, apreende-se da fala das participantes, para além do que está previsto nesse documento, que existe uma preocupação real com o bem-estar e com a dignidade dos estudantes, familiares e demais membros da comunidade escolar. Na fala da participante P12, destaca-se sua compreensão de que a competência ética não é definitiva, não está pronta, e que necessita ser renovada nas práticas do psicólogo, pela dinamicidade do contexto escolar e dos próprios sujeitos em desenvolvimento.

A OP/2010 (GDF, 2010) prevê, entre as tarefas desenvolvidas pelos profissionais das EEAA, a utilização de um relatório de avaliação e intervenção educacional, no qual são registradas informações acerca dos estudantes, da escola e de ações realizadas pelo psicólogo escolar e pedagogo das EEAA. Na diretriz desse serviço, orientou-se, com base em princípios éticos e técnicos, que o psicólogo escolar tivesse cuidado em relação aos "deveres do profissional nas suas relações com a pessoa atendida, ao sigilo profissional, às relações com a justiça e ao alcance das informações, identificando riscos e compromissos em relação à utilização das informações presentes nos documentos” (p. 109). É ressaltada na OP/2010 a ideia de que os documentos, como relatórios e registros, devem considerar a natureza dinâmica, complexa e não definitiva da realidade escolar, de forma a não cristalizar percepções e observações acerca dos sujeitos.

Para P11, a ação ética se mostra no sigilo das informações recolhidas em sua prática profissional; porém, essa participante também citou que essa característica está presente nas relações interpessoais estabelecidas dentro da escola e no exercício correto da profissão, podendo ser relacionada ao indicador respeito aos atores educacionais. Ela considera que

Essa coisa mesmo do que é o nosso papel, do fazer e não fazer, do não fazer a coisa do atendimento clínico, do cuidado com a nossa escuta, das coisas que estou escutando do aluno, do pai, pra quem vou repassar isso. Até ao escrever o relatório, que informações são importantes, como elas estão escritas, para que isto não seja exposto... Eu vejo mais nesse sentido. Essa ética como membro, como ator da escola, (...) e aí é nessa coisa das relações interpessoais, fortalecer como grupo, essa coisa ética de eu não passar por cima do outro (P11).

A participante $\mathrm{P} 24$, ainda em referência ao indicador respeito aos atores educacionais, destacou que "Acho que a ética é isso. Ser profissional e desenvolver o trabalho respeitando o trabalho do outro, o trabalho dos professores" (P24). 
O respeito aos atores educacionais, expresso pelas participantes como um indicador de competência ética, indica uma preocupação com as singularidades e, ao mesmo tempo, pluralidade dos sujeitos e do contexto escolar. A prática do respeito pode ser entendida, a partir das opiniões das entrevistadas, tanto na forma como o psicólogo age, conversa e se relaciona com as pessoas no cotidiano escolar, quanto à maneira como lida com a própria profissão, com o exercício correto das atividades e funções para as quais foi chamado a intervir. Nesse sentido, o respeito do psicólogo pelos outros passa pelo respeito a si mesmo, às suas convicções e ao cumprimento de seus deveres profissionais junto àqueles que compartilham de suas ações na escola.

Para Vectore (2010), o psicólogo escolar deveria cumprir um importante papel na "constituição de um ser humano solidário, flexível, respeitoso com as diferenças e apto a conviver em uma sociedade plural" (p. 57). A autora considerou que a consolidação de uma prática competente, no sentido do respeito à condição humana, requer o contínuo aprofundamento teórico-metodológico por parte do psicólogo, colaborando para a educação e desenvolvimento dos sujeitos.

Sant'Ana (2011), ao analisar o papel do psicólogo no processo de inclusão escolar, destacou a importância de serem consideradas as opiniões de todos os sujeitos envolvidos nas ações inclusivas. A reflexão acerca das dificuldades percebidas e a construção de estratégias para a resolução desses entraves, permitiriam ao psicólogo colaborar para que "os princípios inclusivos do respeito e atendimento à diversidade humana" (p. 15) fossem, de fato, efetivados na realidade prática.

Essas concepções acerca da ação do psicólogo escolar nos contextos educacionais refletem a preocupação com os sujeitos, que se constituem nas relações diversas ocorridas, mas, também, denotam um compromisso com intervenções para a comunidade escolar como um todo. Marinho-Araujo (2010b), analisando as contribuições do psicólogo, seu processo de formação crítica e ressignificação de concepções acerca do mundo, afirmou que esse profissional deveria desenvolver um "compromisso com o coletivo, a justiça social e com uma ética do respeito, da tolerância e da solidariedade” (p. 31). Esse compromisso, segundo a autora, deveria ter vinculação com posturas profissionais críticas e com transformações éticas e ideológicas pautadas na visão histórico-cultural dos sujeitos.

Finalizando, como síntese das entrevistas dos psicólogos, foram relacionados os principais indicadores de competências éticas e estéticas destacados pelos participantes e que compõem o perfil profissional do psicólogo escolar:

- Responsabilidade com o uso do sigilo - Privacidade e discrição na prática profissional, resguardando informações dos sujeitos que possam vir a criar situações discriminatórias, preconceituosas ou que exponham suas fragilidades.

- Respeito ao atores educacionais - tolerância e consideração aos demais integrantes da instituição escolar, às suas funções e características, compreendendo o contexto escolar como um espaço que privilegia a pluralidade e singularidade dos sujeitos. 
- Criatividade - Mobilização de processos psicológicos diversos, com destaque para os recursos estéticos que favoreçam a disseminação de práticas flexíveis e imaginativas, de forma inovadora. 


\section{Capítulo 6}

\section{Considerações finais}

Esta pesquisa apresenta contribuições para a área de Psicologia Escolar, especificamente em relação ao trabalho desenvolvido por psicólogos escolares das Equipes Especializadas de Apoio à Aprendizagem da SEDF. Entende-se que este estudo pode colaborar para a identificação e construção do perfil profissional do psicólogo a partir dos indicadores analisados.

Esse perfil foi compreendido, nesse trabalho, como um conjunto de conhecimentos, competências, habilidades, características pessoais, valores, percepções e construções subjetivas constituídos historicamente e que, aliados às características particulares da profissão e ao momento histórico e cultural em que vive o psicólogo, caracterizam a prática desse profissional (Marinho-Araujo, 2007). Essa compreensão de perfil fundamenta-se nos pressupostos da Psicologia Histórico-Cultural, na medida em que considera a dinamicidade do desenvolvimento humano, social e cultural dos sujeitos, bem como das instituições das quais são parte integrante.

As demandas sociais e institucionais dirigidas ao psicólogo escolar têm requerido desse profissional uma formação mais ampla e uma atuação mais consciente de seu papel, que contemple diversas competências profissionais em seu exercício. O contexto escolar, que por um lado apresenta contradições e desafios à prática do psicólogo, por outro tem permitido o desenvolvimento de ações profissionais que considerem a complexidade desse cenário e a oportunidade de consolidação da atuação profissional.

O estudo do perfil do psicólogo escolar mostra-se importante por aprofundar conhecimentos acerca das características profissionais esperadas para a atuação no contexto educativo, aspirando compreender como o profissional mobiliza "conhecimentos e saberes, da ciência e da experiência, em processos de construção e reconstrução de competências, visando se instrumentalizar para uma atuação ampliada a um coletivo profissional e a um cenário complexo" (Marinho-Araujo, 2014, p. 173). Criar um espaço de interlocução com os profissionais possibilitou a reflexão acerca das competências exigidas ao psicólogo, estimulando-os à ressignificação de suas práticas.

Os objetivos da pesquisa consistiram no mapeamento das características para a construção do perfil do psicólogo escolar das Equipes Especializadas de Apoio à Aprendizagem e na investigação das competências necessárias à atuação na SEDF. Inicialmente, foi estabelecido contato com os coordenadores intermediários da EEAA para explicação da proposta de pesquisa e solicitação da divulgação para os psicólogos de cada Coordenação Regional de Ensino. Após convite realizado pelo pesquisador, aceitaram colaborar com esse estudo e participar da pesquisa 25 psicólogos escolares que atuavam nas Equipes Especializadas de Apoio à Aprendizagem. Foram realizadas entrevistas individuais com os participantes, visando investigar suas percepções, concepções e práticas relacionadas ao perfil do psicólogo que atua na EEAA. A entrevista, realizada por meio de um roteiro 
semiestruturado, contemplou questões relacionadas à caracterização, formação e atuação dos participantes, focalizando o perfil e as competências profissionais do psicólogo escolar.

As análises das respostas à entrevista com os psicólogos estabeleceram uma zona de significados e sentidos acerca das competências profissionais desenvolvidas pelos participantes, bem como de outras possibilidades de atuação possíveis à construção do perfil desejável para o trabalho desenvolvido na EEAA. Os entrevistados tinham por referência as orientações expressas na OP/2010 (GDF, 2010), que é o documento norteador da atuação do psicólogo escolar da EEAA e que sugere, além dos conhecimentos históricos, teóricos e metodológicos, um perfil a ser desenvolvido pelo psicólogo que ingressa no serviço. Esse perfil prevê a mobilização de diversas competências profissionais que, quando colocadas em ação, direcionam a atuação do psicólogo para a "ressignificação das concepções dos atores da instituição educacional, especialmente no que se refere à compreensão de como ocorrem a aprendizagem e o desenvolvimento" (GDF, 2010, p. 85).

Ao mapear as características para a construção do perfil do psicólogo escolar das EEAA e as competências necessárias à atuação desse profissional, foi possível identificar e organizar os indicadores a partir das considerações dos psicólogos participantes. Esse mapeamento permitiu a elaboração do resumo a seguir.

Tabela 17

Principais indicadores de perfil profissional dos psicólogos escolares das EEAA

Indicadores de competências teóricas, científicas e metodológicas

\begin{tabular}{ll}
\hline \multicolumn{1}{c}{ Indicador } & \multicolumn{1}{c}{ Definição } \\
\hline $\begin{array}{l}\text { Domínio da psicologia do } \\
\text { desenvolvimento humano }\end{array}$ & $\begin{array}{l}\text { Conhecimento das teorias psicológicas relacionadas ao } \\
\text { processo de desenvolvimento humano e sua relação com as } \\
\text { práticas de escolarização, ensino e aprendizagem. }\end{array}$ \\
\hline $\begin{array}{l}\text { Apropriação da abordagem histórico } \\
\text { cultural do desenvolvimento } \\
\text { psicológico }\end{array}$ & $\begin{array}{l}\text { Estudo dos pressupostos teórico-metodológicos da } \\
\text { abordagem histórico cultural do desenvolvimento e sua } \\
\text { aplicação ao campo da Educação. }\end{array}$ \\
\hline $\begin{array}{l}\text { Compromisso com o estudo e } \\
\text { formação continuada }\end{array}$ & $\begin{array}{l}\text { Desenvolvimento, com responsabilidade e compromisso, } \\
\text { de ações regulares e permanentes de estudo e } \\
\text { aperfeiçoamento profissional. }\end{array}$ \\
\hline
\end{tabular}

Indicadores de competências técnicas e práticas

\begin{tabular}{ll}
\hline \multicolumn{1}{c}{ Indicador } & \multicolumn{1}{c}{ Definição } \\
\hline $\begin{array}{l}\text { Desenvolvimento da escuta } \\
\text { psicológica }\end{array}$ & $\begin{array}{l}\text { Capacidade de observar, compreender e analisar os sujeitos } \\
\text { e as relações intersubjetivas que ocorrem na instituição } \\
\text { escolar, sensibilizando-se para entendê-las de forma }\end{array}$ \\
\hline
\end{tabular}


contextualizada. Interpretar e avaliar as demandas individuais e coletivas.

Promoção de intervenções que potencializem o trabalho em

Apropriação da atuação institucional e coletiva equipe, a leitura institucional dos processos e demandas, o empoderamento dos sujeitos no coletivo na escola e a ressignificação dos papéis e práticas profissionais.

Conhecimento dos princípios científicos e técnicos que orientam a avaliação dos processos psicológicos, bem como dos diferentes recursos e instrumentos para sua realização no contexto escolar.

Desenvolvimento de ações de planejamento, controle e registro de atividades e o estabelecimento de rotinas profissionais. Otimização do tempo e dos espaços para a realização das ações no contexto escolar.

Indicadores de competências pessoais, sociais e interpessoais

Indicador

Capacidade para construir relacionamentos interpessoais favoráveis à atuação profissional

Empatia

Clareza na comunicação
Definição

Construção de relações profissionais e de espaços de interlocução com os diversos atores educacionais, desenvolvendo ações coletivas e a socialização de conhecimentos que contribuam para alcançar objetivos comuns.

Capacidade de se colocar no lugar do outro e entender as motivações, expectativas e pontos de vista dos seus pares.

Diálogo objetivo e claro com os profissionais, famílias e estudantes da instituição escolar, compartilhando experiências e informações para o desenvolvimento do trabalho. Elaboração de estratégias diversificadas para a construção de relações comunicativas que favoreçam o entendimento entre os sujeitos.

Indicadores de competências éticas e estéticas

Indicador

Responsabilidade com uso do sigilo

Respeito aos atores educacionais
Definição

Privacidade e discrição na prática profissional, resguardando informações dos sujeitos que possam vir a criar situações discriminatórias, preconceituosas ou que exponham suas fragilidades.

Tolerância e consideração em relação aos demais integrantes da instituição escolar, às suas funções e características, compreendendo esse contexto como um 
espaço que privilegia a pluralidade e singularidade dos sujeitos.

Mobilização de processos psicológicos diversos, com

Criatividade destaque para os recursos estéticos que favoreçam a disseminação de práticas flexíveis e imaginativas, de forma inovadora.

Os resultados gerais da pesquisa, sintetizados na Tabela 17 e discutidos no capítulo anterior, permitiram as seguintes conclusões:

1. Os psicólogos reconheceram a necessidade de aprofundar estudos e dominar os conhecimentos referentes à Psicologia do Desenvolvimento, relacionando-os às práticas educativas e ao processo de desenvolvimento dos demais membros da comunidade escolar.

2. Os participantes identificaram a premência da apropriação da abordagem histórico-cultural do desenvolvimento psicológico, como fundamento teórico-metodológico para a atuação nas EEAA, em consonância à OP/2010 (GDF, 2010).

3. O estudo e a formação continuada foram apontados como importantes indicadores do perfil profissional, pois os psicólogos constataram que se encontram em um processo contínuo de construção profissional.

4. Os participantes entrevistados consideraram o desenvolvimento da escuta psicológica como um dos principais indicadores de competências técnicas e teóricas para o exercício profissional nas EEAA.

5. A atuação institucional e coletiva foi apontada pelos participantes como ação fundamental a ser desenvolvida pelo psicólogo das EEAA, caracterizando uma competência do seu perfil profissional.

6. O domínio da avaliação psicológica foi destacado como importante indicador do perfil profissional do psicólogo que atua no contexto escolar.

7. O desenvolvimento do relacionamento interpessoal pelos psicólogos também foi identificado como indicador do perfil, na medida em que contribui para a criação de vínculos na escola e favorece a atuação profissional.

8. A capacidade de empatia no cotidiano escolar, enquanto característica do perfil profissional do psicólogo escolar, possibilita, na visão dos participantes, a compreensão das relações institucionais e o trabalho com os diversos atores.

9. A competência da comunicação é um importante indicador de perfil do psicólogo, por favorecer a inserção e participação do profissional nos espaços institucionais.

10.A responsabilidade com o uso do sigilo e o respeito aos demais participantes da instituição escolar foram os principais indicadores de competências éticas assinaladas pelos psicólogos, 
o que pode indicar um compromisso com seus pares e com a própria prática profissional. No entanto, essas informações foram consideradas ainda escassas para uma compreensão detalhada do aspecto ético na condução profissional, indicando a necessidade de maior estudo e compreensão das competências éticas, como parte do perfil profissional do psicólogo escolar e de suas implicações no campo profissional.

11. A criatividade foi definida pelos psicólogos como uma habilidade ou competência prática, evidenciando que eles ainda não se apropriaram da compreensão desse construto como indicador de importante processo psicológico superior, que se relaciona a outras dimensões psíquicas do sujeito para favorecer, entre outros aspectos, a expressão de competências estéticas.

A partir das reflexões apontadas pela produção científica da área, pela OP/2010 das EEAA (GDF, 2010) e pelas análises e discussões realizadas pelo pesquisador, foi possível concluir que a identificação das competências do psicólogo escolar não é uma novidade. Diversos autores, conforme discutido no Capítulo 1, já evidenciaram práticas e recursos profissionais que poderiam ser desenvolvidos e utilizados pelo psicólogo; porém, foram diminutos os trabalhos que relacionaram essas características e atividades para o desenvolvimento de competências à construção de um perfil profissional.

Na realização das entrevistas, percebeu-se que os psicólogos encontravam-se familiarizados com os termos perfil e competências profissionais, não causando estranheza aos participantes as questões relacionadas a esses temas. Infere-se que essa aproximação conceitual tenha ocorrido devido ao conhecimento da OP/2010 (GDF, 2010) e das orientações formuladas nesse documento, além do estudo de produções científicas da área, particularmente os trabalhos de Marinho-Araujo (2003, 2005, 2014), amplamente difundidos na SEDF.

As informações recolhidas nas entrevistas indicaram que os entrevistados tinham clareza acerca do perfil esperado para o psicólogo escolar da EEAA, pois não há confusão quanto aos papéis e funções que deveriam ser desenvolvidas por este profissional no contexto escolar. Isso aponta para uma construção identitária do psicólogo na rede pública do DF, em consonância com a literatura científica e com as orientações explicitadas na OP/2010 (GDF, 2010). Nos relatos dos entrevistados, apreende-se, também, que eles reconhecem que não desenvolveram totalmente o perfil esperado para a atuação, mas tinham certa clareza do que ainda precisam construir e, principalmente, identificaram algumas competências profissionais já consolidadas em suas práticas.

O estudo permitiu verificar que os psicólogos reconhecem e atestam a OP/2010 (GDF, 2010) como uma diretriz segura e coerente para o desenvolvimento do perfil profissional, além de apresentar orientações teóricas e metodológicas que direcionam a atuação do psicólogo escolar. Observou-se, ainda, que os participantes não questionam a legitimidade e necessidade da OP/2010 (GDF, 2010) enquanto documento que regulamenta o trabalho desenvolvido nas EEAA. 
A principal constatação de que os entrevistados reconhecem a OP/2010 (GDF, 2010) e suas diretrizes, diz respeito ao entendimento de que o psicólogo escolar deve privilegiar a atuação institucional. Ainda que existam opiniões sobre as dificuldades de trabalhar institucionalmente, os psicólogos já compreendem a importância, o alcance e as possibilidades que essa atuação permite, cabendo o desenvolvimento de competências para a sua consolidação.

A OP/2010 das EEAA (GDF, 2010) tem inspirado a prática dos psicólogos escolares e colaborado para uma atuação mais reflexiva e pautada no perfil profissional sugerido por essa diretriz. Entende-se a necessidade de maior aprofundamento e apreensão dos pressupostos teóricosmetodológicos, além do desenvolvimento de competências profissionais já previstas na OP/2010 (GDF, 2010). Por outro lado, o reconhecimento da importância das diretrizes definidas nesse documento, não garante que os psicólogos escolares exerçam, de fato, intervenções coadunadas às concepções e proposições definidas na $\mathrm{OP} / 2010$.

Alguns trabalhos (Barbosa, 2008; Chagas \& Pedroza, 2013; GDF, 2010; Libâneo, 2015; Marinho-Araujo, Neves, Penna-Moreira \& Barbosa, 2011; Neves, 2001; Penna-Moreira, 2007; Silva, 2015) destacaram que a Psicologia Escolar no DF está na vanguarda em relação às políticas públicas educacionais brasileiras. A atual pesquisa confirma essa constatação, ao reconhecer que a presença do psicólogo escolar na rede pública de ensino do Distrito Federal está fortemente amparada pela legislação, por documentos que subsidiam a inserção e atuação desse profissional na SEDF e por profissionais que, mesmo que não tenham entrado para o serviço com o preparo adequado, estão se esforçando para tal. Como todo processo histórico e social, a construção e a legitimação da Psicologia Escolar na SEDF foram marcadas por um movimento de lutas e de conquistas e, ainda hoje, são necessárias ações políticas e coletivas para novos avanços.

Diante das reflexões apontadas na literatura e a partir das discussões e dos resultados da presente pesquisa, sugere-se, a seguir, uma proposta de perfil profissional para os psicólogos escolares das Equipes Especializadas de Apoio à Aprendizagem, da Secretaria de Educação do DF:

\section{Indicadores de competências teóricas, científicas e metodológicas}

- Conhecimento dos fundamentos da ciência psicológica.

- Domínio do conhecimento da Psicologia da Aprendizagem e do Desenvolvimento Humano, especialmente a abordagem histórico-cultural.

- Conhecimento acerca da Psicologia Escolar.

- Compromisso com estudo e formação continuada.

- Conhecimento e domínio da OP/2010.

- Conhecimento dos documentos da SEDF. 


\section{Indicadores de competências práticas e técnicas}

- Apropriação da atuação institucional.

- Habilidade na interlocução com a gestão escolar.

- Conhecimento do mapeamento institucional.

- Assessoria ao trabalho docente.

- Desenvolvimento da escuta psicológica.

- Habilidade para condução de reuniões, oficinas e outras atividades coletivas.

- Capacidade de organização.

- Conhecimento sobre técnicas de observação.

- Domínio de técnicas de entrevista.

- Habilidade para coordenar ações no trabalho itinerante.

- Capacidade de elaboração de documentos oficiais relacionados ao serviço.

- Desenvolvimento da análise crítica das práticas pedagógicas e institucionais.

- Domínio da avaliação psicológica.

\section{Indicadores de competências sociais, pessoais e interpessoais}

- Clareza na comunicação.

- Capacidade de trabalhar em grupo.

- Capacidade de falar em público.

- Capacidade de construir relacionamentos profissionais com os demais componentes da escola.

- Desenvolvimento da autocrítica.

- Flexibilidade nas práticas cotidianas.

\section{Indicadores de competências éticas e estéticas}

- Engajamento político na profissão e na instituição.

- Respeito às obrigações do serviço público.

- Respeito às diferenças pessoais e profissionais.

- Postura profissional ética no contexto de trabalho.

- Capacidade de elaborar e apresentar trabalhos organizados e atrativos.

- Comprometimento com o desenvolvimento de processos criativos.

Por compreender o perfil profissional como uma construção histórica e dinâmica, marcado por processos culturais, defende-se a necessidade de revisitar, constantemente, o perfil dos psicólogos escolares da EEAA formulado nessa pesquisa, a fim de verificar as atualizações acerca das concepções, 
dos avanços, das mudanças institucionais e das inovações nas práticas profissionais. Os modelos ou proposições de perfil não devem ser entendidos como cristalizações do fazer profissional, mas serem analisados a partir de cada contexto, considerando as peculiaridades das construções individuais, coletivas e profissionais.

Dentro das perspectivas adotadas nessa pesquisa, que fundamentaram-se na abordagem histórico-cultural e na Psicologia Escolar contemporânea, que defende a atuação institucional do psicólogo, compreende-se que os achados desse trabalho se referem ao momento histórico vivenciado pelos profissionais da EEAA, tal como ela se configura atualmente. Os psicólogos estão construindo a história de si mesmos e do serviço do qual fazem parte, constituindo uma realidade específica por sua singularidade, mas também coletiva pelas contribuições que deixarão na trajetória das EEAA na Secretaria de Educação do DF. Os indicadores de perfil analisados correspondem a essa parte da história desses sujeitos e da instituição, que por seus movimentos constantes, se reelaboram a cada nova investigação.

A proposição de indicadores de perfil profissional dos psicólogos escolares das EEAA pode ser útil para o desenvolvimento das competências desses profissionais, na medida em que permite a ressignificação de suas práticas, concepções e saberes. Esse desenvolvimento profissional é possível a partir do processo de aprimoramento profissional permanente, seja individual ou coletivo, possibilitando a compreensão dos conhecimentos e da atuação instituídos, visando ao entendimento da indissociabilidade entre a teoria e a prática profissional.

Como desdobramento desta pesquisa de mestrado, espera-se que os conhecimentos construídos colaborem com o trabalho desenvolvido pelos participantes desse estudo e também para os demais psicólogos escolares integrantes da Equipe Especializada de Apoio à Aprendizagem da SEDF. Acredita-se que a circulação desses resultados contribuirá para a ampliação teórico-conceitual e metodológica acerca do perfil do psicólogo, impactando o seu olhar sobre as práticas profissionais realizadas no interior das escolas.

Com a intenção de influenciar políticas públicas, entende-se que essa pesquisa pode colaborar para a elaboração e realização de concursos públicos para a Secretaria de Educação do DF e o país, onde estejam previstas, na descrição do cargo, características de perfil do psicólogo escolar. Da mesma forma, considera-se importante, para esse fim, recorrer à literatura contemporânea da área de Psicologia Escolar e às competências profissionais condizentes com a OP/2010 (GDF, 2010).

Espera-se, ainda, que os resultados discutidos nesse trabalho orientem a formação inicial e continuada do psicólogo, colaborando para a reformulação de currículos de cursos de Psicologia ou de cursos de especialização em Psicologia Escolar, orientando a realização de estágios em nível de graduação, influenciando a composição de desenhos formativos que contemplem o estudo do perfil e das competências profissionais do psicólogo escolar. Essa expectativa não se refere, apenas, às instituições públicas ou à Secretaria de Educação do DF, contexto da pesquisa. A intenção do 
pesquisador é que os conhecimentos compartilhados e as discussões fomentadas reverberem, também, em instituições de ensino privado que tenham acesso a este trabalho.

Compreende-se a necessidade da efetivação de um processo de formação continuada, no âmbito da SEDF, que contemple as discussões acerca do perfil e das competências profissionais do psicólogo que atua na EEAA. Existem diversos espaços formativos em que podem ser desenvolvidas essas ações, tais como a EAPE, as reuniões de Coordenação Coletiva das EEAA, os espaços constituídos dentro das unidades escolares, além de outros que possam ser criados para atender a essa necessidade. Para além dos espaços da SEDF, destaca-se o trabalho desenvolvido pelo Laboratório de Psicologia Escolar do Instituto de Psicologia, da UnB, por meio do Projeto de Extensão de Ação Contínua (PEAC) Integração Universidade/Psicologia Escolar e da assessoria aos psicólogos escolares da Secretaria de Educação do DF. Esse também poderá ser um contexto que se beneficie das contribuições dessa pesquisa, pois o PEAC está intimamente relacionado à história da Psicologia Escolar no DF, por meio do desenvolvimento de ações de formação e de ressignificação de práticas que favorecem o estudo do perfil do psicólogo escolar da SEDF.

No caso específico da EAPE, considera-se esse espaço como privilegiado para o desenvolvimento de estudos, cursos, oficinas, debates e fóruns que tenham por objetivo a compreensão do perfil e das competências do psicólogo escolar. No segundo semestre de 2015, foi realizado, nesse contexto, um curso de formação para 450 profissionais da Equipe, entre psicólogos e pedagogos, que teve por conteúdo principal o estudo, a discussão e o aprofundamento da OP/2010 (GDF, 2010). O curso foi precedido pela formação de formadores que conduziram, em polos localizados em algumas cidades do DF, os debates e as mediações nas aulas programadas para cada semana. Essa formação, ainda que reduzida em função do movimento de greve organizado pelos professores da SEDF, foi avaliada como profícua pelos participantes. Para o primeiro semestre de 2016, está previsto um curso específico para os psicólogos escolares das EEAA; um dos principais objetivos é construir a fundamentação para o aprofundamento do perfil profissional e das especificidades da atuação.

Ao final deste estudo, sugerem-se, para pesquisas futuras, investigações que averiguem, longitudinalmente, quais foram os processos de mudança no perfil sintetizado nesse trabalho em relação aos participantes da pesquisa ou aos demais psicólogos atuantes nas EEAA. Com o decorrer dos anos e considerando os diversos processos de transformação do ser humano e das instituições, seria interessante investigar de que forma o perfil profissional se transformou, que competências foram consolidadas na prática do psicólogo escolar e que outras expectativas foram construídas em relação ao trabalho desenvolvido por esse profissional.

Outra investigação sugerida refere-se à pesquisa acerca do desenvolvimento de outros indicadores de competências que poderão compor o perfil do psicólogo, além dos já sistematizados nessa pesquisa. As investigações futuras poderiam estudar in loco os contextos específicos de atuação dos psicólogos, identificando como os indicadores de competências apresentam-se na prática desses 
profissionais e relacionando-os tanto a essa pesquisa, quanto a outras produções da Psicologia Escolar que enfocam o perfil profissional do psicólogo escolar.

Um aspecto final, e não menos importante, refere-se ao papel do pesquisador neste trabalho de mestrado acadêmico. Ser psicólogo escolar, conhecer a realidade, a dinâmica e as características do objeto em estudo foi, por um lado, um facilitador, pois possibilitou uma melhor interlocução com os psicólogos e uma maior compreensão dos sentidos e significados compartilhados nas entrevistas. Por outro lado, o exercício do distanciamento do objeto investigado, da escuta qualificada teoricamente e do processo reflexivo, necessário diante dos resultados obtidos, forjaram um perfil de pesquisador até então inexistente. Foram muitos aprendizados e ressignificações do próprio investigador acerca da pesquisa e do campo de atuação do psicólogo escolar das EEAA; a materialização desse trabalho é parte desse processo de desenvolvimento acadêmico, mas, principalmente, humano.

Para concluir, destaca-se o importante papel que o psicólogo escolar pode e deve desenvolver no contexto escolar, assumindo um compromisso social com todos os participantes da comunidade escolar. Construir posturas éticas, mediar o desenvolvimento de seus pares, colaborar para ações institucionais e coletivas que visem à conscientização de si e do outro, mobilizar competências profissionais para o correto exercício da profissão - esses são desafios e princípios que devem pautar as ações do psicólogo escolar. 


\section{Referências}

Alencar, E. S., \& Fleith, D. S. (2010). Criatividade na educação superior: Fatores inibidores. Avaliação, $15,2,201-206$.

Alencar, E. S., Galvão, A. C. T., \& Fleith, D. S. (2009). La relación entre creatividad y expertise: Contribuciones teóricas y empíricas. Revista de Psicología, XXVII (1), 55-78.

Alencar, E. S., Fleith, D. S., Boruchovitch, E., \& Borges, C. N. (2015). Criatividade no ensino fundamental: Fatores inibidores e facilitadores segundo gestores educacionais. Psicologia: Teoria e Pesquisa, 31, 1, 105-114.

Almeida, S. F. C. (1999). O psicólogo no cotidiano da escola: Re-significando a atuação profissional. In R. S. L. Guzzo (Ed.), Psicologia Escolar: LDB e educação hoje (pp. 61-72). Campinas: Alínea.

Almeida, S. F. C. (2001). O psicólogo escolar e os impasses da educação: Implicações da(s) teoria(s) na atuação profissional. In Z. A. P. Del Prette (Ed.), Psicologia escolar e educacional: Saúde e qualidade de vida (pp. 43-57). Campinas: Alínea.

Almeida, S. F. C. (Ed.). (2003). Psicologia Escolar: Ética e competências na formação profissional. Campinas: Alínea.

Anache, A. A. (2005). O psicólogo nas redes de serviços de educação especial: Desafios em face da inclusão. In A. Mitjáns Martínez (Ed.), Psicologia Escolar e compromisso social (pp. 115-133). Campinas: Alínea.

Anache, A. A. (2009). O Psicólogo Escolar e o processo de escolarização de pessoas com deficiência intelectual. In C. M. Marinho-Araujo (Ed.), Psicologia Escolar: Novos cenários e contextos de pesquisa, formação e prática (pp. 221-243). Campinas: Alínea.

Andrada, E. G. C. (2005). Focos de intervenção em psicologia escolar. Psicologia Escolar e Educacional, 9(1), 163-165.

Andrade, F. S. B. (2013). Uma práxis em direitos humanos no ensino fundamental: Contribuições da psicologia e da educação (Dissertação de mestrado não publicada). Universidade de Brasília, Brasília.

Antunes, M. A. M. (2008). Psicologia Escolar e Educacional: história, compromissos e perspectivas. Psicologia Escolar e Educacional,12, 2, 469-475.

Aquino, F.S.B., Lins, R.P.S., Cavalcante, L.A., \& Gomes, A. R. (2015). Concepções e práticas de psicólogos escolares junto a docentes de escolas públicas. Psicologia Escolar e Educacional, 19, 71-78.

Araújo, G. M. G. (2006). Implicações do perfil e das concepções dos pedagogos que atuam em equipes multidisciplinares da Secretaria de Estado de Educação do Distrito Federal, no atendimento às queixas escolares (Dissertação de mestrado não publicada). Universidade de Brasília, Brasília.

Asbahr, F. S. F., Martins, E., \& Mazzolini, B. P. M. (2011). Psicologia, formação de psicólogos e a escola: Desafios contemporâneos. Psicologia em Estudo, 16, 1, 165-171. 
Associação Nacional de Pesquisa e Pós-graduação em Psicologia. (2012). Anais do XIV Simpósio de Pesquisa e Intercâmbio Científico. Produção e Divulgação Científica: os desafios da interdisciplinaridade. Belo Horizonte: ANPEPP/UFMG.

Barbosa, R. M. (2008). Psicologia escolar nas Equipes de Atendimento/Apoio à Aprendizagem de Samambaia/DF: Atuação institucional a partir da abordagem por competências (Dissertação de mestrado não publicada). Universidade de Brasília, Brasília.

Barbosa, D. R., \& Souza, M P. R. (2012). Psicologia educacional ou escolar? Eis a questão. Psicologia Escolar e Educacional, 16, 163-173.

Barroco, S. M. S. (2011). Pedagogia histórico-crítica, psicologia histórico-cultural e educação especial: em defesa do desenvolvimento da pessoa com e sem deficiência. In A. C. G. Marsiglia (Ed.), Pedagogia histórico-crítica: 30 anos (pp. 170-196). Campinas: Autores Associados.

Bassedas, E., Huguet, T., Marrodán, M., Oliván, M., Planas, M., Rossell, M., Seguer, M., \& Vilella, M. (1996). Intervenção educativa e diagnóstico psicopedagógico. Porto Alegre: Artes Médicas.

Bisinoto, C., Marinho, C. M., \& Almeida, L. (2011). A atuação da psicologia escolar na educação superior: Algumas reflexões. Revista Portuguesa de Pedagogia, 45-1, 39-55.

Brasil (1998). Plano Nacional de Educação. Projeto de Lei no 4.173, de 1998. Câmara dos Deputados.

Brasil (2012). Documento Orientador Programa Implantação de Salas de Recursos Multifuncionais. Ministério da Educação.

Campolina, L. O., \& Mitjáns Martínez, A. (2013). Fatores favoráveis à inovação: Estudo de caso em uma organização escolar. Revista Psicologia: organizações e trabalho, 13, 325-338.

Campos, A. P. (2001). O Psicólogo Escolar e a Educação Infantil: um olhar sobre a inserção desse profissional nas escolas de Brasília (Dissertação de Mestrado não publicada). Universidade de Brasília, Brasília.

Campos, H. R. (Ed.). (2007). Formação em psicologia escolar: realidades e perspectivas. Campinas: Alínea.

Campos, H. R., \& Jucá, M. R. B. L. (2003). O psicólogo na escola: Avaliação da formação à luz das demandas do mercado. In S. F. C. Almeida (Ed.), Psicologia Escolar: Ética e competências na formação profissional (pp. 37-56). Campinas: Alínea.

Campos, K. C. L., \& Largura, W. A. N. (2000). Criatividade na formação de psicólogos: Percepção de alunos. Psicologia Escolar e Educacional, 4(2), 11-19.

Carvalho-Santos, E. P. (2014). Entraves na construção da leitura e escrita: Subsídios à Psicologia Escolar (Dissertação de mestrado não publicada). Universidade de Brasília, Brasília.

Carvalho, T. O., \& Marinho-Araujo, C. M. (2010). Psicologia Escolar e orientação profissional: Fortalecendo as convergências. Revista Brasileira de Orientação Profissional, 11(2), 219-228.

Chagas, J. C. (2010). Psicologia escolar e gestão democrática: Uma proposta de atuação em escolas públicas de educação infantil (Dissertação de mestrado não publicada). Universidade de Brasília, Brasília. 
Chagas-Ferreira, J. F. (2014). Cibercultura e nativos digitais: Desafios para a atuação do psicólogo escolar. In R. S. L. Guzzo (Ed.), Psicologia escolar: desafios e bastidores na educação pública (pp. 241-259). Campinas: Alínea.

Chagas, J. C., \& Pedroza, R. L. S. (2013). Psicologia escolar e gestão democrática: Atuação em escolas públicas de Educação Infantil. Psicologia Escolar e Educacional, 17, 35-43.

Chiodi, C. S., \& Facci, M. G. D. (2013). O processo de avaliação psicológica no estado do Paraná. Fractal: Revista de Psicologia, 25, 127-144.

Conselho Federal de Psicologia. (2008). Ano da Psicologia na educação: Textos geradores. Brasília: CFP.

Conselho Federal de Psicologia. (2013). Cartilha Avaliação Psicológica. Brasília: CFP.

Costa, A. S., \& Guzzo, R. S. L. (2006). Psicólogo escolar e educação infantil: Um estudo de caso. Revista Escritos sobre Educ., 5, 1, 5-12.

Cruces, A. V. V. (2003). Psicologia e educação: Nossa história e nossa realidade. In S. F. C. Almeida (Ed.), Psicologia Escolar: Ética e competências na formação e atuação profissional (pp.17-36). Campinas: Alínea.

Cruces, A. V. V. (2005). Práticas emergentes em Psicologia Escolar: Nova ética, novos compromissos. In A. Mitjáns Martínez (Ed.), Psicologia Escolar e compromisso social (pp.47-65). Campinas: Alínea.

Cruces, A. V. V. (2010). Professores e pesquisadores em Psicologia Escolar: desafios da formação. In C. M. Marinho-Araujo (Ed.), Em Aberto, 83, 23, 17-35.

Dazzani, M. V. M. (2010). A Psicologia Escolar e a educação inclusiva: Uma leitura crítica. Psicologia Ciência e Profissão, 30, 362-375.

Del Prette, Z.A P. (Ed.). (2001). Psicologia Escolar e Educacional: Saúde e qualidade de vida. Campinas: Alínea.

Del Prette, Z. A. P., \& Del Prette, A. (1996). Habilidades envolvidas na atuação do psicólogo escolar/educacional. In S. M. Wechsler (Ed.), Psicologia Escolar: Pesquisa, formação e prática (pp.127-144). Campinas: Alínea.

Denzin, N. K., \& Lincoln, Y. S. (2006). O planejamento da pesquisa qualitativa: Teorias e abordagens. Porto Alegre: Bookman e Artmed.

Dias, A. C. G., Patias, N. D., \& Abaid, J. L. W. (2014). Psicologia Escolar e possibilidades na atuação do psicólogo: Algumas reflexões. Psicologia Escolar e Educacional, 18, 105-111.

Duarte, R. (2004). Entrevistas em pesquisas qualitativas. Educar, 24, 213-225.

Facci, M. G. D., Eidt, N. M., \& Tuleski, S. C. (2006). Contribuições da teoria histórico-cultural para o processo de avaliação psicoeducacional. Psicologia USP, 17, 99-124.

Facci, M. G. D., \& Souza, M. P. R. (2011). “- O que este menino tem?”: Contribuições do método instrumental de Vigotski para o processo de avaliação psicológica. In C. M. Marinho-Araujo, \& 
R. S. L. Guzzo (Eds.), Psicologia escolar: Identificando e superando barreiras (pp. 77-100). Campinas: Alínea.

Facci, M. G. D., Tessaro, N. S., Leal, Z. F. R. G., Silva, V. G., \& Roma, C. G. (2007). Psicologia histórico-cultural e avaliação psicológica: O processo ensino aprendizagem em questão. Psicologia Escolar e Educacional, 2, 323-338.

Farrell, P. (2009). El papel en desarrollo de los psicólogos escolares y educativos en el apoyo a niños, escuelas y familias. Papeles del Psicólogo, 30, 74-85.

Filter, K. J, Ebsen, S., \& Dibos, R. (2013). School psychology crossroads in America: Discrepancies between actual and preferred discrete practices and barriers to preferred practice. International Journal of Special Education, 28, 1.

Fleith, D. S. (2001). Criatividade: Novos conceitos e ideias, aplicabilidade à educação. Cadernos de Educação Especial, 17, 55-61.

Fleith, D. S. (2009). A contribuição do psicólogo escolar para o desenvolvimento das altas habilidades.

In C. M. Marinho-Araujo (Ed.), Psicologia Escolar: Novos cenários e contextos de pesquisa, formação e prática (pp. 245-264). Campinas: Alínea.

Fleith, D. S. (2011). A política nacional de educação especial na perspectiva da educação inclusiva: Desafios para o psicólogo escolar. In R. S. L. Guzzo, \& C. M. Marinho-Araujo (Eds.), Psicologia Escolar: Identificando e superando barreiras (pp.33-46). Campinas: Alínea.

Flick, U. (2009). Introdução à pesquisa qualitativa. Porto Alegre: Artmed.

Freire, A. N., \& Aires, J. S. (2012). A contribuição da psicologia escolar na prevenção e no enfrentamento do bullying. Psicologia Escolar e Educacional, 16, 55-60.

Freitas, M. T. A. (2002). A abordagem sócio-histórica como orientadora da pesquisa qualitativa. Cadernos de Pesquisa, 116, 21-39.

Giongo, C., \& Oliveira-Menegotto, L. M. (2010). (Des)enlaces da psicologia escolar na rede pública de ensino. Psicologia USP, 21, 859-874.

Gomes, V. L. T. (1999). A formação do psicólogo e os impasses entre a teoria e a prática. In R. S. L. Guzzo (Ed.). Psicologia escolar: LDB e educação hoje (pp. 49-73). Campinas: Alínea.

Gonçalves, F. C., \& Fleith, D. S. (2014). Oportunizando atendimento educacional a alunos superdotados na educação básica. In R. S. L. Guzzo (Ed.), Psicologia escolar: Desafios e bastidores na educação pública (pp. 297-315). Campinas: Alínea.

Gontijo, R. F. (2013). A avaliação no serviço especializado de apoio à aprendizagem: Repercussões no desempenho escolar (Dissertação de mestrado não publicada). Universidade de Brasília, Brasília.

González Rey, F. L. (1999). Psicologia e educação: Desafios e projeções. In O. A. Rays (Ed.), Trabalho pedagógico: Realidade e perspectivas (pp.102-117). Porto Alegre: Sulina.

González Rey, F. L. (2002). Pesquisa qualitativa em psicologia: Caminhos e desafios. São Paulo: Thomson. 
González Rey, F. L. (2005). Pesquisa qualitativa e subjetividade: Os processos de construção da informação. São Paulo: Thomson.

González Rey, F. L. (2010). As configurações subjetivas do câncer: Um estudo de casos em uma perspectiva construtivo-interpretativa. Psicologia: Ciência e Profissão, 30, 328-345.

Governo do Distrito Federal. (2010). Orientação Pedagógica: Serviço Especializado de Apoio à Aprendizagem. Brasília: SEDF.

Governo do Distrito Federal (2013). Portaria $n^{o} 30$ de 29 de janeiro de 2013. DODF, XLIII, 26.

Governo do Distrito Federal (2015a). Censo Escolar. Recuperado de http://www.se.df.gov.br/educacao-df/rede-part-conv/469-censo-escolar-2015.html

Governo do Distrito Federal (2015b). Quantitativo geral do SEAA 2015. Brasília: Subsecretaria de Educação Básica/SEDF.

Governo do Distrito Federal (2015c). Decreto $n^{o}$ 36.828, de 22 de outubro de 2015. DODF, XLIV, 205.

Günther, H. (2006). Pesquisa qualitativa versus pesquisa quantitativa: Esta é a questão? Psicologia: Teoria e Pesquisa, 22, 2, 201-210.

Guzzo, R. S. L. (1996). Formando psicólogos escolares no Brasil: Dificuldades e perspectivas. In S. M. Wechsler (Ed.), Psicologia Escolar: Pesquisa, formação e prática (pp. 63-79). Campinas: Alínea.

Guzzo, R. S. L. (Ed.). (1999a). Psicologia Escolar: LDB e educação hoje. Campinas: Alínea.

Guzzo, R. S. L. (1999b). Novo paradigma para formação e atuação do psicólogo escolar no cenário educacional brasileiro. In R. S. L. Guzzo (Ed.), Psicologia Escolar: LDB e educação hoje (pp. 105-115). Campinas: Alínea.

Guzzo, R. S. L. (2000). Risco e proteção: Busca de indicadores para uma intervenção preventiva. Campinas, Pontifícia Universidade Católica de Campinas.

Guzzo, R. S. L. (2001). Saúde psicológica, sucesso escolar e eficácia da escola: Desafios do novo milênio para a psicologia escolar. In Z.A P. Del Prette (Ed.), Psicologia Escolar e Educacional: Saúde e qualidade de vida (pp. 25-42). Campinas: Alínea.

Guzzo, R. S. L. (2003). Educação para a Liberdade, Psicologia da Libertação e Psicologia Escolar: Uma práxis para a liberdade. In S. F. C. Almeida (Ed.), Psicologia Escolar: Ética e competências na formação profissional (pp. 169-178). Campinas: Alínea.

Guzzo, R. S. L. (2005). Escola amordaçada: Compromisso do psicólogo com este contexto. In A. Mitjáns Martínez (Ed.), Psicologia Escolar e compromisso social (pp.17-29). Campinas: Alínea.

Guzzo, R. S. L. (2008). Psicologia em instituições escolares e educativas: apontamentos para um debate. In Conselho Federal de Psicologia (Ed.), Ano da psicologia na educação: textos geradores (pp. 53-61). Brasília: CFP.

Guzzo, R. S. L. (Ed.). (2014). Psicologia Escolar: Desafios e bastidores na Educação Pública. Campinas: Alínea. 
Guzzo, R. S. L., \& Marinho-Araujo, C. M. (2011). Psicologia Escolar: identificando e superando barreiras. Campinas: Alínea.

Guzzo, R., Mezzalira, A. S. C., Moreira, A. P.G (2012). Psicologia na rede pública de educação: Embates dentro e fora da profissão. Psicologia Escolar e Educacional, 12, 329-338.

Guzzo, R. S. L.; Moreira, A. P. G., \& Mezzalira, A. S. C. (2011). Avaliação Psicossocial: Desafios para a prática profissional nos contextos educativos. Avaliação Psicológica, 10, 163-171.

Helgoth, S., \& Sobansky, R. R. (2008). The roles and functions of school Psychologists: a global perspective. International Journal of Psychology: a Biopsychosocial Approach, 1, 85-98.

Instituto de Pesquisa Econômica Aplicada. (2014). Atlas do desenvolvimento humano nas regiões metropolitanas brasileiras. Brasília: PNUD, FJP.

Jimerson, S. R., Graydon, K., Curtis, M. J., \& Staskal, R. (2007). The international school psychology survey: Insights from school psychologists around the world. In S. R. Jimerson, T. D. Oakland, \& P. T. Farrell (Eds.). The handbook of international school psychology (pp. 453-463). London: Sage.

Jimerson, S. R., Graydon, K., Farrell, P., Kikas, E., Hatzichristou, C., Boce, E., et al. (2004). The International School Psychology Survey: Development and Data from Albania, Cyprus, Estonia, Greece and Northern England, 25, 259-286.

Jimerson, S. R., Graydon, K., Skokut, M., Alghorani, A., Kanjaradze, A., Forster, J., et al. (2008). The International School Psychology Survey: Data from Georgia, Switzerland and the United Arab Emirates, 29, 5-28.

Jimerson, S. R., Graydon, K., Yuen, M., Lam, S.-F., Thurm, J.-M., Klueva, N., et al. (2006). The International School Psychology Survey: Data from Australia, China, Germany, Italy and Russia, 27, 5-32.

Jimerson, S. R., Skokut, M., Cardenas, S., Malone, H., \& Stewart, K. (2008). Where in the World is School Psychology? Examining Evidence of School Psychology Around the Globe. School Psychology International, 29, 131-144.

Jimerson, S. R, Stewart, K., Skokut, M., Cardenas, S., \& Malone, H. (2009). How many school psychologists are there in each country of the world? International estimates of school psychologists and school psychologist-to-student ratios. School Psychology International, 30, 6, 555-567.

Le Boterf, G. (2003). Desenvolvendo a competência dos profissionais. Porto Alegre: Artmed.

Leontiev, A. N. (1978a). O desenvolvimento do psiquismo. Lisboa: Livros Horizonte.

Leontiev, A. N. (1978b). Activity, consciousness, and personality. Englewood Cliffs, NJ: Prentice-Hall.

Leontiev, A. N. (1980). Atividade e consciência. In V. M. Vilhena. Práxis: A categoria materialista de prática social. Vol. II. Lisboa: Livros Horizonte. 
Lessa, P. V., \& Facci, M. G. D. (2009). O psicólogo escolar e seu trabalho frente ao fracasso escolar numa perspectiva crítica. Atas do IX Congresso Nacional de Psicologia Escolar e Educacional. São Paulo: Universidade Presbiteriana Mackenzie.

Libâneo, L. C. (2015). Práticas exitosas em psicologia escolar: Indicadores da atuação na cultura do sucesso (Dissertação de mestrado não publicada). Universidade de Brasília, Brasília.

Madureira, A. F. A., \& Branco, A. U. (2001). A pesquisa qualitativa em psicologia do desenvolvimento: questões epistemológicas e implicações metodológicas. Temas em Psicologia, 9, 63-75.

Maluf, M. R. (2001). O psicólogo escolar e a educação: Uma prática em questão. In Z. A. P. Del Prette (Ed.), Psicologia escolar e educacional: Saúde e qualidade de vida (pp. 59-71). Campinas: Alínea.

Marinho-Araujo, C. M. (1995). As dificuldades de aprendizagem sob o foco das relações interpessoais professor-aluno (Dissertação de mestrado não publicada). Universidade de Brasília, Brasília.

Marinho-Araujo, C. M. (2003). Psicologia Escolar e o desenvolvimento de competências: Uma opção para a capacitação continuada (Tese de doutorado não publicada). Universidade de Brasília, Brasília.

Marinho-Araujo, C. M. (2005). Psicologia Escolar e o desenvolvimento de competências. Boletim Academia Paulista de Psicologia, 25, 73-85.

Marinho-Araujo, C. M. (2007). A psicologia escolar nas diretrizes curriculares: Espaços criados, desafios instalados. In H. R. Campos (Ed.), Formação em Psicologia Escolar: realidades e perspectivas (pp.17-48). Campinas: Alínea.

Marinho-Araujo, C. M. (Ed.). (2009a). Psicologia Escolar: Novos cenários e contextos de pesquisa, formação e prática. Campinas: Alínea.

Marinho-Araujo, C. M. (2009b). Psicologia Escolar na Educação Superior: Novos cenários de intervenção e pesquisa. In C. M. Marinho-Araujo (Ed.), Psicologia Escolar: Novos cenários e contextos de pesquisa, formação e prática (pp. 155-202). Campinas: Alínea.

Marinho-Araujo, C. M. (Ed.). (2010a). Em Aberto, 83, 23. Brasília: INEP.

Marinho-Araujo, C. M. (2010b). Psicologia Escolar: Pesquisa e intervenção. In C. M. Marinho-Araujo (Ed.), Em Aberto, 83, 23, 17-35.

Marinho-Araujo, C. M. (2014a). Intervenção institucional: Ampliação crítica e política da atuação em Psicologia Escolar. In R. S. L. Guzzo (Ed.), Psicologia Escolar: Desafios e bastidores na educação pública (pp.153-175). Campinas: Alínea.

Marinho-Araujo, C. M. (2014b). Psicologia Escolar na educação superior: Desafios e potencialidades. In R. S. L. Guzzo (Ed.), Psicologia Escolar: Desafios e bastidores na educação pública (pp.219239). Campinas: Alínea.

Marinho-Araujo, C. M., \& Almeida, S. F. C. (2003). Psicologia Escolar institucional: Desenvolvendo competências para uma atuação relacional. In S. F. C. Almeida (Ed.), Psicologia Escolar: Ética e competências na formação e atuação profissional (pp.59-82). Campinas: Alínea. 
Marinho-Araujo, C. M., \& Almeida, S. F. C. (2005). Psicologia Escolar: recriando identidades, desenvolvendo competências. In A. Mitjáns Martínez (Ed.), Psicologia Escolar e compromisso social (pp.243-259). Campinas: Alínea.

Marinho-Araujo, C. M., \& Almeida, S. F. C. (2014). Psicologia Escolar: Construção e consolidação da identidade profissional (4. ed.). Campinas: Alínea.

Marinho-Araujo, C. M., \& Neves, M. M. J. N. (2007). Psicologia escolar: perspectivas e compromissos na formação continuada. In H. R. Campos (Ed.), Formação em Psicologia Escolar: Realidades e perspectivas (pp. 69-87). Campinas: Alínea.

Marinho-Araujo, C. M., Neves, M. M. J. N., Penna-Moreira, P. C. B., \& Barbosa, R. M. (2011). Psicologia Escolar no Distrito Federal: história e compromisso com políticas públicas. In R. S. L. Guzzo, \& C. M. Marinho-Araujo (Eds.), Psicologia Escolar: identificando e superando barreiras (pp. 47-76). Campinas: Alínea.

Marinho-Araujo, C. M., \& Rabelo, M. L. (2015). Avaliação educacional: a abordagem por competências. Avaliação, 20, 2, 443-466.

Martín-Baró, I. (1983). La polarización social en El Salvador. ECA, 412, 129-142.

Martín-Baró, I. (1986/2011). Para uma psicologia da libertação. In R. S. L. Guzzo, \& F. Lacerda Jr. (Orgs.). Psicologia social para América Latina: O resgate da psicologia da libertação (pp. 181198). Campinas: Alínea.

Martín-Baró, I. (1996). O papel do psicólogo. Estudos de Psicologia, 2, 7-27.

Mitjáns Martínez, A. M. (2003). O psicólogo na construção da proposta pedagógica da escola: Áreas de atuação e desafios para a formação. In S. F. C. Almeida (Ed.), Psicologia Escolar: Ética e competências na formação e atuação profissional (pp.105-124). Campinas: Alínea.

Mitjáns Martínez, A. M. (Ed.). (2005). Psicologia Escolar e Compromisso Social: Novos discursos, novas práticas. Campinas: Alínea.

Mitjáns Martínez, A. (2007). O psicólogo escolar e os processos de implantação de políticas públicas: atuação e formação. In H. R. Campos (Ed.), Formação em Psicologia Escolar: Realidades e perspectivas (pp. 109-133). Campinas: Alínea.

Mitjáns Martínez, A. M. (2009). Psicologia Escolar e Educacional: compromissos com a educação brasileira. Psicologia Escolar e Educacional (ABRAPEE), 13, 1, 169-177.

Mitjáns Martínez, A. M. (2010). O que pode fazer o psicólogo na escola? In C. M. Marinho-Araujo (Ed.), Em Aberto, 83, 23, 17-35.

Medeiros, L. G. M., \& Aquino, F. S. B. (2011). Atuação do psicólogo escolar na rede pública de ensino: Concepções e práticas. Psicologia Argumento, 29, 227-236.

Mendes, A. C. M. (2011). Oficina lúdica e mediação estética na formação continuada de psicólogos escolares (Dissertação de mestrado não publicada). Universidade de Brasília, Brasília.

Molon, S. I. (2008). Questões metodológicas de pesquisa na abordagem sócio-histórica. Informática na Educação: Teoria \& Prática, 11, 1. 
Moreira, A. P. G., \& Guzzo, R. S. L. (2014). O psicólogo na escola: um trabalho invisível? Gerais: Revista Interinstitucional de Psicologia, 7, 42-52.

Mori, V. D., \& González Rey, F. L. (2011). Reflexões sobre o social e o indivíduo na experiência do câncer. Psicologia \& Sociedade, 23, 99-108.

Nasciutti, F. M., \& Silva, S. M. C. (2014). O processo de ensinar/aprender uma perspectiva crítica em psicologia escolar e educacional. Psicologia em Estudo, 19, 25-37.

Neves, M. M. B. J. (2001). A atuação da psicologia nas equipes de atendimento psicopedagógico na rede pública de ensino do Distrito Federal (Tese de doutorado não publicada). Universidade de Brasília, Brasília.

Neves, M. M. B. J. (2009). A atuação dos psicólogos escolares no Distrito Federal. In C. M. MarinhoAraujo (Ed.), Psicologia Escolar: Novos cenários e contextos de pesquisa, formação e prática (pp. 55-73). Campinas: Alínea.

Neves, M. M. B. J. (2011). Queixas escolares: Conceituação, discussão e modelo de atuação. In R. S. L. Guzzo, \& C. M. Marinho-Araujo (Eds.), Psicologia Escolar: Identificando e superando barreiras (pp.175-192). Campinas: Alínea.

Neves, M. M. B. J., \& Almeida, S. F. C. (2003). A atuação da Psicologia Escolar no atendimento aos alunos encaminhados com queixas escolares. In S. F. C. Almeida (Ed.). Psicologia Escolar: Compromisso ético e competências na formação e atuação profissional (pp. 83-104). Campinas: Alínea.

Novaes, M. H. (1996). Perspectivas para o futuro da Psicologia Escolar. In S. M. Weschler, (Ed.), Psicologia Escolar: Pesquisa formação e prática (pp. 51-60). Campinas: Alínea.

Oakland. T., \& Hatzichristou, C. (2014). Professional preparation in school psychology: A summary of information from programs in seven countries. International Journal of School \& Educational Psychology, 2, 223-230.

Oliveira, M. K. (2002). Vygotsky: aprendizado e desenvolvimento, um processo sócio-histórico. 4. ed. São Paulo: Scipione.

Oliveira, C. B. E. (2007). Psicologia Escolar e a relação família-escola no Ensino Médio: estudando as concepções desta relação (Dissertação de mestrado não publicada). Universidade de Brasília, Brasília.

Oliveira, C. B. E. (2011). A atuação da psicologia escolar na educação superior: proposta para os serviços de psicologia (Tese de doutorado não publicada). Universidade de Brasília, Brasília.

Oliveira, C. B. E., \& Marinho-Araujo, C. M. (2009). Psicologia Escolar: Cenários atuais. Estudos e Pesquisas em Psicologia, 9, 648-663.

Oliveira, C. B. E., \& Marinho-Araujo, C. M. (2013). Práticas contemporâneas de atuação em Psicologia Escolar. Psicologia, Educação e Cultura, 17, 212-236.

Patias, N. D., Monte Blanco, M. H., \& Abaid, J. L. W. (2009). Psicologia Escolar: Proposta de intervenção com professores. Cadernos de Psicopedagogia (UNISA), 7, 42-60. 
Penna-Moreira, P. C. B. (2007). A psicologia escolar nas equipes de atendimento/apoio à aprendizagem da secretaria de estado de educação do distrito federal: entre o verbo e a ação (Dissertação de mestrado não publicada). Universidade de Brasília, Brasília.

Pereira, K. R. C. (2011). Diagnóstico de dificuldade de aprendizagem: Construção, concepção e expectativas (Dissertação de mestrado não publicada). Universidade de Brasília, Brasília.

Petroni, A. P., \& Souza, V. L.T. (2014). Psicólogo escolar e equipe gestora: Tensões e contradições de uma parceria. Psicologia: Ciência e Profissão, 34, 444-459.

Pinto, J. V. (2014). Concepções sobre desenvolvimento e aprendizagem: Um estudo do serviço especializado de apoio à aprendizagem na SEE/DF (Dissertação de mestrado não publicada). Universidade de Brasília, Brasília.

Rodrigues, L. G. (2011). Psicólogo escolar e coordenador pedagógico: uma parceria necessária (Dissertação de mestrado não publicada). Universidade de Brasília, Brasília.

Rossi, T. M. F., \& Paixão, D. L. L. (2003). Significações sobre a atuação do psicólogo escolar. In S. F. C. Almeida (Ed.), Psicologia escolar: Ética e competência na formação profissional. Campinas: Alínea.

Sant'Ana, I. M. (2011). Contribuições da atuação do psicólogo escolar na educação inclusiva: Concepções de professores e diretores. Vertentes, 19, 2.

Sant'Ana, I. M., \& Guzzo, R. S. L. (2014). O psicólogo escolar e o projeto político-pedagógico da escola: Diálogos e possibilidades de atuação. In R. S. L. Guzzo (Ed.), Psicologia Escolar: Desafios e bastidores na educação pública (pp. 85-109). Campinas: Alínea.

Silva, L. A. V. (2015). História, diretrizes, avanços e desafios na Psicologia Escolar no Distrito Federal: As vozes dos psicólogos escolares das Equipes Especializadas de Apoio à Aprendizagem de Ceilândia (Dissertação de mestrado não publicada). Universidade de Brasília, Brasília.

Souza, V. L. T. (2009). Psicologia e compromisso social: Reflexões sobre as representações e a identidade do psicólogo escolar-educacional. Revista Eletrônica de Psicologia e Políticas Públicas, 1, 14-34.

Souza, V. L. T. S., Petroni, A. P., Dugnani, L. A. C., Barbosa, E. T., \& Andrada, P. C. (2014). O psicólogo na escola e com a escola: A parceria como forma de atuação promotora de mudanças. In R. S. L. Guzzo (Ed.), Psicologia escolar: Desafios e bastidores na educação pública (pp. 2754). Campinas: Alínea.

Thielking, M., \& Jimerson, S. R. (2006). Perspectives regarding the role of school psychologists: Perceptions of teachers, principals, and school psychologists in Victoria, Australia. Australian Journal of Guidance and Counselling, 16, 211-223.

Torezan, A. M. (1999). Psicologia Escolar e a nova conjuntura educacional brasileira. In R. S. L. Guzzo (Ed.), Psicologia Escolar: LDB e educação hoje (pp.27-37). Campinas: Alínea. 
Tuleski, S. C., Facci, M. G. D., \& Barroco, S. M. S. (2013). Psicologia histórico-cultural, marxismo e educação. Teoría y crítica de la psicología, 3, 281-301.

Vectore, C. (2010). Perspectivas para a promoção da qualidade na educação infantil: Alguns instrumentos. In C. M. Marinho-Araujo (Ed.), Em Aberto, 83, 23, 17-35.

Vieira, M. M. F., \& Zouain, D. M. (2005). Pesquisa qualitativa em administração: Teoria e prática. Rio de Janeiro: FGV.

Vygotsky, L. S. (1987). La imaginación y el arte en la infancia. Madrid: Akal.

Vygotsky, L. S. (1993). Pensamento e linguagem. São Paulo: Martins Fontes (Texto original publicado em 1934).

Vygotsky, L. S. (1995). Obras Escogidas III. Problemas del desarollo de la psique Madrid: Visor. (Texto original publicado em 1983).

Vygotsky, L. S. (1996). Teoria e Método em Psicologia. São Paulo: Martins Fontes. (Texto original publicado em 1926-1927).

Vygotsky, L. S. (2001). A construção do pensamento e da linguagem. São Paulo: Martins Fontes.

Vygotsky, L. S. (2007). A formação social da mente. São Paulo: Martins Fontes. (Texto original publicado em 1984).

Vygotsky, L. S., Luria, A. R., \& Leontiev, A. N. (1998). Linguagem, desenvolvimento e aprendizagem. São Paulo: Ícone.

Yamamoto, K., Santos, A. A. L., Galafassi, C., Pasqualini, M. G., \& Souza, M. P. R. (2013). Como atuam psicólogos na educação pública paulista? Um estudo sobre suas práticas e concepções. Psicologia: Ciência e Profissão, 33, 794-807.

Wanderer, A., \& Pedroza, R. L. S. (2010). Elaboração de projetos político-pedagógicos: reflexões acerca da atuação do psicólogo na escola. Psicologia Escolar e Educacional, 14, 121-129.

Weschler, S. M. (Ed.). (1996). Psicologia Escolar: Pesquisa formação e prática. Campinas: Alínea. 


\section{Anexos}

Anexo 1 - Parecer consubstanciado do CEP 


\section{INSTITUTO DE CIENCIAS HUMANAS / UNIVERSIDADE DE BRASÍLIA / CAMPUS}

\section{PARECER CONSUBSTANCIADO DO CEP}

\section{DADOS DO PROJETO DE PESQUISA}

Título da Pesquisa: Indicadores do perfil profissional dos psicólogos escolares das Equipes Especializadas de Apoio à Aprendizagem da Secretaria de Educação do DF.

Pesquisador: Leonardo Vieira Nunes

Área Temática:

Versão: 2

CAAE: 41081115.0 .0000 .5540

Instituição Proponente: Instituto de Ciências Humanas/UNB

Patrocinador Principal: Financiamento Próprio

\section{DADOS DO PARECER}

Número do Parecer: 995.713

Data da Relatoria: 27/03/2015

\section{Apresentação do Projeto:}

Trata-se de pesquisa para obtenção do título de Mestre, que consistirá no estudo do perfil profissional dos psicólogos escolares, por meio de entrevistas semiestruturadas e análise documental. Pretende-se entrevistar 28 psicólogos da Secretaria de Educação do DF, das diferentes cidades que compõem do Distrito Federal. Após a análise das informaçōes recolhidas, pretende-se identificar e sugerir as competências profissionais necessárias à atuação no campo da Psicologia Escolar.

\section{Objetivo da Pesquisa:}

Objetivo Primário:

Investigar os indicadores de perfil profissional de psicólogos escolares das Equipes Especializadas de Apoio à Aprendizagem da Secretaria de Educação do DF.

Objetivo Secundário:

1. Mapear as características para a construção dos indicadores do perfil do psicólogo escolar das Equipes Especializadas de Apoio à Aprendizagem da Secretaria de Educação do DF (SEDF).

2. Investigar as competências necessárias à atuação em Psicologia Escolar.3. Identificar os espaços e ações formativas para o desenvolvimento do perfil profissional dos psicólogos escolares das

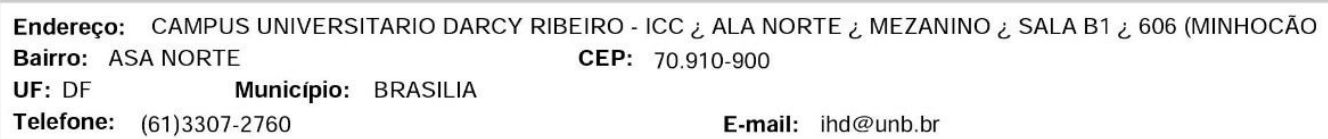




\section{INSTITUTO DE CIENCIAS HUMANAS / UNIVERSIDADE DE BRASÍLIA / CAMPUS}

Continuação do Parecer: 995.713

Equipes Especializadas de Apoio à Aprendizagem da Secretaria de Educação do DF.

Avaliação dos Riscos e Benefícios:

Não são identificados riscos para os participantes da pesquisa e nem para o pesquisador responsável, uma vez que a metodologia prevê apenas a realização de entrevistas com participantes adultos. Este procedimento é apontado pelo pesquisador responsável, inclusive, como um provável benefício aos participantes, que poderão usufruir das sessões de entrevista, como uma oportunidade de reflexão sobre a sua própria ação.

\section{Comentários e Considerações sobre a Pesquisa:}

Trata-se de pesquisa com impacto para as políticas públicas da educação básica no Distrito Federal, com delineamento que abrange de forma interessante todo o serviço de Psicologia Escolar oferecido pela rede pública de ensino

\section{Considerações sobre os Termos de apresentação obrigatória:}

O pesquisador apresenta adequadamente todos os documentos exigidos pelo Sistema CEP/Conep para a realização de pesquisas com seres humanos.

\section{Recomendações:}

Conclusões ou Pendências e Lista de Inadequações:

O projeto de pesquisa apresenta todos os cuidados necessários às pesquisas com seres humanos.

\section{Situação do Parecer:}

Aprovado

Necessita Apreciação da CONEP:

Não

Considerações Finais a critério do CEP: 
Anexo 2 - Termo de Consentimento Livre e Esclarecido 


\section{Termo de Consentimento Livre e Esclarecido}

Você está sendo convidado a participar da pesquisa "Indicadores do perfil profissional do psicólogo escolar das Equipes Especializadas de Apoio à Aprendizagem da Secretaria de Educação do Distrito Federal", de responsabilidade de Leonardo Vieira Nunes, aluno(a) de mestrado do Programa de Pós-graduação em Processos de Desenvolvimento Humano e Saúde, do Instituto de Psicologia, da Universidade de Brasília. O objetivo desta pesquisa é investigar os indicadores de perfil profissional de psicólogos escolares das Equipes Especializadas de Apoio à Aprendizagem da Secretaria de Educação do DF. Assim, gostaria de consultá-lo(a) sobre seu interesse e disponibilidade de cooperar com a pesquisa.

Você receberá todos os esclarecimentos necessários antes, durante e após a finalização da pesquisa, e lhe asseguro que o seu nome não será divulgado, sendo mantido o mais rigoroso sigilo mediante a omissão total de informações que permitam identificá-lo(a). Os dados provenientes de sua participação na pesquisa, tais como questionários, entrevistas ou gravações de áudio, ficarão sob a guarda do pesquisador responsável pela pesquisa.

A coleta de dados consistirá numa entrevista individual, a partir de um roteiro semiestruturado, onde será gravado o áudio para posterior transcrição e análise das informações. Não haverá gravação de vídeo e/ou imagem do(a) participante. É para este procedimento que você está sendo convidado(a)a participar. Sua participação na pesquisa não implica em nenhum risco.

Espera-se com este estudo contribuir para a pesquisa e divulgação do perfil profissional do psicólogo escolar e de estudos relacionados ao tema e para a implementação de políticas públicas com base no perfil profissional dos psicólogos escolares, no âmbito da Secretaria de Educação do DF. Acredita-se, ainda, que oportunizará aos psicólogos escolares um momento de reflexão acerca de suas práticas e das competências necessárias à atuação profissional.

Sua participação é voluntária e livre de qualquer remuneração ou benefício. Você é livre para recusar-se a participar, retirar seu consentimento ou interromper sua participação a qualquer momento. A recusa em participar não irá acarretar qualquer penalidade ou perda de benefícios.

Se você tiver qualquer dúvida em relação à pesquisa, você pode me contatar através do telefone (61) 9226-0913 ou pelo e-mail leovnunes@gmail.com.

A equipe de pesquisa garante que os resultados do estudo serão devolvidos aos participantes por meio comunicação direta e disponibilização da dissertação em formato digital, podendo ser publicados posteriormente na comunidade científica.

Este projeto foi revisado e aprovado pelo Comitê de Ética em Pesquisa do Instituto de Ciências Humanas da Universidade de Brasília - CEP/IH. As informações com relação à assinatura do TCLE ou os direitos do sujeito da pesquisa podem ser obtidos através do e-mail do CEP/IH: cep_ih@unb.br.

Este documento foi elaborado em duas vias, uma ficará com o(a) pesquisador(a) responsável pela pesquisa e a outra com o senhor(a). 
Anexo 3 - Roteiro de entrevista 


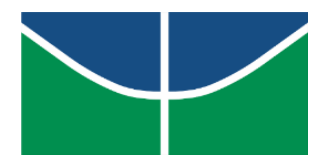

Indicadores do perfil profissional do psicólogo escolar das

Equipes Especializadas de Apoio à Aprendizagem da Secretaria de Educação do DF

Roteiro de Entrevista

1. Caracterização

- Idade

- Gênero

- Ano de conclusão do curso de Psicologia

- Cargo na SEDF

- Tempo de atuação profissional como Psicólogo Escolar na EEAA

- Cidade/regional de atuação

2. Formação inicial

- Na sua graduação em Psicologia, você teve alguma preparação para atuar com Psicólogo Escolar?

- Em que momentos essa preparação ocorreu? (Ex.: Disciplinas, estágios, pesquisas, outros)

3. Formação continuada

- Você participou ou participa de algum tipo de formação continuada em Psicologia Escolar? Cite quais o(s) tipo(s) de formação.

- Caso participasse de uma formação continuada, que temas/assuntos deveriam ser abordados para contemplar a sua atuação profissional?

4. Atuação profissional

- Que atividades você desenvolve como psicólogo escolar da EEAA?

- Na sua opinião, até que pontos essas atividades estão articuladas com a OP?

5. Perfil do Psicólogo Escolar da SEDF

- Quais os conhecimentos teóricos, científicos e metodológicos necessários à atuação nas EEAA?

- Quais os conhecimentos práticos e técnicos necessários à atuação nas EEAA?

- Quais as características pessoais, interpessoais e sociais desejáveis para a atuação nas EEAA?

- Que competências éticas e estéticas e outras são desejáveis à atuação nas EEAA? 